\title{
Basal cell carcinoma, a disease on the increase : implications for treatment and prevention
}

Citation for published version (APA):

Krekels, G. A. M. (1998). Basal cell carcinoma, a disease on the increase : implications for treatment and prevention. [Doctoral Thesis, Maastricht University]. Universiteit Maastricht. https://doi.org/10.26481/dis.19981216gk

Document status and date:

Published: 01/01/1998

DOI:

10.26481/dis.19981216gk

Document Version:

Publisher's PDF, also known as Version of record

\section{Please check the document version of this publication:}

- A submitted manuscript is the version of the article upon submission and before peer-review. There can be important differences between the submitted version and the official published version of record.

People interested in the research are advised to contact the author for the final version of the publication, or visit the DOI to the publisher's website.

- The final author version and the galley proof are versions of the publication after peer review.

- The final published version features the final layout of the paper including the volume, issue and page numbers.

Link to publication

\footnotetext{
General rights rights.

- You may freely distribute the URL identifying the publication in the public portal. please follow below link for the End User Agreement:

www.umlib.nl/taverne-license

Take down policy

If you believe that this document breaches copyright please contact us at:

repository@maastrichtuniversity.nl

providing details and we will investigate your claim.
}

Copyright and moral rights for the publications made accessible in the public portal are retained by the authors and/or other copyright owners and it is a condition of accessing publications that users recognise and abide by the legal requirements associated with these

- Users may download and print one copy of any publication from the public portal for the purpose of private study or research.

- You may not further distribute the material or use it for any profit-making activity or commercial gain

If the publication is distributed under the terms of Article $25 \mathrm{fa}$ of the Dutch Copyright Act, indicated by the "Taverne" license above, 


\section{Basal cell carcinoma, a disease on the increase Implications for treatment and prevention}

Proefschrift

ter verkrijging van de graad van doctor aan de Universiteit Maastricht, op gezag van de Rector Magnificus, Prof. Dr. A.C. Nieuwenhuijzen Kruseman, ingevolge het besluit van het College van Decanen in het openbaar te verdedigen op vrijdag 16 oktober 1998 om 14.00 uur

door

Gertruud Anna Maria Krekels 
Promotor:

Co-promotor:

Beoordelingscommissie:
Prof. dr. H.A.M. Neumann

Dr. R. Hoekzema

Universiteit Maastricht, Faculteit Geneeskunde ISBN 90-9011933-7

The studies in this thesis were made possible by financial support of Zwitsal (Kortmann Intradal), Roc, and Consumenten Bond Nederland.

Printing of this thesis was financially supported by Zwitsal, Delial, Beiersdorf N.V., Vichy, E. Merck Nederland B.V., Nederlandse Cosmetica Vereniging, Novartis Pharma B.V., Medi Nederland B.V., Coloplast B.V., Yamanouchi Pharma B.V., Medireva, Roche Farmaceuticals, Leo Pharamceutical Products B.V., GlaxoWellcome, Galderma, Jansen-Cilag BV, Hoechst Marion Roessel, Schering-Plough B.V., Smith \& Nephew Nederland B.V., Asta Medica B.V., Perstorp Pharma, CS Cosmetique. 
Aan mijn moeder en Roger

Ter nagedachtenis aan mijn vader 


\section{Abbreviations}

$\begin{array}{ll}\text { AK } & \text { Actinic Keratosis } \\ \text { BCC } & \text { Basal cell carcinoma(s) } \\ \text { CHS } & \text { Contact hypersensitivity } \\ \text { CPD } & \text { Cyclobutane pyrimidine dimer(s) } \\ \text { DTH } & \text { Delayed-type hypersensitivity } \\ \text { LC } & \text { Langerhans cells } \\ \text { MBCC } & \text { Multiple BCC } \\ \text { MED } & \text { Minimal erythema dose } \\ \text { MMS } & \text { Molns Micrographic Surgery } \\ \text { NBCCS } & \text { Nevoid Basal Cell Carcinoma Syndrome } \\ \text { NMSC } & \text { Squamous cell carcinoma(s) } \\ \text { SCC } & \text { Sun(screen) protection factor } \\ \text { SPF } & \text { T4 endonuclease V } \\ \text { T4N5 } & \text { Ultraviolet A (315-400 nm) } \\ \text { UVA } & \text { Ultraviolet B (280-315 nm) } \\ \text { UVB } & \text { Ultraviolet C (100-280 mm) } \\ \text { UVC } & \text { Ultraviolet radiation } \\ \text { UVR } & \text { Xeroderma Pigmentosum } \\ \text { XP } & \end{array}$




\section{Contents}

General introduction $\quad 7$

Chapter $1 \quad$ Basal cell carcinoma $(\mathrm{BCC}) \quad 9$

Chapter 2 Pathogenesis of basal cell carcinoma 33

Chapter $3 \quad$ Treatment of BCC with Mohs Micrographic Surgery 45

Chapter $4 \quad$ Keratins in aggressive basal cell carcinoma

$\begin{array}{lll}\text { Chapter } 5 & \text { UV-carcinogenesis } & 69\end{array}$

Chapter $6 \quad$ DNA-protection by sunscreens: Using p53- 85 immunostaining

$\begin{array}{lll}\text { Chapter } 7 & \text { Dissociation between SPF and p53 protection }\end{array}$

$\begin{array}{lll}\text { Chapter } 8 & \text { Sunbeds and p53 } & 107\end{array}$

$\begin{array}{lll}\text { Chapter } 9 & \text { General Discussion } & 119\end{array}$

$\begin{array}{lll}\text { Chapter } 10 & \text { Samenvatting } & 123\end{array}$

Curriculum Vitae

Dankwoord 



\section{General introduction}

This thesis is about the most common cancer in Caucasians: basal cell carcinoma (BCC).

Every one out of six people in the western world will be diagnosed with this cancer sooner or later. The two ways to reduce morbidity (and the rare event of mortality due to this tumor), are improvement of therapy and secondly, even more important: prevention. This thesis will focus on these two items.

$\mathrm{BCC}$ is a frequent cutaneous tumor, often located on the face. The incidence of nonmelanoma skin cancer (basal cell carcinoma and squamous cell carcinoma) is much higher in countries with a high level of exposure to sunlight, such as Australia, and the southern part of the United States. In Australia, where the incidence is highest and these tumors have received greatest attention, the annual incidence in tropical regions approaches 1 per 100 people.

Currently in the Netherlands, an estimated number of $29.000 \mathrm{BCC}$ are diagnosed annually, and the prevalence is steadily increasing. The dramatic increase in nonmelanoma skin cancers in relatively low sunlight areas like the Netherlands, suggests that major prevention programms are needed in areas that are not considered "sunspots".

Research on nonmelanoma skin cancer in humans is important for several reasons.

In the first place non-melanoma skin cancer, the most common type of cancer, is rapidly increasing worldwide. To reduce morbidity and mortality, research should therefore concentrate on ways to improve the treatment of these tumors and focus on skin cancer prevention.

In the second place UV-induced skin cancer can serve as a model for the pathogenesis of cancer in general. Non-melanoma skin cancer is (or should be) a molecular oncologist's dream: the etiological agent, UV radiation, is well defined; it is the most common malignancy in Caucasians; precursor lesions such as actinic keratosis are even more common; obtaining tumor specimens and normal control specimens is as easy as taking a punch-biopsy; the two most common types of skin cancer, BCC and squamous cell carcinoma show marked differences in clinical and biologic behavior; inherited syndromes such as Nevoid Basal Cell Carcinoma Syndrome, exist.

Although some consider $\mathrm{BCC}$ as a relatively benign tumor, $\mathrm{BCC}$ is a true malignant neoplasm. Warren's (1961) four criteria for a malignant tumor are:

1) malignant tumors tend to be anaplastic, i.e, less differentiated than the normal cells from which they are derived.

2) Malignant tumors infiltrate and destroy normal tissue, whereas benign tumors grow by expansion and push aside normal tissue. 
3) Malignant tumors in general grow more rapidly and have higher mitotic counts and/or abnormal mitoses.

4) Malignant tumors have the power of metastasis, whereas benign tumors remain localized.

It now seems clear that malignancies generally arise through the serial accumulation of damage to genes in a single cell. When the collected defects finally free the cell from normal restraints on growth, tumors develop. The discovery that genetic damage lies at the root of eancer does not mean most malignancies stem from the inheritance of seriously flawed genes. The genetic disruptions that transform a normal cell into a malignant one typically arise in the course of living - via complex interactions between carcinogens and the body's systems for contending with them.

Indeed, whether any agent contributes to cancer depends not only on the extent of an individual's exposure but also on the effectiveness of the body's defensive responses responses now known to vary from one individual to another, sometimes profoundly. Of course, an individual's own traits can also influence cancer development, and these characteristics undoubtedly help to explain why a given "dose" of carcinogen will cause only some people to get cancer, whereas others escape the disease.

Interest in cancer of the skin has greatly increased in recent years. Reasons for this increase are manyfold. Skin cancer is the most common malignancy in humans and is clearly related to sun exposure, and more people have increased exposure to natural and artificial sunlight.

Indeed the biggest problem will be convincing the public that excessive UV exposure (by sunlight or sunbeds) is unhealthy!! 
Chapter I

\section{Basal Cell Carcinoma}


Skin cancers can be divided into two major classes: non-melanoma skin cancer (NMSC) and malignant melanoma. Other cancers of the skin include non-epidermal tumors like: lymphomas, fibrous tissue tumors etc. NMSC can be subdivided into two main subclasses: basal cell carcinomas (BCC), by far the most common (skin) cancer in humans, and squamous cell carcinomas (SCC). In the United States, $\mathrm{BCC}$ accounts for about $80 \%$ of skin cancers, SCC for $12 \%$ and malignant melanoma for $5 \%$.

\subsection{Definition of $\mathrm{BCC}$}

Synonyms for basal cell carcinoma are: basal cell epithelioma, ulcus rodens, ${ }^{2}$ rodent ulcer or noli me tangere (touch me not), ${ }^{3}$ basalioma and Jacobs' ulcer. ${ }^{4}$ The name basal cell carcinoma was first published in 1903.5

$\mathrm{BCC}$ is a cutaneous epithelial tumor characterized by nests or sheets of small basaltype cells having a relatively large oval basophilic nucleus. Cell borders are often poorly defined. The peripheral layer of tumor cells in each island is usually arranged like a palisade. Tumor nest are in contact with the epidermis, or there is apparent attachement to the outer root sheath of hair follicles. The term BCC was chosen because of the morphological similarities of the tumor cells to basal keratinocytes: $\mathrm{BCC}$ was thus regarded as a basal cell layer-derived neoplasm. However, based on recent studies on intermediate filaments, ${ }^{\sigma, 7}$ a close relationship between $\mathrm{BCC}$ and the hair follicle may be suggested.

Many theories have been proposed as to the site and cell of origin of the $\mathrm{BCC}{ }^{8,9}$ These have included (1) basal cells of the epidermis, (2) basal cells of the infundibular and outer root sheath of the hair follicle, (3) dormant primordial epithelial germ cells, (4) pluripotential epithelial cells in the basal cell layer that persist throughout life, (5) cells of the pilosebaceous unit, and (6) cells from other appendageal structures.

\subsection{Incidence}

BCC is the most common malignant tumor in humans, and skin cancers currently constitute approximately one third of all diagnosed cancers. ${ }^{10}$ The mortality is low, but due to their high prevalence, $\mathrm{BCC}$ are a significant and costly health problem. The costs of treating NMSC exceeds 500 million dollars per year in the United States." The incidence of NMSC is much higher in countries with a high level of exposure to natural sunlight, ${ }^{12}$ such as Australia and the southern parts of the United States. ${ }^{13.14,15}$ The incidence is increasing worldwide, including in higher latitudes. In Australia, where the incidence is highest and these tumors have received greatest attention, the annual incidence in tropical regions approaches 1 per 100 people. ${ }^{16}$ In the United States, skin cancer is affecting one in every five persons at some time during their life. ${ }^{17.18}$ According to the Skin Cancer Foundation, one in six Americans will develop NMSC during his or her lifetime. BCC represents $75 \%$ of NMSCs and is, therefore, the 
most common malignant disease in the United States ${ }^{19}$ and throughout the world..$^{20}$ Currently in the Netherlands, an estimated number of $29.000 \mathrm{BCC}$ are diagnosed annually, (survey among dermatologists). ${ }^{21}$ The prevalence of skin cancer is increasing in the Netherlands. ${ }^{22,23,24}$ The dramatic increase in non-melanoma skin cancers, in relatively low sunlight areas, suggests that major prevention programmes are needed in areas that are not considered "sunspots". ${ }^{25}$

The incidence of skin cancer may have increased due to changes in sunbathing behavior, and aging and can be further due to decrease in stratospheric ozone. ${ }^{26}$ As the ozone layer principally absorbs UV of wavelengths below $290 \mathrm{~nm}$, reductions in stratospheric ozone levels are likely to result in increased UVB at the earth's surface, with the risk of increased incidence of skin cancer ${ }^{27} \mathrm{~A} 1 \%$ depletion in stratospheric ozone may be expected to increase NMSC, by about $2 \%-4 \%{ }^{28}$ Projections based on current assumptions of chlorine release suggest that a decline will continue into the next century. On the basis of the decrease in ozone over the mid-latitudes, an increase in biologically effective UVR of $4 \%$ to $9 \%$ is expected, depending on the season and geographical location. ${ }^{29}$

\subsection{Morbidity and mortality}

The mortality due to NMSC is relatively low. Despite the rising incidence of NMSC, mortality rates have decreased over the last few decades. ${ }^{30}$ Mortality rates are greater among men compared with women and whites compared with blacks. ${ }^{31}$ Currently, the overall 5-year survival rate is greater than $95 \%$. Cutaneous SCC, which has only onefourth the mortality of malignant melanoma, ${ }^{32}$ accounts for about three-fourths of the deaths attributed to NMSC. ${ }^{33}$

Although $\mathrm{BCC}$ contribute much less to tumor-related deaths than $\mathrm{SCC}$, they may be extremely aggressive and cause significant morbidity with disfigurement, invasion of vital structures, mutilating local destruction, and considerable expense. Especially because $\mathrm{BCC}$ in younger patients show a more aggressive behavior ${ }^{34}$

\subsection{Risk factors for the development of BCC}

Factors associated with an increased risk of $\mathrm{BCC}_{, 3}^{35}$ are presented in table 1.

More than $99 \%$ of persons in whom BCC develop are white; $95 \%$ of the patients are between the age of 40 and 79 years. Slightly more than half of all patients are men. The sex difference has become less pronounced in recent years. This presumably is the result of changes in the dress and lifestyle of women, which has led to a more chronic sun exposure. Increased UV exposure probably also explains why $\mathrm{BCC}$ is no longer rare in young adults. 
Table 1. Factors associated with an increased risk of BCC

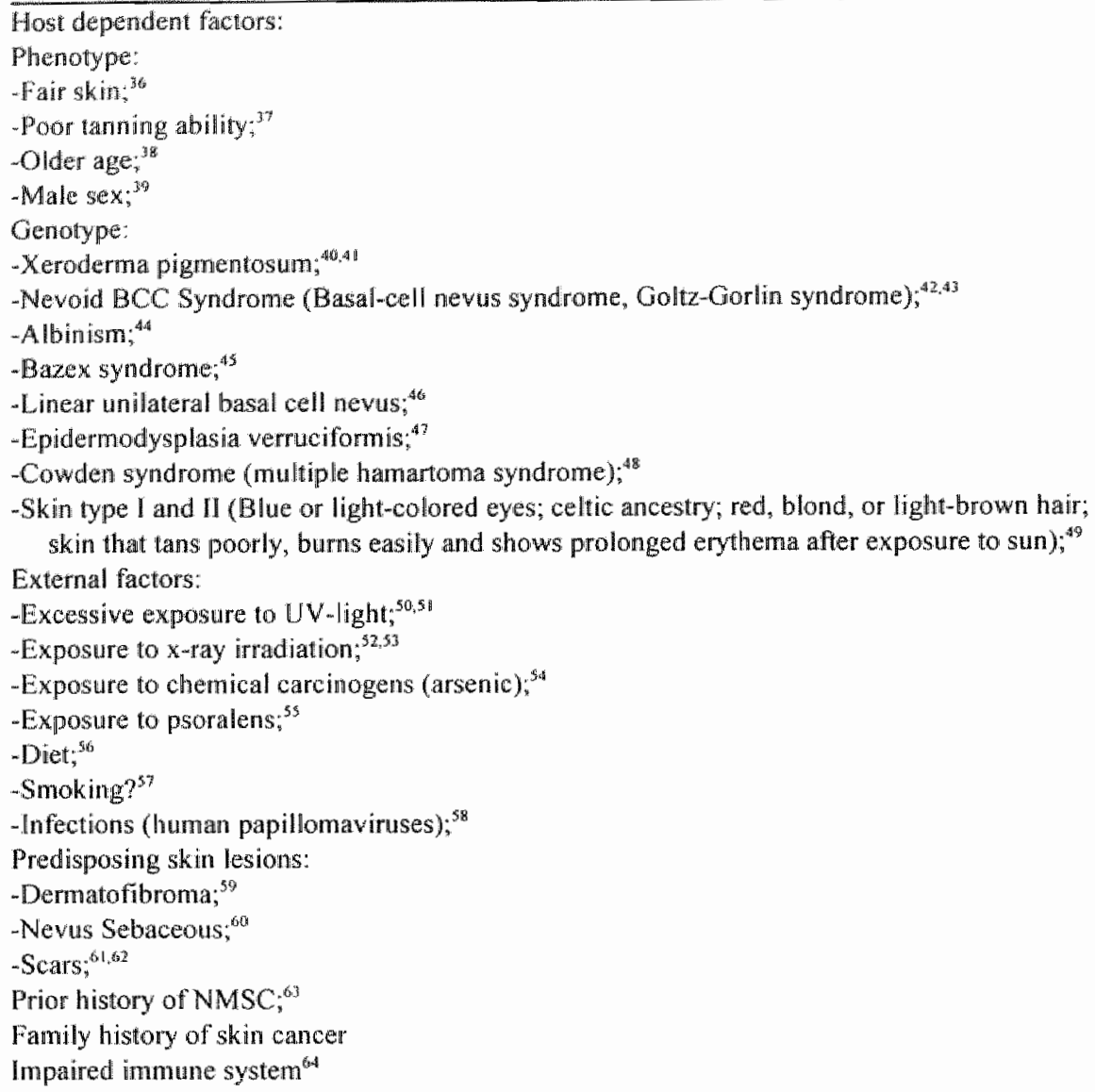

Exposure to UV radiation is a principal cause of BCC (see Chapter 5 UV cancinogenesis), however additional factors nay be involved. ${ }^{65}$ Most iesions occur on skin that is frequently exposed to sunlight. The annual incidence of BCC in Hawail is 692 per 100,000 inhabitants ${ }^{66}$ which is much greater than the annual incidence rate of 10 per 100,000 in lceland ${ }^{67}$ Outdoor workers and people who report frequent outdoor activity have a higher incidence than other persons. ${ }^{6 \&}$ World War II veterans exposed to high intensity sun in the Pacific had a significantly larger number of BCC and SCC than World War II veterans in Europe. ${ }^{69}$

Recent evidence indicates that many patients with skin cancer have an impaired ability to repair DNA damaged by UV radiation, ${ }^{70}$ an inability to stop the cell cycle of a potentially malignant cell, a defect in a tumor suppressor protein, or a defective oncogene. ${ }^{71}$

Reduced repair of UV-induced DNA damage contributes directly to BCC in individu- 
als with prior sunlight overexposure. ${ }^{72}$ Patients with a family history of skin cancer may be at increased risk for inheriting one of these genetic defects. Sun exposure undoubtedly increases the risk even more. ${ }^{73}$

The risk of $\mathrm{BCC}$ varies according to race and ethnic group. For Caucasians, the incidence of these cancers is most strongly associated with age, residence in areas with high levels of ambient UVB radiation and early UV exposure. ${ }^{745} \mathrm{BCC}$ are uncommon in blacks, ${ }^{76,77}$ Asians and Hispanics. ${ }^{787}$ This may be due to the increased protection of the skin afforded by melanin or to other genetical differences. Anong blacks, SCC are more common than BCC and BCC usually occur in sites that have not been exposed to the sun and are often aggressive. ${ }^{3 !}$

Though BCC may also appear in old scars and ulcers, they are more likely to arise within a few weeks or months following a burn or injury to the skin. ${ }^{82}$ This is a classic scenario for welders who develop a BCC in an area where they were burned with a welding spark or a metal chip.

Other factors in addition to UV radiation exposure may play a synergistic role in many BCC. Besides UV radiation, arsenicals, polyaromathic hydrocarbons, and ionizing radiation have been linked to an increased risk of $\mathrm{BCC}{ }^{83}$ Arsenic has been linked to both internal malignancies and the development of extensive $\mathrm{NMSC}$.

\subsection{Location of BCC}

The tumor is almost exclusively found on hair-bearing skin, ${ }^{85}$ especially of the face. Except in the NBCCS, they rarely occur on the palms or soles. Their occurrence on the mucous membrane is doubted. When broken down by location, $85 \%$ of all $\mathrm{BCC}$ appear in the head and neck region, followed by the trunk. Between $25 \%$ and $30 \%$ of $\mathrm{BCC}$ occur on the nose alone, the most common site. ${ }^{87}$ With greater age, the proportion of $\mathrm{BCC}$ that occur on the head and neck region increases and there is a corresponding. reduction in truncal $\mathrm{BCC}{ }^{88}$

Men and women differ in the distribution of BCC by body site. Most BCC are found on the head and neck region in both sexes; however, in women, a higher percentage of $\mathrm{BCC}$ occur on the lower limb compared with men, while the opposite is true for the trunk. Sex-related variations in distribution may reflect differences in clothing and sun exposure. ${ }^{89}$

A majority of the superficial BCC are found on the trunk and upper and lower limbs. This finding contrasts with all the other subtypes of $\mathrm{BCC}$, which are predominantly located on the head and neck region. The difference between superficial BCC and other BCC may indicate that they vary in their causal relationship to sunlight. The development of superficial BCC may be more strongly related to intermittent sunlight exposure. Chronic sun exposure may be an etiologic factor in nodular BCC. ${ }^{90}$ Although the majority of $\mathrm{BCC}$ occur on sun exposed areas, some BCC occur in less exposed areas. Therefore causative factors other than UV-radiation have to be considered." 


\subsection{Histology and clinical features}

Because $\mathrm{BCC}$ is common, histopathology has been considered "classic". Classic features include individual basaloid cells that are uniform and have a bland or nonanaplastic appearance, peripheral palisading of basophilic tumor islands, and retraction of the surrounding stroma from the tumor islands. There may be some differentiation toward appendageal structures, but this does not appear to affect the rate of growth. Although rich in mitotic figures, $\mathrm{BCC}$ is slow to grow. Statistical data predict a rapid doubling in the size of $\mathrm{BCC}$, but clinical observation reveals a slow growth rate. This discrepancy may be explained by the fact that most BCC go through phases of growth and phases of regression. Regression may occur centrally or peripherally.

The histologic subtyping of $\mathrm{BCC}$ has aided in the ability to predict the recurrent or difficult-to-manage tumor. Although $\mathrm{BCC}$ is the most common tumor, for routine histopathology a tumor marker is still lacking.

$\mathrm{BCC}$ may show many different histologic patterns, underscoring the pluripotentiality of the cells. Mixed forms also occur. Wade and Ackerman $^{92}$ catalogue 26 variations in BCC histology:

Solid/nodular - superficial - pigmented - keloidal -cornifying - $\mathrm{BCC}$ with spindled nuclei - bowenoid - adenocystic - morpheic-type - BCC with necrosis - basosquamous carcinoma/ metatypical - calcifying - ossifying - $\mathrm{BCC}$ with follicular differentiation $\mathrm{BCC}$ with deposits of amyloid - $\mathrm{BCC}$ with fibroepitheliomatous features (premalignant fibroepithelioma of Pinkus) - $\mathrm{BCC}$ arising from a hair follicle - BCC with differentiation toward cells like those of sebaceous glands - adamantinoid BCC-adenoid BCC $\mathrm{BCC}$ with eccrine differentiation - cylindromatous $\mathrm{BCC}$ - syringomatous $\mathrm{BCC}$-trichofolliculomatous $\mathrm{BCC}$ - mucinous $\mathrm{BCC}$ - trichoepitheliomatous $\mathrm{BCC}$.

Most BCC can be grouped as non-aggressive and aggressive (Table 2).

Table 2. Histologic subtypes of BCC

\begin{tabular}{l} 
Non-aggressive \\
Nodular $(45 \%-60 \%)$ \\
Superficial $(15 \%-35 \%)$ \\
Aggressive $(4 \%-17 \%)$ \\
Morpheic (sclerosing) \\
Micronodular \\
Infiltrative \\
Basosquamous/netatypical \\
(Adlenocystic) \\
\hline
\end{tabular}

Studies that rely on data derived from the histological diagnosis are likely to underestimate significantly the true prevalence of each subtype of BCC. Superficial BCC are more likely to be treated by in situ destructive measures without histopathological confirmation of the diagnosis. Data collected from pathology reports may therefore 
underestimate the relative prevalence of superficial BCC. Most primary (untreated) $\mathrm{BCC}$ are of the nodular or superficial histologic subtype, tend to grow slowly and are detected prior to attending $1.0 \mathrm{~cm}$ in greatest diameter. The morphea-like $\mathrm{BCC}$ may be more difficult to detect clinically, and frequently it is larger than $1.0 \mathrm{~cm}$ at the time of presentation. The subgroup of aggressive and invasive $\mathrm{BCC}$. morpheic/sclerosing, basosquamous or infiltrating $\mathrm{BCC}$, have high rates of recurrence (12-30\% vs $1-6 \%$ for nodular forms). ${ }^{11}$

Clinical appearance: Six clinical types of BCC occur:

1) The nodular $B C C$ is a waxy, semitranslucent papule or nodule. The border is often pearly and rolled, and telangiectasias course over the surface of the lesion. Eventually, central ulcerations develop. Histopathology: "classic" features of $\mathrm{BCC}$, including large tumor nests with a smooth palisaded border and stromal retraction. It is important to examine the deep margin before finally assigning a subtype to the tumor. In some instances, there may be classic nodular tumor in the superficial portion of the tumor, but in deeper areas the tumor may start sending out "spikes" of the infiltrate tumor. See figure $\mathrm{la}$ and $\mathrm{lb}$.

2) Morpheic $B C C$ has also been called sclerosing $\mathrm{BCC}$, although morpheic is now the more commonly accepted term. It is a solitary, flat or slightly depressed, indurated, yellowish plaque. The surface is smooth and shiny. The border is often ill defined, making therapy more difficult. As these lesions enlarge they may become depressed and firm, often resembling a scar.

Histopathology: extensive sclerosis of the collagen with thick, scarlike collagen fibers and bundels. The tumor cells seem to be forcing their way through this connective tissue in thin strands. The cells are often paler than those of other subtypes, and there is seldom stromal retraction. See figure $2 a$ and $2 b$.

Infiltrating $\mathrm{BCC}$ has nests of variable size (although these are usually small) with what has been called irregular, spiky, jagged, pushing, or even morpheic borders. There is frequently little palisading and there may not be any stromal retraction.

3) The sisperficial $B C C$ is a slightly raised, pink or red, scaly, focally crusted plaque.

The morpheaform $\mathrm{BCC}$ appears as an ivory plaqe with overlying telangiectasias.

Histopathology: budding from the epidermis. This subtype requires all tumor nests to be in continuity with the epidermis. When nests extend more deeply and are freestanding, the tumor should be classified on the morphology of the deeper nests. Figure $3 \mathrm{a}$.

4) Pigment in $B C C$, although not truely a histologic subtype, does seem to have treament implications. ${ }^{93}$ Pigment is less frequently seen in infiltrative tumors, making it less commonly associated with aggressive tumors. Some consider the brown pigment, the only difference between pigmented $\mathrm{BCC}$ and nodular $\mathrm{BCC}$. When $\mathrm{BCC}$ are heavily pigmented, differentiation from malignant melanoma or deeply pigmented seborrheic keratosis can be difficult. Figure $3 b$.

5) Premalignant fibroepithelioma of Pinkus consists of usually only one but occasionally of several raised, moderately firm, slightly pedunculated nodules, covered by smooth, slightly reddened skin. This lesion is now regarded as a variant of $B C C$.

6) Basosquamous $B C C$ is a variant showing features of true $\mathrm{BCC}$ with squamous 
maturation of either tumor nests or abutting aggregates of $\mathrm{SCC}$. The presence of a transition zone does not support the concept that all basosquamous BCC are collision tumors, but rather a differentiation of one tumor into another ${ }^{9.4}$. Whether basosquamous cell carcinoma is a variant of $\mathrm{BCC}$ or $\mathrm{SCC}$ has not been determined, nor has its prognosis been evaluated prospectively. This is a tumor that needs further study, but must be treated as an aggressive subtype of $\mathrm{BCC}$. See figure $3 \mathrm{c}$.

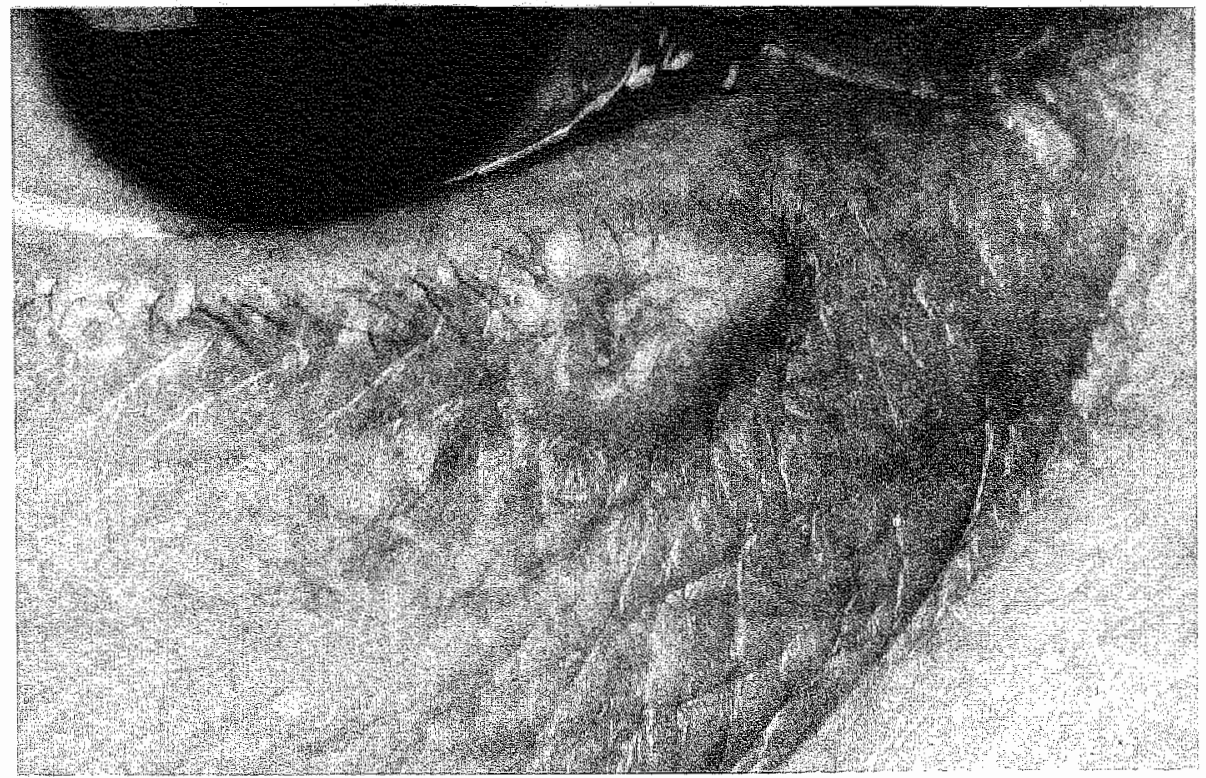

Fig la, nodular BCC

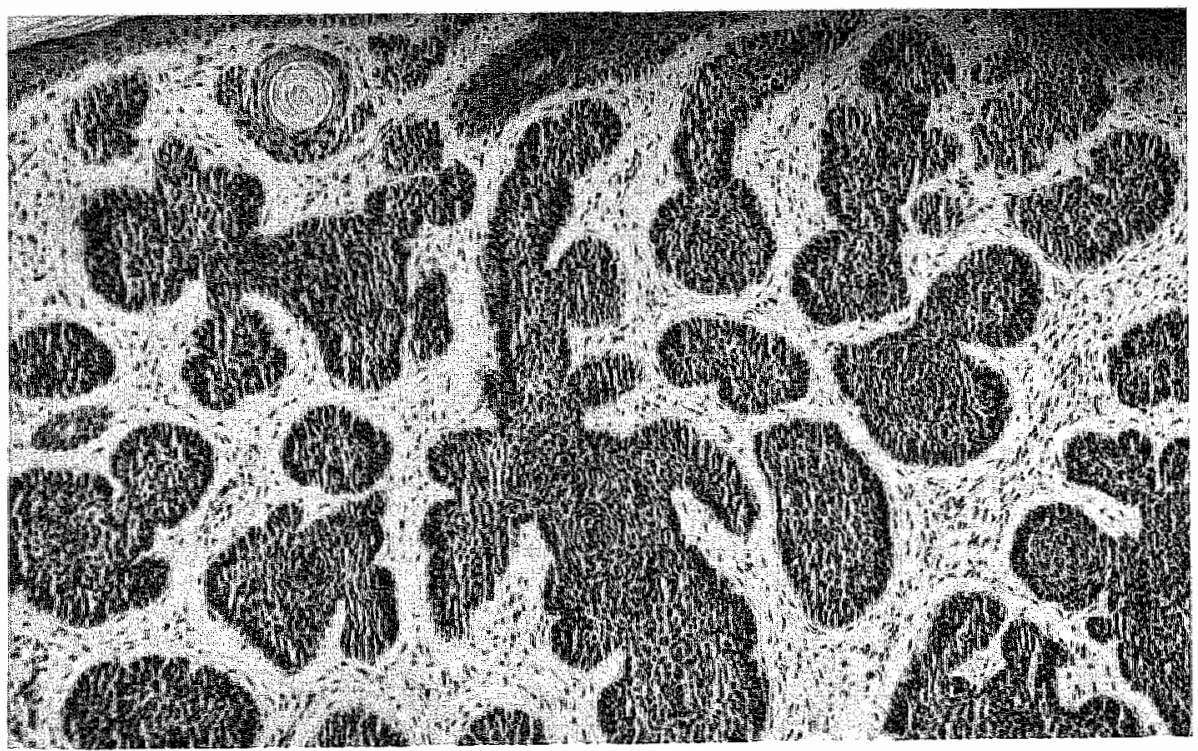

Fig Ib, histopathology of nodular BCC 


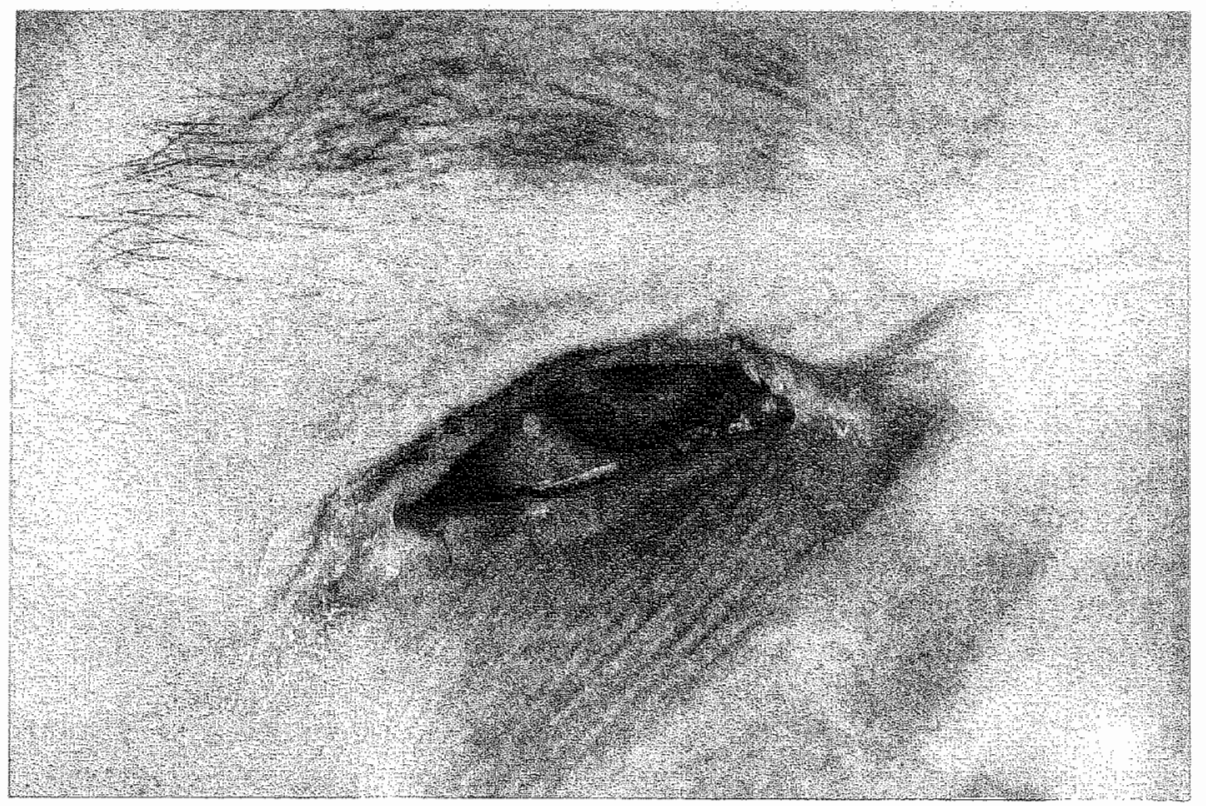

Fig 2a, morpheic and infiltrating BCC (leading to loss of the eye)

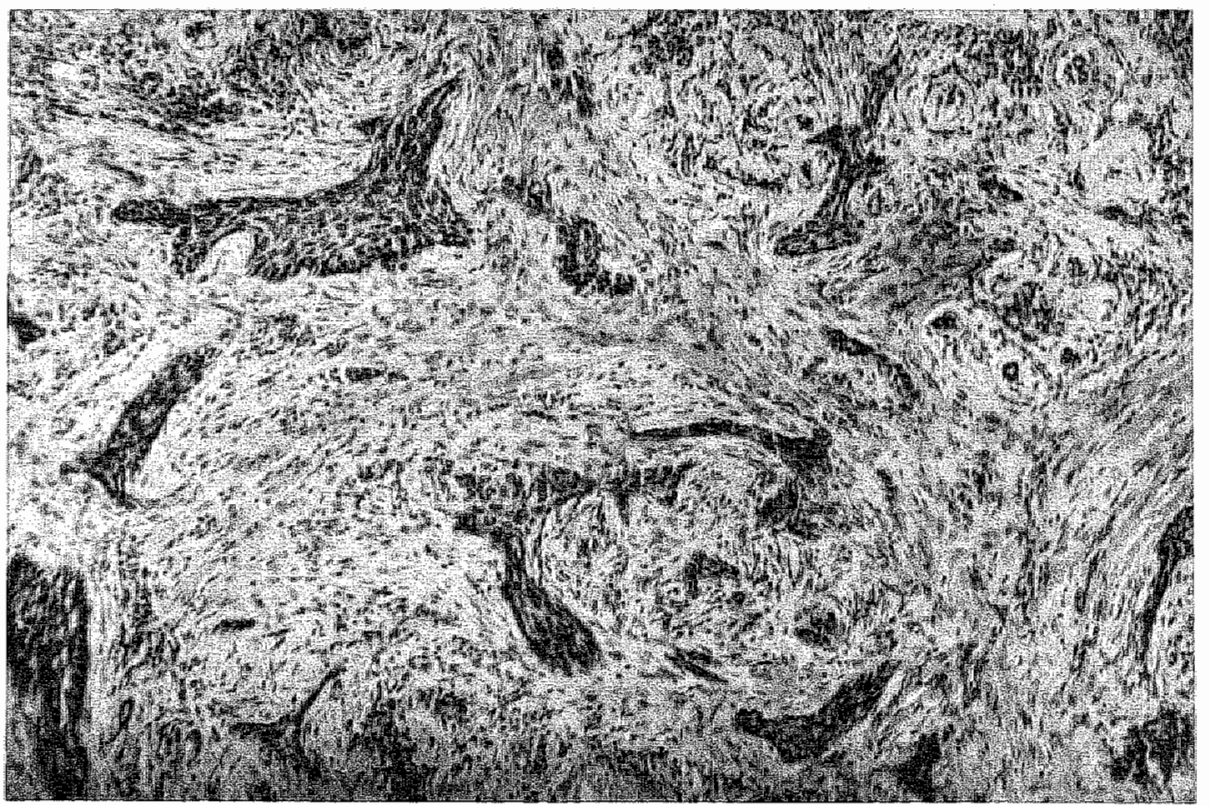

Fig $2 b$, histopathology of morpheic BCC 


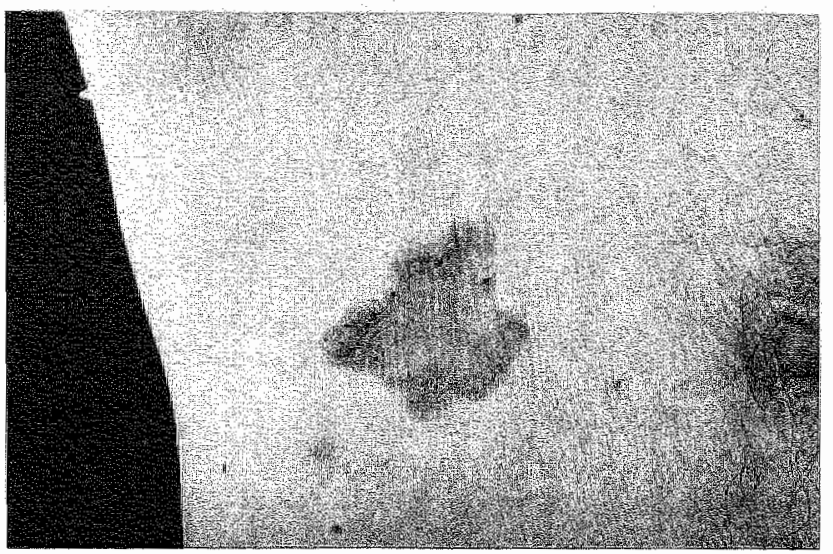

Fig $3 a$, superficial BCC

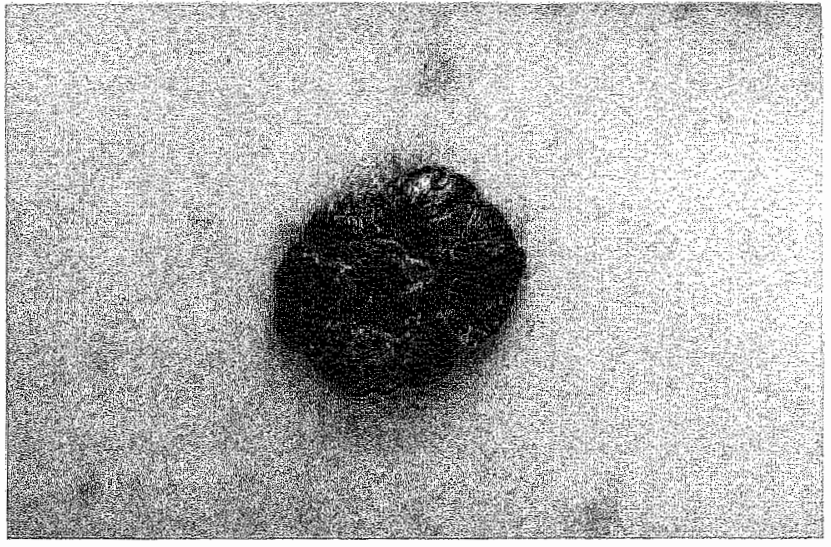

Fig 3t, pigmented $\mathrm{BCC}$

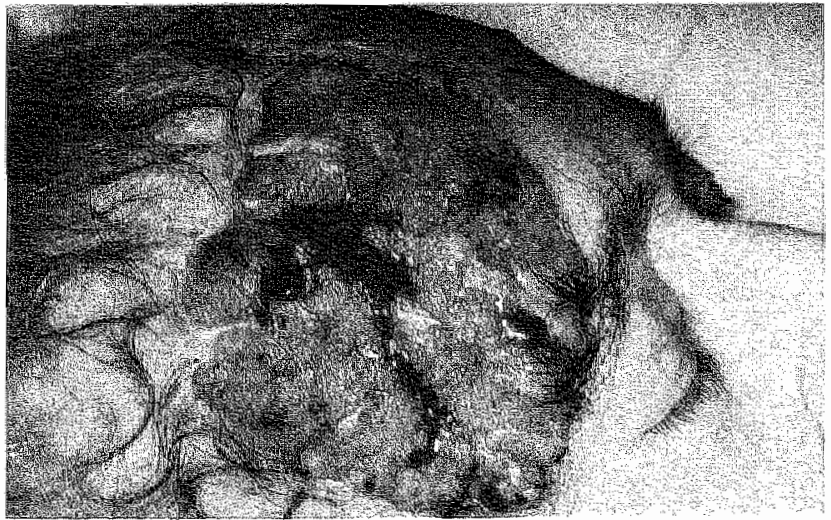

Fig 3c basosquamous $\mathrm{BCC}$ 


\subsection{Treatment modalities for $\mathrm{BCC}$}

Ideally, all BCC should be biopsied before definitive therapy is carried out. This allows for histologic subtyping, determination of the extent of the $\mathrm{BCC}$ and the selection of the most appropriate treatment modality.

In each case characteristics such as tumor history (previous skin cancer, first primary tumor, recurrent tumor, multiple primary tumors at separate sites) histologic subtype, size, anatomic location, patient age, previous therapy, and other medical problems have to be taken into account when determining the optimal treatment plan. ${ }^{95,96}$

Randomised trials that objectively compare the risks and benefits of alternative treatments are lacking. In a first prospective randomised study, ${ }^{97}$ comparing surgery (with frozen sections) and radiotherapy, for previously untreated $\mathrm{BCC}$, surgery was shown to be superior to radiotherapy in treatment efficacy and cosmetic result. For untreated $\mathrm{BCC}$ of the face of less than $4 \mathrm{~cm}$, surgery is recommended as first-line treatment.

Tabel 3. Treatment modalities for BCC

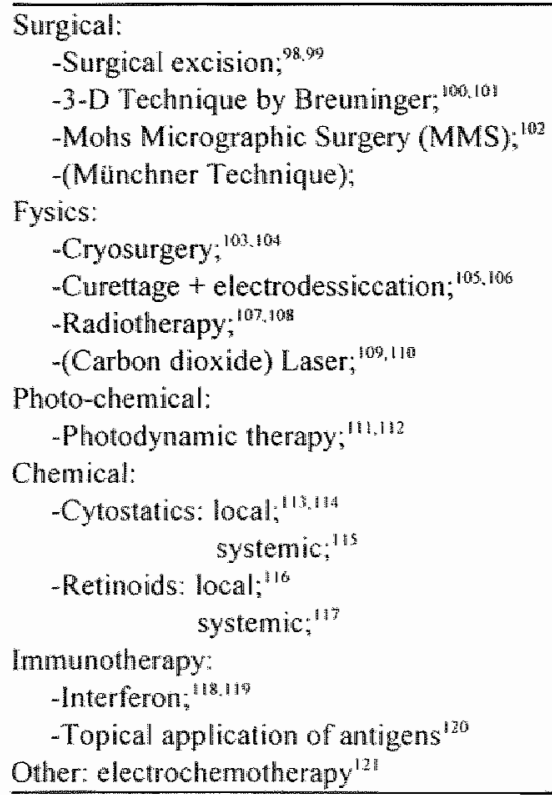

\subsection{Recurrence}

$\mathrm{BCC}$ may be behaviorally subdivided into three types: primary (untreated), recurrent (previously treated), and metastatic. ${ }^{122}$ Analysis of recurrent $\mathrm{BCC}$ lesions is difficult because initial treatment, as well as localization, histology, and size appears to play a role in their development. 
First of all, incompletely excised $\mathrm{BCC}$ are those most likely to recur. Some studies analysing excision of $\mathrm{BCC}$ have shown a lower recurrence rate of tumors than would be expected from the number of inadequate excisions on hisiological appearance. Another, more recent study, however, found a 100\% recurrence rate in incompletely excised $\mathrm{BCC}{ }^{123}$ The mechanism of apoptosis may account for the phenomenon of spontaneous regression. ${ }^{124}$

Tumors extending to the margin of excison which are infiltrative in pattern and located on the head and neck may be particularly likely to recur, and immediate re-excision should be considered in these patients. ${ }^{125}$ The form of therapy chosen plays an important role in defining the risk of recurrence. Five-year recurrence rates for primary $\mathrm{BCC}$ are as follows: MMS, 1\%; surgical excision, $10.1 \%$; curettage and electrodessiccation, $7.7 \%$; radiotherapy, $8.7 \%$; and cryosurgery, $7.5 \%{ }^{126}$ However, the 5 -year recurrence rate for treatment of recurrent (previously treated) $\mathrm{BCC}$ by $\mathrm{MMS}$ is $5.6 \%$; surgical excision, $17.4 \%$; curettage and electrodesiccation, $40 \%$ radiotherapy, $9.8 \%$; and cryosurgery, $13 \%{ }^{127}$

$\mathrm{BCC}$ most frequently recur when located on the $\mathbb{H}$-zone of the face: the inner canthus, the nose (nostril base) or ear (pre-and post-auricular areas). ${ }^{128,129}$ These are the areas where repairs are more difficult, and there is a tendency to consider the method of repair when selecting the margin of excision around the tumor. It has been suggested that (for cosmetic reasons) inadequate excisions are more common in the region of the eyelids and in young women. ${ }^{130}$ A possible explanation is the presence of embryologic tissue planes in regions of the nose, which allows BCC tumors to spread vertically more easily than horizontally, producing an "iceberg effect". "i31 Another suggestion is that the unique microanatomy of the nose, with numerous sebaceous follicles embedded in a dense fibrous stroma, provides pockets in which tumor islands can "hide". 132

Risk of BCC recurrence also varies with its histologic subtype. Tumors of the morpheaform, infiltrative, metatypical (basosquamous), and micronodular variety have the highest recurrence rate. . $^{133.134}$

Recurrent BCC may be very aggressive and may have histologic features not seen in the original neoplasm. In a recent study, ${ }^{135}$ there was a significant association between histologic pattern and adequacy of excision. BCC with nodular and superficial patterns (non-aggressive) had fewer positive margins compared with $\mathrm{BCC}$ with micronodular, infiltrative, morpheic, and mixed patterns (aggressive). These tumor subtypes have larger, undetectable subclinical extensions that make them more difficult to excise completely with a technique that does not examine all margins (e.g. MMS). Thus, histologic pattern correlates with the adequacy of excision, which in turn is a predictor of $B C C$ recurrence. Recurrent $B C C$ of the nodular type, when first excised, may show features of the morphea type at the deep invasive margin. ${ }^{136}$ 


\subsection{Risk of subsequent tumor}

Once an individual develops a NMSC, there is a $36-52 \%$ chance that a new skin cancer will appear within 5 years; ${ }^{13 \%}$ : 38 the greatest risk occurs during the first 12 months after the index NMSC has been removed. ${ }^{139}$ Factors determining time between first primary tumor presentation and the next primary lesion are unclear. However, it has been shown that, patients with a truncal tumor at first presentation, especially males and those presenting with more than one lesion have a significantly decreased time to presentation of further tumors. Therefore these patients should receive more meticulous follow-up. ${ }^{140}$ Recently risk factors for multiple BCC ( $\mathrm{BBCC}$ ) were identified: skin tumor among relatives and sunburn after the age of $60 .^{\text {In }}$ In another study it was shown that truncal $\mathrm{BCC}$ was also associated with $\mathrm{mBCC}$. ${ }^{\text {An }}$

In addition to having an increased risk for new skin cancer, patients with BCC might have an increased risk for noncutaneous cancer at warious sites. Increased risks for non-Hodgkin lymphoma, leukemia, cancer of the lip, testis, breast, salivary glands, mouth, lungs, and kidney, has been described, particularly in patients where BCC were diagnosed when they were at a young age. 143,144

\subsection{Metastasis}

Although rarely metastatic, 1 ,5 the tumor is capable of significant local destruction and disfigurement. Cecile Beadles reported the first pathologic proof of rodent ulcer in

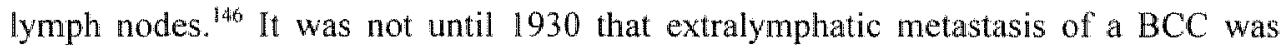
documented. $^{1.77}$ Metastatic $\mathrm{BCC}$ are very rare and are often detected 10 years or more after the treatment of the primary tumor. When BCC metastisize, the prognosis is infaust. $^{148}$ Spread most commonly occurs via the lymphatics to regional nodes and via the bloodstream to the long bones and lungs. Other sites, including the skin may be affected. The incidence varies from $0.0028 \%$ in an Australian community office setting ${ }^{149}$ to $0.1 \%$ in a New York City tertiary hospital. ${ }^{150}$ Three criteria define metastatic NMSC: the primary tumor is not on a mucous membrane; the metastasis is not at the site of the primary tumor, and the histologic profiles of the primary and metastatic tumors are identical.

Metastatic BCC are rare, but when they occur they are often found on the head and neck and/or associated with so called giant BCC. ${ }^{151}$ Giant BCC is a clinical expression for a large-sized BCC. The size limit established by the American Joint Committee on Cancer is $5 \mathrm{~cm}$ or greater in diameter. ${ }^{152}$ Blewitt concluded that large size of the prima ry lesion is the most outstanding feature of metastatic BCC and that metastatic potential is related to depth of invasion. ${ }^{153}$ The primary tumor may show vascular invasion and perineural involvement. Any histologic subtype of BCC may give rise to metastases. Basoquamous histology correlates in some studies, ${ }^{154.155}$ although not in others, with an increased risk of metastasis. 
While some authors consider squamous metaplasia in BCC a sign of differentiation without any impact on clinical behavior, others correlate the changes with a more aggressive phenotype and even a tendency to metastasize, and thus a greater degree of caution in the treatment of these $\mathrm{BCC}$ may be appropriate (Lever WF). The difference between the metastatic potential between $\mathrm{BCC}$ and $\mathrm{SCC}$ may be due to a different expression of the $\mathrm{Nm} 23$ gene, (a putative metastasis suppressor gene), which is expressed in $\mathrm{BCC}$ and almost not expressed in SCC. ${ }^{156}$

\subsection{Follow-up}

Lifelong follow-up is suggested for any patient treated for BCC. Regular follow-up should include the search for recurrence and for any new tumors, (NMSC, melanoma), ${ }^{157,158}$ to which these patients are more susceptible. ${ }^{159,160,161}$

For BCC: follow-up every 3 month for the first year; every 6 month for the second year and thereafter yearly examination of "total-body-skin". Although continued follow-up of patients with NMSC facilitates the early detection of new tumors and recurrences, the use of long-term surveillance is not common. It is time-consuming and costly. Among the people for whom annual examination is most appropriate are those who had a skin cancer within the past five years, those with severely sun-damaged skin or multiple actinic keratoses, persons with a genetic predisposition, immunocompromised patients, and persons with long-term exposure to chemical carcinogens or ionizing radiation.

While not cancerous of themselves, actinic keratoses (AK or solar keratoses) are precancers and are recognized as a risk factor for $\mathrm{BCC}$ and $\mathrm{SCC} .{ }^{162}$ Thus, they can serve as an early "skin cancer risk marker", as well as a biomarker in chemopreventive studies. ${ }^{163,164} \mathrm{AK}$ are common dysplastic epidermal lesions which occur in pale-skinned individuals who are chronically exposed to intense sunlight. Reported AK prevalence rates range from $11 \%$ to $25 \%$ in various northern hemisphere populations. Among Australian adults the range is from $40 \%$ to $60 \%$. ${ }^{165}$ The regular application of a highprotection sunscreen by subjects over 40 years of age was reported to reduce the mean number of AK. ${ }^{166.167}$

NMSC are associated with substantial morbidity (including loss of function and disfigurement) and their treatment is costly. For both melanoma and NMSC, prognosis improves when lesions are detected early. Early detection can reduce morbidity and cost. Given the high incidence of skin cancer, all primary care physicians should be screening patients, performing biopsies, and diagnosing and treating skin cancers or referring patiens with suspicious lesions. ${ }^{168}$ Screening is simple and can be easily incorporated into the routine physical examination. ${ }^{169}$ Physicians must be trained to recognize the clinical appearance of $\mathrm{BCC}$ and other skin cancers and their precursor lesions in order to prevent the development or progression of these cutaneous malignancies. Likewise, patients should be taught to routinely examine their skin and seek medical evaluation for changes in skin growths or the appearance of new lesions. 
Recommendations for skin cancer screening vary among major health policy organizaw tions. The American Cancer Society recommends annual skin examinations for adults 40 years of age and older. ${ }^{17}$ Although screening of the skin is an important means by which to detect skin cancers, the cost-effectiveness of examining the general population is questionable. ${ }^{171}$ Perhaps a more realistic goal would be to recognize and screen only those at high risk to acquire skin cancer. High risk patients (immune compromised patients, like renal transplant patients; skin cancer patients; etc) should also be educated about their condition and followed closely over the entire course of their lives by knowledgeable health care professionals. ${ }^{172}$

\subsection{BCC Prevention}

Prevention should focus on the one known aetiological factor, sunlight ${ }^{173}$ Especially young children and teenagers should not be exposed to sunlight needlessly and should never be exposed to tanning-devices. Avoidance of sun, especially in the middle of the day, when UV flux is highest, is the best form of protection. Wearing protective clothing (sun protection afforded by textiles) ${ }^{174}$ such as long-sleeved shirts and broadbrimmed hats, and the use of a high-protection sunscreen ${ }^{175}$ are more practical measures. In Australia the "Slip, Slap, Slop" campaign (slip into a shirt, slap on a hat, stop on sunscreen) is well known. Sunscreens should be used especially on the face, the body, and scalp. Nowadays hair sprays and styling products that incorporate sunscreens are commercially available. Sunscreens prevent sunburn, photoageing, DNA damage, UV carcinogenesis and prevent UV-induced immune suppression. ${ }^{176}$ Regularly using sunscreens with SPF $>15$ for the first 18 years of life could decrease lifetime risk of NMSC by $78 \%{ }^{177}$ The public health recommendation that sunscreens with a SPF $>15$ should be used, is an important part of a skin cancer-prevention program. Application of SPF 15 sunscreens to mouse skin before each UV irradiation nearly abolished the frequency of p53 mutations. ${ }^{178} \mathrm{UVB}$ radiation can be reduced by over $93 \%$ if a sunscreen with a SPF of 15 or higher is applied, by $60 \%$ if the sun is avoided from 10 a.m. to 3 p.m., by $70 \%$ (to the head and neck only) if a 4-inchwide brim hat is worn, and by almost $100 \%$ (to the trunk and limbs only) if tightly woven clothing is worn.

Sunlight exposure must be reduced, both in children, teenagers and skin cancer patients. It was demonstrated that a second skin cancer is significantly more likely to occur in patients who continue to receive excessive amounts of sun exposure during the 18-36 months following removal of the first. ${ }^{17 \%}$ This is in marked contrast to the incidence of second cancers in patients with low amounts of sun exposure. Thus, continued sun protection after the removal of a skin cancer is valuable. We often hear" the excuse that there is little point in protecting older people from further sun-induced injury. However, many 65 -year-olds live another 15 , or even 35 years. That is a long time to continue to be (over)exposed to UVR.

A hypothetical issue has been raised concerning sunscreen use in older people, as their skin is less efficient in producing witamin D. It was shown that small amounts of UVB 
are sufficient for vitamin D production and the use of potent broad-spectrum sunscreens does not result in a vitamin D deficiency. ${ }^{180}$

Retinoids seem promising for the future. Currently retinoids are used systemically and topically for chemoprevention of $\mathrm{BCC}$ and other skin cancer. ${ }^{181}$ The effects of retinoids on the development of BCC seem however, less promising than the effects on $\mathrm{SCC}{ }^{182}$ Rejuvenation (chemical peeling, dermabrasion, and carbon-dioxide-laserresurfacing) is currently used in anti-aging procedures, but could prove therapeutic potential in skin cancer prevention as well. ${ }^{183}$ Since chronic sun-induced injury affects primarily the epidermis, removal of this top layer causes new, healthier tissue to take its place. ${ }^{184}$

Finally, some tips for skin cancer prevention:

- Use a sunscreen with both UVA and UVB protection with a high sun protection factor (SPF of at least 15), every day. (When outdoors this should be done every 2 hours, and every hour when exposed to water/sweat). Ears and lower lip are often forgotten!

- Wear protective clothing, including a hat with a wide brim (can keep $70 \%$ of the UVR from reaching the head and neck), long-sleeved shirts, long pants, and sunglasses that block UVA and UVB.

- Minimize your exposure to the sun, especially between 10 AM and 4 PM, when $60 \%$ of the day's sunburning UVR reaches the earth.

- Be especially careful on water, sand, snow or high elevation.

- Avoid artificial tanning devices.

- Take special precautions with children. 


\section{References}

1. Kibarian MA, Hruza GI. Nonmelanoma skin cancer. Postgraduate Med 1995:98:39-58.

2. Lebert $H$. Traite practique des maladies canceureuses. Paris: Balliere, $1851: 263 \mathrm{ff}$.

3. Hutchinson J. A clinical report on rodent ulcer. Med Times Gazette. 1860;2:156-8, 182-6, 237-8, $304-7$.

4. Jacob A. Observations respecting an ulcer of peculiar character, which attacks the eyellids and other parts of the face. Dublin Hosp Rep 1824,4:232-9.

5. Krompecher E. Der Basalzellenkrebs (monograph). Jena: G.Fischer, 1903.

6. Shimizu $N$, Ito M, Tazawa $T$, Katsumi $K$, Sato $Y$. Anti-keratin monoclonal antibody against basal cell epithelioma keratin: BKN-1. J Dermatol (Tokyo) 1987:14:359-63.

7. Asada M, Schaart FM, Almeida HL, et al. Solid Basal Cell Epithelioma (BSE) possibly originates from the outer root sheath (ORS) of the hair follicle. Acta Derm Venereol (Stockh) $1993,73: 286-92$.

8. Brody I. Contributions to the histogenesis of basal cell carcinoma. J Ultrastruct Res 1970;33:6079 .

9. Kumakiri $\mathrm{M}$, Hashimoto $\mathrm{K}$. Ultrastructural resemblance of basal cell epithelioma to primary epithelial germ. J Cutan Pathol 1978:5:53-67.

10. Marks R. An overview of skin cancers: incidence and causation. Cancer $1995 ; 75 ; 607-12$.

11. Preston DS, Stern RS. Nonmelanoma cancers of the skin. N Engl J Med 1992;327:1649-62.

12. McCarthy WH, Shaw HM. Skin cancer in Australia. Med J Aust 1989;150:469-70.

13. Marks R, Jolley D, Lectsas S, Foley P. The role of childhood exposure to sunlight in the development of solar keratoses and non-melanocytic skin cancer. Med J Aust 1990;152:62-6.

14. Green A, Beardmore $G$, Hart $V$, et al. Skin cancer in a Queensland population. J Am Acad Dermatol 1988:19:1045-52.

15. Schreiber MM, Shapiro SI, Berry CZ, Dahlen RF, Friedman RP. The incidence of skin cancer in Southern Arizona (Tucson). Arch Dermatol 1971;104:124-7.

16. Stenbeck KD, Balanda KP, Williams $M J$, et al. Patterns of treated non-melanoma skin cancer in Queensland - the region with the highest incidence rates in the world. Med $\Downarrow$ Aust 1990;153:5 115.

17. Rigel DS, Friedman RJ, Kopf AW. Lifetime risk for development of skin cancer in the US populations: current estimate is now I in 5. (Editorial) J Am Acad Dermatol 1996;35(6):1012-3.

18. Parker SL. Tong T, Bolden S. Cancer Statistics, 1996 CA Cancer J Clin 1996:46(1):5-27.

19. Silverberg E, Lubera JA. Cancer statistics, 1988. CA 1988:38:14-5.

20. Waterhouse J, Muir C, Correa P. Cancer in Five Continents. Vol 3. Lyon, France: International Agency for Research on Cancer, World Health Organization, 1976.

21. Thissen MR, Neurnann H.A, Berretty PJ, Ideler AH. De behandeling van patiènten met basallecelcarcinomen door dermatologen in Nederland. NTVG 1998;142:1563-7.

22. Neering H, Cramer MJ. Huidkanker in Nederland. Ned Tijdschr Geneeskd 1988;132:1330-3.

23. Coebergh JWW. Incidence and prognosis of cancer in the Netherlands: Studlies based on cancer registries. Thesis University Rotterdam 1991 , ISBN 90-9004\43-5.

24. Coebergh JWW, Neumann HAM, Vrints LW, et al. Trends in the incidence of non-melanoma skin cancer in the SE Netherlands 1975-1988 a registry-based study. Br J Dermatol 1991;125:353-9.

25. Gallagher RP, Ma B, McLean DI, ef al. Trendls in basal cell carcinoma, squamous carcinoma, and melanoma of the skin from 1973 through 1987. J Am Acad Dermatol 1990;23:413-21.

26. Slaper H, Velders GIM, Daniel JS, et al. Estimates of ozone depletion and skin cancer incidence to examine the Vienna Convention achievements. Nature $1996 ; 384256-8$. 
27. Moseley H, Mackie RM. Ultraviolet B radiation was increased at ground level in Scolland during a period of ozone depletion. Br \& Dermatol 1997:137:101-2.

28. Herriksen T, Dahlback A, Larsen $\mathrm{SH}$, Moan 1 . Utraviolet radiation and skin cancer: effect of an oxone layer depletion. Photochem Photobiol 1990;51:579-82.

29. Urbach F. Ultraviolet tadiation and skin cancer of humans. J Photochem Photobiol B 1997:40:37.

30. Gloster HM, Brodland DG. The epidemiology of skin cancer. Dermatol Surg 1996:22:217-26.

31. Weinstock MA. Nonmelanoma skin cancer mortality in the United States, 1969 through 1988. Arch Dermatol 1993;129:1286-90.

32. Weinstock MA, Bogaars HA, Ashley $M$ et al. Nonmelanoma skin cancer mortality: a population* based situdy. Arch Dermatol 1991;127:1194-7.

33. Dunn JE Jr, Levin EA, Linden $G_{\text {, }}$ et al. Skin cancer as a cause of death. Calif Med $1965 ; 102: 301-63$.

34. Leffell DJ, Headington JT, Wong DS, Swanson NA. Aggressive growth basal cell carcinoma in young adults. Arch Dermatol 1991;127:1663-7.

35. Hogan DJ, To T, Gran L, Wong D, Lane PR. Risk factors for basal cell carcinoma. Int J Dermatol $1989 ; 28: 591-4$.

36. Green A, Battistutta D. Incidence and determinants of skin cancer in a high-risk Australian population. Int J Cancer 1990;:46:356-61

37. Giles $\mathrm{GG}$, Marks $\mathrm{R}$, Foley $\mathrm{P}$. Incidence of non-melanocytic skin cancer treated in Australia. $\mathrm{Br}$ Med J [Clin Res] 1988;296:13-7.

38. Kaldor J, Shugg $\mathrm{D}_{0}$ Young $\mathrm{B}$, et all. Non-melanoma skin cancer: ten years of cancer-registrybased surveillance. Int J Dermatol 1993;53:886-91.

39. Chuang TY, Popescu A, Su WPD, et al. Basal cell carcinoma. I Am Acad Dermatol 1990;22:413-7.

40. Cox SE, Roberts LJ, Bergstresser PR. Prevention of skin cancer in xeroderma pigmentosum: The physician as advocate. J Am Acad Dermatol 1993;29:1045-46.

41. Kraemer KH, Lee MM, Scotto J. DNA repair protects against cutaneous and internal neoplasia: evidence from xeroderma pigmentosum. Carcinogenesis 1984;5:511-4.

42. Bialer MG, Gailani MR, McLaughlin JA, et al. Prenatal diagnosis of Gorlin syndrome. Lancet 1994;344:477.

43. Kopera D, Cerroni L, Fink-Puches $R$, Kerl H. Different treatment modalities for the management of a patient with the nevoid basal cell carcinoma syndrome. J Am Acad Dermatol 1996;34:937. 9.

44. Kromberg JG, Castle D, Zwane EM, Jenkins T. Albinism and skin cancer in Southern Africa. Clin-Genet 1989;36:43-52.

45. Herges A, Stieler W, Stadler R. Das Bazex-Dupre-Christol-syndrom. Hautard 1993;44:385-91.

46. Anderson TE, Best PV. Linear basal cell nevus. Br J Dermatol 1962;74:20.

47. Ruiter M.On malignant degeneration of skin lesions on epidermodysplasia verruciformis. Dermatol Venereol 1986:49:309:14.

48. Camisa C, Bikowski JB, McDonald SG. Cowden's disease, association with squamous cell carcinoma of the tongue and perianal basal cell carcinoma. Arch Dermatol 1984;120:677-8.

49. Silverstone H, Searle JHA. The epidemiology of skin cancer in Queensland: the influence of phenotype and environment. Br J Cancer 1970;24:235-52.

50. Granstein RD, Sober AJ. Current concepts in ultraviolet carcinogenesis. Proc Soc Exp Biol Med 1982; ; 170:115-25.

51. Forbes PD. Photocarcinogenesis: an overview.J Invest Dermatol 1981;77:139-43. 
52. Davis MM, Hanke CW, Zollinger TW et al. Skin cancer in patients with chronic radiation dermatitis. J Am Acad Dematol 1989;20:608-16.

53. Karagas MR, McDonald JA, Greenberger ER, et al. Risk of basal cell carcinoma and squamous cell skin cancers after ionizing radiation therapy. I Natl Cancer Inst 1996:88:1848-53.

54. Shannon RL, Strayer DS. Arsenic-induced skin foxicity. Human Toxicol 1989;113:99-104.

55. Lindelof B, Sigurgeirsson B. PUVA and cancer: a large scale epidemiological study. Lancet 1991;338:91-3.

56. Kune GA, Bannerman S, Field B, et al. Diet, alcohol, smoking, serum beta-carotene, and vitamin $A$ in male nonmelanocytic skin cancer patients and controls. Nutr Cancer 1992;18:237 44.

57. Lear JT, Tan BB, Smith $A G$, et al. Risk factors for basal cell carcinoma in the UK: case-control study in patients. J R Soc Med 1997;90:371-4.

58. Pfister $\mathrm{H}$, Ter Schegget J. Role of HPV in cutaneous premalignant and malignant tumors. Clin Dermatol 1997:15:335-47.

59. Mckenna KE, Somerville JE, Walsh MY et al. Basal cell carcinoma occurring in association with dermatofibroma. Dermatology 1993; 187:54-7.

60. Mehregan AH, Pinkus H. Life history of organoid nevi. Arch Dermatol 1965;91:574-88.

61. Noodleman FR, Pollack SV. Trauma as a possible etiologic factor in basal cell carcinoma. J Dermatol Surg Oncol 1986;12:841-6

62. Koga Y, Sawada Y. Basall cell carcinoma developing on a burn scar. Burns 1997;23:75-7.

63. Marghoob A, Kopf A. Risk of amother basal cell carcinoma developing after treatment of a basal cell carcinoma. J An Acad Dermatol 1993;28:22-8.

64. Gupta AK, Cardella CJ, Haberman HF. Cutaneous malignant neoplasms in patients with renal transplants. Arch Dermatol 1986;122:1288-93.

65. Gailani MR, Leffell DJ, Ziegler $A$, et all. Relationship between sunlight exposure and a key genetic alteration in basal cell carcinoma. J Natl Cancer Inst 1996;88:349-54.

66. Stone JL, Reizer $\mathrm{G}$, Scotto J. Incidence of nonmelanoma skin cancer in Katsai during 1983. Hawaii Med 1986;45:281-6.

67. McKnight CK, Magnusson B. Tumors in Iceland. I. Malignant tumors of the skin: a histologic classification. Acta Pathol Microbiol Scand 1979;87:37-44.

68. Fears TR, Scotto J, Schneiderman MA. Mathematical models of age and ultraviolet effects on the incidence of skin cancer among whites in the United States. Am J Epidemiol 1977;105:420. 1.

69. Ramani ML, Bernett RG. High prevalence of skin cancer in World War II servicemen stationed in the pacific theater. J Am Acad Dermatiol 1993;28:733-7.

70. Camplejohn RS. DNA repair in melanoma and non-melanoma skin cancer. Cancer Surv 1996;26:193-206.

71. Basset-Sequin N, Dereure O, Guillot B. Genetic bases of cutaneous tumors. Ann Dermatol Venereol $1995 ; 122: 217-25$.

72. Grossman L. Epidemiology of ultraviolet-DNA repair capacity and human cancer. Environ Health Perspect 1997;105:927-30.

73. Gailani MR, Stalyle-BackdahI M, Leffell DJ. The role of the human homologue of Drosophila patched in sporadic basal cell carcinoma. Nat Genet 1996;14:78-81.

74. Scotto 1 . Kopf AW, Urbaclu f. Non-melanoma skin cancer among Caucasians in four areas of the United States. Cancer 1974;34:1333-8.

75. Roberts DL. Incidence of non-melanoma skin cancer in West Glamorgan, South Wales. Br J Dermatol 1990;122:399-403.

76. Fleming ID, Barnawell JR, Burlison PE, Rankin JS. Skin cancer in black patients. Cancer 1975;35:600-5. 
77. Altman A, Rosen $T$, Tschen JA et al. Basal cell epithelioma in black patients. I Am Acad Dermatol 1987:17:741.5.

78. Mora RG, Burris R. Cancer of the skin in blacks: a review of 128 patients with basal-cell carcinomat. Cancer 1981;47:1436-8.

79. Leong $G K$, Stone $U_{\text {, Farmer }}$ ER, et al. Non-melanoma skin cancer in Japanese residents of Kauai, Hatwail J Am Acad Dermatol 1987,17:233-8.

80. Kaidbey KH, Agin PP, Sayre RM, Kligman AM. Photoprotection by melanin - a comparison of black and Caucasian skin. J Am Acad Dermatol 1979;1:249-60.

81. Bang KM. Halder RM, White JE, et al. Skin cancer in black Americans: a review of 126 cases. J Natl Med Assoc 1987,79:51-8.

82. Dix CR. Occupational trauma and skin cancer. Plast Reconstr Surg 1960;26:546-54.

83. Scotto I, Fraumeni JF Jr. Skin (other than melanoma). In: Schottenfeld D, Fraumeni JF Jr, editors. Cancer epidemiology and prevention. Philadelphia: Saunders, 1982:996-1011.

84. Sommers SC, McManus RG. Multiple arsenical cancers of skin and internal organs. Cancer $1953 ; 6: 347-59$.

85. Lever's histopathology of the skin. 8th ed. Philladelphia: Lippincott: 719-31.

86. Urmacher $\mathrm{C}$, Pearlman $\mathrm{S}$. An uncommon neoplasm of the oral mucosa. Am J Dermatopathol $1983 ; 5: 601-4$.

87. Roenigk RK, Ratz JL, Bailin PL et al. Trends in the presentation and treatment of basal cell carcinoma. J Dermatol Surg Oncol 1986;12:860-5.

88. McCormack. CJ, Kelly JW, Dorevitch AP. Differences in age and body site distribution of the histological subtypes of basal cell carcinoma. Arch Dermatol 1997;133:593-6.

89. Scotto J, Fears FR, Fraumeni JF. Incidence of Nonmelanoma Skin Cancer in the United States. Bethesda, Md: National Cancer Institute; 1983. US Dept of Health and Human Services publication NIH 83-2433.

90. Bastiaens MT, Hoefnagel JJ, de Bruijn JA et al. Differences in age, site distribution, and sex between nodular and superficial basal cell carcinomas indicate different types of tumors. J Invest Dermatol 1998;110:880-4.

91. Matsumara $Y$, Nishigori $C$, Yagi $T$, et al. Characterization of 553 gene mutations in basal cell carcinomas: comparison between sun-exposed and less-exposed skin areas. Int I Cancer 1996;65:778-80.

92. Wade TR, Ackerman AB. The many faces of basal-cell carcinoma. I Dermatol Surg Oncol $1978: 4: 23-8$.

93. Maloney ME, Jones DB, Sexton FM. Pigmented basal cell carcinomas: investigation of 70 cases. J Am Acad Dermatol 1992;27:74-8.

94. Jones $M S_{\text {, Heim }} \mathrm{KF}_{\text {, Maloney }} \mathrm{ME}$. The immunohistochemical characteristics of the basosquar mous cell carcinoma. Dermatol Surg 1997;23:181-4.

95. Lang PG Jir. Variables to consider in the management of non-melanoma skin cancer. $J$ Geriatr Dernatol 1996;4:231-7.

96. MarghoobAA. Basal and squamous cell carcinomas. What every primary care physician should know. Postgr Med 1997:102:139-59.

97. Avril M-F, A uperin A, Margulis A, et al. Basal cell carcinoma of the face: surgery or radiotherapy? Results of a randomised study. Br J Cancer 1997;76: 1 00-6.

98. Blonnquist G, Eriksson E, Lauritzen C. Surgicall results in 477 basal cell carcinomas. Scand J Plast Reconstr S 1982;16:283-4.

99. Goldberg DP. Assessment and surgical treatment of basal cell carcinoma. Clin Plast Surg 1997,24:673-86.

100. Breuninger $H$, Rassner $G$, Schaumburg-Lever $G$, Steitz A. Langzeiterfarungen mit der technik der histologische schnittrandkontrolle (3-D-Histologie). Hautarzt 1989;40:14-8. 
101. Breuninger H. Micrographic surgery of malignant skin tumors: a comparison of the frozen technique with paraffin sectioning. Facial Plast Surg 1997; 13:79-82.

102. Robinson Jk. Mohs Micrographic Surgery. Clin Plast Surg 1993;20:149-56.

103. Bullock JD, Beard C, Sullivan JH. Cryotherapy of basal cell carcinoma in oculoplastic surgery. Am J Opthanimology 1976;82:841*7.

104. Zacarian SA. Cryosurgery of cutaneous carcinomas: An eighteen year study of 3022 patients with 4028 carcinomas. $J$ Am Acad Dermatol 1983;9:947-56.

ID5. Eders BL, Bartlow GA, Haghighi P, Astarita RW, Davidson TM.Effectiveness of curettage and electrodesiccation in the removal of basal cell carcinoma. J Am Acad Dermatol 1983;9:383-8.

106. Adam JE. The technic of curettage surgery. J Am Acad Dermatol 1986;15:697-702.

107. Braun-Falco $\mathrm{O}$. Lukacs $\mathrm{S}$. Dermatologische Rontgentherapie. Springer Verlag, Berlin Heidelberg New York, 1973 pp 64-67,93-4.

108. Fitzpatrick P, Thompson GA, Easterbrook WM, et al. Basal and squamous cell carcinoma of the eyelids and their treatment by radiotherapy. Int J Radiol Oncol Biol Phys 1984; 10:449-54.

109. Landthaler M, Szeimies RM. Hohenleutner U. Laser therapy of skin tumors. Recent Results Cancer Res 1995;139:417-21.

110. Bandieramonte G, Lepera P, Moglia D, et al. Laser microsurgery for superficial T1-T2 basal cell carcinoma of the eyel id margins. Opthalmology 1997;104:1179-84.

111. McCaughan JS Ir, Guy JT, Hicks W, et al. Photodynamic therapy for cutaneous and subcutaneous malignant neoplasms. Arch Surg 1989;124:211-6.

112. Feyh J. Photodynamic treatment for cancers of the head and neck. I Photochem Photobiol $1996 ; 36: 175-7$.

113. Orenberg EK, Miller BH, Greenway HT, et al. The effect of intralesional 5-Fluorouracil therapeutic implant (MPI 5003) for treatment of basal cell carcinoma. I Am Acad Dermatol $1992 ; 27 ; 723-8$.

114. Stange PR, Lange PG. Long-term management of basal cell nevus syndrome with topical tretinoin and 5-Fluorouracil. J Am Acad Dermatol 1992;27:842-5.

115. Guthrie TH Jr, MeElveen LJ, Porubsky ES, et al.Cysplatin and doxorubicin. An effective chemotherapy in the treatment of advanced basal cell and squamous carcinoma of the skin. Cancer 1985;55:1629-32.

116. Brenner $S$, Wolf $\mathbb{R}$, Dascula DI.Topical tretinoin treatment in basal cell carcinoma. J Dermatol Surg Oncol 1993;19:264-6.

117. Hughes BR, Marks R, Pearse AD, Gaskell SA.Clinical response and tissue effect of etretinate treatment of patients with solar keratoses and basal cell carcinoma. J Am Actd Dermatol $1988: 18: 522-9$.

118. Greenway HT, Comell RC, Tanner DJ, et all. Treatment of basal cell careinoma with intralesional interferon. J Am Acad Dermatol 1986:15:437-43.

119. Buechner $S A$. Intralesional interferon alfa $2 b$ in the treatment of basal cell carcinoma. J Am Acad Dermatol 1991;24:731-4.

120. Klein $\mathrm{E}$, Holtermann $\mathrm{OA}$, Helm $\mathrm{F}$ et al. Immunologic approaches to the manangement of primary and secondary tumors involving the skin and soft tissues: review of a ten-year program. Transplant Proc 1975:7:297-315.

121. Glass LF, Jaroszeski M, Gilbert R, et al. Intratesional bleomycin-mediated electrochemotherapy in 20 patients with basal cell carcinoma. J Am Acad Dermatol 1997,37:596-9.

122. Miller SJ. Biology of basal cell carcinoma (I). J Am Acad Dermatol 1991:24:1-13.

123. Friedman HI, Williams $T$, Zamora $S$, al-Assaad ZA. Recurrent basal cell carcinoma in marginpositive tumors. Ann Plast Surg 1997;3:232-5.

124. Taylor GA, Barisoni D. Ten years" experience in the surgical treatment of basal cell carcinoma. Br J Surg 1973;60:522-5. 
125. Rippey J Rippey $\mathbb{E}$. Characteristics of incompletely excised basall cell carcinomas of the skin. Med J Aust 1997;1665:581-3.

126. Rowe DE, Carroll RJ, Day CL Jr. Long-term recurrence rates in previously untreated (primary) cell carcinonta: implications for patient follow-up. J Dermatol Surg Oncol 1989;15:315-28.

127. Rowe DE, Carrol RJ, Day CL Jr. Mohs surgery is the treatment of choice for recurrent (previously treated) batsal cell carcinoma. I Dermatoll Surg Oncol 1989;15:424-31.

128. Roenigk RK, Ratz $\mathrm{JL}$, Bailin $\mathrm{PL}$ et al. Trends in the presentation and treatrment of basal cell carcinoma. J Dermatol Surg Oncol 1986;12:860-5.

129. Kopf AW. Computer analysis of 3531 basal-cell carcinomas of the skin. J Dermatol (Tokyo) $1979 ; 6: 267-81$.

130. Robins $\mathbb{P}_{3}$ Albom MJ. Recurrent basal cell carcinomas in young women. IJ Dermatol Surg $1975 ; 1: 49-51$.

131. Panje WR, Ceilley RI. The influence of embryologic of the mid-face on the spread of epithelial malignancies. Laryngoscope 1979;89:1914-20.

132. Salasche SJ. Curretage and electrodesiccation in the treatment of midfacial basal cell epithelioma. I Am Acad Dermatol 1983;8:496-503.

133. Siegle RJ, MacMillan J, Pollack SV. Infiltrative basal cell carcinoma: a nonsclerosing subtype. J Dematol Surg Oncol 1986;12:830-6.

134. Lang PG Jr, Maize IC. Histologic study of recurrent basal cell carcinoma and treatment implica. tions. J Am Acad Dermatol 1986; 14:186-96.

135. Sexton M, Jones DB, Maloney ME. Histologic pattern analysis of basal cell carcinoma: study of a series of 1039 consecutive neoplasms. J Am Acad Dermatol 1990;23;1118-26.

136. Robinson $\mathrm{JK}$. Expression of keratin proteins in deeply invasive basal and squamous cell carcinoma: An immunohistochemical study. J Dermatol Surg Oncol 1987;13:283-94.

137. Schreiber MM, Moon TE, Fox SH, et al. The risk of developing subsequent nonmelanoma skin cancers. J Am Acad Dermatol 1990;23:1 114-8.

138. Frankel DH, Hanusa BH, Zitelli JA. New primary nonmelanoma skin cancer in patients with a history of squamous cell carcinoma of the skin. Implications and recormmendations for followup. J Am Acad Dermatol 1992;26:720-6.

139. Robinson JK. Risk of developing another basal cell carcinoma: a 5-year prospective study. Cancer 1987;60:118-20.

140. Lear $\mathrm{JT}$, Smith $\mathrm{AG}_{3}$ Heagerty $\mathrm{AH}$, et al. Truncal site and detoxifying enzyme polymorphisms significantly reduce time to presentation of further primary cutaneous basal cell carcinoma. Carcinogenes is 1997; 18:1499-503.

141. Waltberg P. Kaaman T, Lindberg M. Multiple basal cell carcinoma. Acta Derm Venereol (Stockin) 1998;78:127-9.

142. Lear JT, Smith $\mathrm{AG}_{\mathrm{G}}$, Strange RC, et al. Patients with truncal basal cell carcinoma represent a high-risk group. Arch Dermatol 1998;134:373.

143. Frisch $\mathrm{M}, \mathrm{Hjalgrim} \mathrm{H}$. Olsen JH, Melbye M. Risk for subsequent cancer after diagnosis of basal cell carcinoma. A population-based, epidemiologic study. Ann Intern Med 1996;125:815-21.

144. Goldberg LH. Basal cell carcinoma as predictor for other cancers. Lancet 1997;349:664-5.

145. Mikhail GR, Nims L.P, Kelly AP Jr, et al. Metastatic basal cell carcinoma. Review, pathogenesis and report of two cases Arch Dermatol 1977;113:1261-9.

146. Beadles CF. A case of multiple malignant growths. Trans Pathol Soc London 1894;45:176-81.

147. Spies JW. Adenoid cystic carcinoma. Arch Surg 1930:21:365-404.

148. von Domarus HV. Stevens PJ. Metastatic basal cell carcinoma: report of five cases and review of 170 cases in the literature..J Am Acad Dematol 1984;10:1043 60 . 
149. Paver $\mathrm{K}$, Poyzer $\mathrm{K}$, Burry $\mathrm{N}$ et al. The incidence of basal cell carcinoma and their methstases in Australia and New Zealand [letter]. Australas I Derrmatol 1973;14:53.

150. Cotran RS. Metastasizing basal cell carcinomas. Cancer 1961;14:1036-40.

151. Lo JS, Snow SN, Reizner GT, et al. Metastatic basal cell carcinoma: Report of twelve cases with a review of the literature. I Am Acad Dermatol 199:24:715-9.

152. Randle HW, Roenigk RK. Characteristics of giant basal cell carcinoma In:Roenigk RK, Roenigk. HH. Jr eds. Surgical Dermatology: Advances in Curtent Practice. St. Louis: Mosby 1993;93-100.

153. Blewitt $\mathbb{R} W$. Why does basal cell carcinoma metastasize so rarely? Int I Dermatol 1980;19:1446.

154. Schuller DE, Berg JW, Sherman G et al. Cutaneous basosquamous carcinoma of the head and neck: a comparative analysis. Otolaryngol Head Neck Surg 1979;87:420-7.

155. Borel DM. Cutaneous basosquamous carcinoma. Review of the literature and report of 35 cases. Arch Pathol 1973;95:293-7.

156. Kanitakis J, Euvrard S, Bourchany D, et al. Expression of the nm23 metastasis-suppressor gene product in skin tumors. J Cutan Pathol 1997;24:151-6.

157. Goldberg LH. Basal cell carcinoma. Lancet 1996;347:663-7.

158. Lindelof $\mathrm{B}$, Sigurgeirsson $\mathrm{B}$, Wallberg $\mathrm{P}$, at al. Occurrence of other malignancies in 1973 patients with basal cell carcinoma. I Am Acad Dermatol 1991;25:245-8.

159. Skin Cancer Prevention Study Group. Risk of subsequent basal cell carcinoma and squamous cell carcinoma of the skin among patients with prior skin cancer. JAMA 1992;267(24);3305-10.

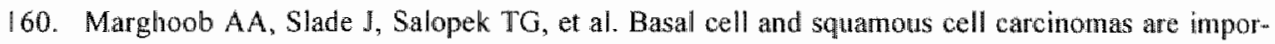
tant risk factors for cutaneous malignant melanoma: screening implications. Cancer 1995;75 supp 2:707-14.

161. Evans RD, Kopf AW, Lew RA, et al. Risk factors for the development of malignant melanoma. I. Review of case-control studies. J Dermatol Surg Oncol 1988;14:393-408.

162. Einspahr J, Alberts DS, Aickin M, et al. Expression of 553 protein in actinic keratosis, adjacent, normal-appearing and non-sun-exposed human skin. Cancer Epidemiol Biomarkers Prew $1997 ; 6: 583-7$.

163. Green A, Battistutta D. Incidence and determinants of skin cancer in a high-risk Australian polulation. Int J Cancer 1990;46:356-61.

164. Kricker $A_{*}$ English DR, Randell PL et al. Skin cancer in Geraldton, Western Australia: a survey of incidence and prevalence. Med J Aust 1990;152:399-407.

165. Frost CA, Green AC. Epidemiology of solar keratoses. Br J Dermatol 1994;131:455-464.

166. Thompson SC, Jolley D, Marks R. Reduction of solar keratoses by regular sunscreen use. N Engl $J$ Med 1993;329:1147-51.

167. Naylor MF, Boyd A, Smith DW, et al. High sun protection factor sunscreens in the suppression of actinic neoplasia. Arch Dermatol 1995;131:170-5.

168. Goldsmith LA, Koh HK, Bewerse BA. Full proceedings from the National Conference to Develop a National Skin Cancer Agenda. American Academy of of Dermatology and Centers for Disease Control and Prevention. Washington, DC, April 8-10 1995, J Am Acad Dermatol 1996;35:748-56.

169. Jaffe D, Kaplan DL. Aquired telangiectasia of the ear: predictive value for cutaneous malignancies. J Gerilatr Dermatol 1996:4:206-9.

170. American Cancer Society. Guidelines for the Cancer-Related Checkup: An Update. Atlanta, Ga: American Cancer Society; 1993.

171. Elwood JM. Screening and early diagnosis for melanoma in Australia and New Zealand. In: Cancer Screening: New York Cambridge University Press, 1990. 
172. Federman DG, Concalo J, Caralis PV, et al. Screening for skin cancer in primary care settings. Arch Dermatol 1997:133:1423-5.

173. Leffell DJ, Brash DE Sunlight and skin cancer. Sci Am 1996;275:52;356-9.

174. Stanford DG, Georgouras KE, Pailthorpe MT. The effect of laundering on the sun protection afforded by a summer weight garment. I Eur Acad Derm Venerol 1995:5:28-30.

175. Naylor MF, Famer KC. The case for sunscreens. A review of their use in preventing actinic damage and neoplasia. Arch Dematol 1997;133:1146-54.

176. Roberts LK, Beasley DG. Commercial sumscreen lotions prevent ultraviolet-radiation-induced immune suppression of contact hypertensitivity. I Invest Dermatol 1995;105:339-44.

177. Stern RS, Weinstein MC, Baker SG. Risk reduction for nonmelanoma skin cancer with childhood sunscreen use. Arch Dermatol 1986;122:537-45.

178. Attanthaswamy HN, Loughlin $\mathrm{SM}_{2}$ Cox $\mathrm{P}$, et al. Sunlight and skin cancer: Inhibition of $\mathrm{p} 53$ mutations in UV-irradiated mouse skin by sunscreens. Nature Med 1997,5:510-14.

179. Robinson JK, Rademaker AW. Relative importance of prior basall cell carcinomas, continuing, sun exposure, and circulating $T$ lymphocytes on the development of basal cell carcinoma. $J$ Invest Dermatol 1992;99:227-31.

180. Marks $R$, Foley $P A$, Jolley $D$, et al. The effect of regular sunscreen use on vitamin $D$ levels in an Australian popullation. Arch Dermatol 1995;131:415-21.

181. Orfanos $\mathrm{CE}$, Zouboulis $\mathrm{CC}$, Almond-Roesler $\mathrm{B}$, Geilen $\mathrm{CC}$. Current use and future potential role of retinoids in dermatology. Drugs 1997;53:358-88.

182. Moon TE, Levine N, Cartmel B, Bangert JL. Retinoids in prevention of skin cancer. Cancer Lett $1997 ; 114: 203-5$.

183. Rubach BW, Schoenrock LD. Histological and climical evaluation of facial resurfacing using a carbon dioxide laser with the computer pattern generator. Arch Otolaryngol Head Neck Surg $1997,123: 929-34$.

184. Green HA, Drake L. Aging, sun damage, and sunscreens. Clin Plast Surg 1993;20:1-8. 
Chapter 2

\section{Pathogenesis of Basal Cell Carcinoma}




\subsection{Introduction}

Despite the frequency of $\mathrm{BCC}$, little is known about its molecular pathogenesis." The most commonly accepted theory of cutaneous carcinogenesis, involving a multistep process of initiation, promotion, and conversion, is based largely on experimental studies involving the induction of $\mathrm{SCC}{ }^{2}$. Whether this theory also applies to the development of BCC is unclear. Several studies suggest that BCC may develop in a different fashion:

First, it has not been possible to induce any significant number of BCC by UV exposure in animals. Second, $\mathrm{BCC}$, unlike $\mathrm{SCC}$, do not appear to arise from precursor lesions ${ }^{3}$ but rather appear de novo. Third, immunosuppression such as renal transplantation or PUVA ${ }^{4.5 .6}$ therapy lead to marked increases in SCC incidence but only modest increases in $\mathrm{BCC}$ growth. In the general population, $\mathrm{BCC}$ are four times more common than $\mathrm{SCC}$. In renal transplant patients, however, the ratio is reversed with $\mathrm{SCC}$ being three times more common than $\mathrm{BCC}$. Fourth, several clinical situations preferentially facilitate the occurrence of BCC. These include the epidermis that overlies dermatofibromas," as well as several congenital or genetic entities: nevus sebaceus, linear unilateral basal cell nevus with comedones, Bazex's syndrome, and nevoid basal cell carcinoma syndrome (NBCCS). 10,11,12,13

\subsection{Molecular aspects of carcinogenesis}

All cancers involve the disruption of the normal constraints on cell proliferation or cell death. Cells normally have five options. These include renewal or proliferation, terminal differentiation, quiescence, senescence and apoptosis. Many factors interact with cell cycle regulators to direct the cell toward these different options. Tumor suppressor genes play a pivotal role in this process. Alterations in these genes may limit the options that cells have and thus play a significant role in the multistep process of carcinogenesis. ${ }^{14}$

It is generally accepted that carcinogenesis is related to the accumulation of genetic damage in somatic cells. It is a multistep ${ }^{\text {is }}$ process that requires both initiating, promoting and progression substances for the development of cancer. ${ }^{16.17}$ Tumorigenesis involves activation of proto-oncogenes and inactivation of tumor-suppressor genes and is characterized by an accumulation of genetic abnormalities. ${ }^{18}$

Mutations in tissue cells accumulate continuously throughout life, beginning in the embryo. In several experimental systems, one or even two genetic alterations may be enough to alter a cultured cell's phenotype to that of a cancer cell. 19 It has been suggested that mutations in at least four to five genes are required for the formation of a malignant tumor. ${ }^{20}$

The cellular and molecular processes that occur during the initial carcinogen-cell interaction and the onset of tumor growth are largely unknown. However, the carcinogenic process begins when a carcinogenic agent, radiation or chemical, damages the cellular DNA, which then leads to a cascade of events including DNA repair, mutation, and transformation. Cells can become mutated by a variety of agents that damage 
DNA. ${ }^{2122}$ The carcinogenic potential of damage to DNA strongly depends on the efficacy of DNA repair systems. ${ }^{23}$

Some individuals are genetically predisposed to a particular type of cancer. According to Knudson's 'two-hit' hypothesis, hereditary forms of cancer must have a simple relationship. ${ }^{24}$ Individuals inheriting an abnomal allele are predisposed to cancer because every cell already harbors one abnormal allele. One nomal allele would prevent cancer. A 'multi-hit' hypothesis, in which tumor promotor genes (oncogenes) as well as suppressors play essential roles, seems to be more prominent for most tumor types. Individual suppressor genes may follow the two-hit paradigm, but this is definitely not appropriate as a full description of the genetic changes in tumorigenesis. For instance in nonhereditary colorectal carcinoma, tumors appear to arise as a result of the mutational activation of oncogenes coupled with the mutational inactivation of tumor suppressor genes.

Based on Knudson's work, many of the genes implicated in the rare familial syndromes have now been shown to be important in much more common sporadic tumors. To date two such genes have attracted interest in NMSC: 553 and a putative tumor suppressor gene on chromosome 9 responsible for NBCCS. Loss of heterozygosity (LOH) on chromosome $9 \mathrm{q} 22$, is the most frequent genetic alteration in $\mathrm{BCC}$, and its causative agent is unknown. Mutations of the tumor suppressor gene p53 are often found in NMSC and pre-invasive lesions, like actinic keratosis (AK). The type of mutations detected in the p53 gene strongly indicate UV light as the initiating and promoting agent in skin cancer development. Despite the huge amount of information available in the literature on molecular markers of skin cancers, much remains to be uncovered about the progression of genetic events that separate normal sun-exposed epidermis from skin cancer.

\subsection{Molecular aspects of $\mathrm{BCC}$ carcinogenesis}

Carcinogenesis represents the sum of a complex of sequential and simultaneous (biochemical) events that eventually lead to the occurrence of skin cancer. These events, initiated by UV radiation, include the formation of DNA photoproducts: DNA repair; mutation of proto-oncogenes and tumor suppressor genes. The introduction of mutations in keratinocytes involves a series of molecular events, beginning with the reaction of UV with cellular DNA. The wavelengths of UVB that are carcinogenic for human cells correspond to the absorption spectrum of DNA. ${ }^{25}$ If, as a hypothical, we assume that the skin can correctly repair $99.99 \%$ of all UV-induced DNA-damage, DNA repair may keep up reasonably well with the acquisition of new UV-induced damage. Under these (optimal) conditions, cumulation of mutations will be occurring at some low baseline rate for each hour in the sun. ${ }^{26}$ It has been shown that DNA repair capacity declines with age and is reduced in young patients with $\mathrm{BCC}$ and those with a family history of NMSC. A combination of reduced DNA repair capacity and overexposure to sunlight was associated with an increased risk of $\mathrm{BCC}$ as high as 10 -fold in one subject group, but differences in DNA repair capacity became less significant with increasing age. $^{27}$ 


\subsubsection{Oncogenes}

Oncogenes, originally discovered through the study of critical genes in the acutely transforming retroviruses, ${ }^{28}$ have the ability to transform cells from normal to uncontrolled growth. They are found in the genetic counterpart of normal cells, where they are called proto-oncogenes. Oncogenes lead to the development of a cancer by stimulam ting proliferation. Cellular proto-oncogenes can be activated by both point mutations and chromosomal translocations, suggesting that there may be a direct link between exposure to agents that damage DNA and genetic change leading to malignancy. ${ }^{29}$ Each of these alterations can have an effect on biochemical function or protein products. Characteristically these mutations have a dominant effect; only one of the cell's two copies is required to undergo mutation. Oncogenes such as ras act as positive growth regulators. Mutations at various codons lead to a protein that is permanently activated, with the result that in many cell types a switch to cellular hyperproliferation occurs. $^{30}$

\section{Oncogenes in $B C C$}

Ras oncogene mutations were suggested to be common in NMSC. ${ }^{31}$ More recent work has, however, yielded different results, showing a low frequency of mutation in NMSC. ${ }^{32}$ In human BCC analysis of proto-oncogenes reveals that expression of $\mathrm{c}-f \circ$, c-myc, Ha-ras and $\mathrm{N}$-ras are the same as in normal skin, ${ }^{33}$ although signature mutations from UVB have been found in ras genes in some human $\mathrm{BCC} .{ }^{34}$

The bcl-2 protein increases cell longevity and reduces apoptosis and expression of the proto-oncogene bcl-2 was shown in 15 out of $15 \mathrm{BCC}$. The positive bcl-2 staining of $\mathrm{BCC}$ tumor cells supports the hypothesis that $\mathrm{BCC}$ originate from the basal layer of the epidermis. The bcl-2 expression of $\mathrm{BCC}$ also suggests a neoplastic transformation caused by extended cell survival rather than increased cell proliferation. ${ }^{35}$ Recently expression of bcl-2, was found to be the highest in indolent-growth $\mathrm{BCC}$ and weakest in the aggressive-growth variants. Therefore it was suggested that bcl-2 expression might be integral to both pathogenesis and biological behavior of $\mathrm{BCC} .{ }^{36}$

\subsubsection{Tumor suppressor genes}

Tumor suppressor genes, when mutated or deleted, lose their negative influence on tumor growth control. In contrast to oncogenes, tumor suppressor genes are negative growth regulators, that block transformation and maintain the cell's normal phenotype. Their function is to control cellular mechanisms such as cell proliferation and differentiation. Several cloned genes such as retinoblastoma $(\mathrm{Rb})$ gene, ${ }^{37} \mathrm{p} 53,{ }^{38.39}$ the deleted in colon carcinoma (DCC) gene, ${ }^{40}$ the mutated in colorectal carcinoma (MCC) gene, the neurofibromatosis type I (NF-1) gene," the adenomatous polyposis coli (APC) gene, the Wilms' tumor gene (WT-1), ${ }^{42}$ and $\mathrm{K}-\mathrm{rev}-1 / \mathrm{rap}-1 \mathrm{~A}^{43}$ are known to function as tumor suppressors. Classically, mutations in oncogenes tend to be dominant, while those in tumor supressor genes are recessive. 


\subsubsection{P53, apoptosis and $B C C$}

The role of $\mathrm{p} 53$ (53-kd phosphoprotein) in the control of many cellular functions. including cell cycle, programmed cell death (apoptosis), cellular differentiation, and perhaps DNA-repair, provides an easy target for neoplasia. This protein plays a central role in the cellular response to DNA damage, rapidly accumulating in the nucleus of injured cells and causing a delay of the cell cycle in the $\mathrm{G} l$ period, that may provide additional time for DNA repair or cell ellimination by apoptosis. ${ }^{44}$

A failure in the apoptotic response after severe genomic damage could facilitate cell transformation and tumor development. Recently it was shown that, disturbances in either p53 or bcl-2 is sufficient to enhance skin tumor formation by suppressing apoptosis. 45

In renal transplant recipients, who have increased skin cancer incidence, a high prevalence of p53 immunoreactivity in premalignant and malignant skin lesions, supports a role for p53 protein in skin cancer. This could be caused by mutation of the p53 gene, inactivation, or failure of degradation of $\mathrm{p} 53$ protein. ${ }^{46}$

Mutations in the p53 gene have been detected in BCC. 77 .48 53 mutations occur in both $\mathrm{BCC},{ }^{490}$ and $\mathrm{SCC},{ }^{51}$ although the absolute rates of mutation vary between $10 \%$ and $90 \%$ in the various studies. ${ }^{32}$ The mutations tend to cluster in "hot spots" along the p53 gene that represent sites of inefficient repair of pyrimidine dimers. "The pattern of mutations, with $\mathrm{C} \rightarrow \mathrm{T}$ and $\mathrm{CC} \rightarrow \mathbb{T} \mathbb{T}$ base changes predominating, reflects the role of UVR-induced DNA damage in the pathogenesis.

Whether p53 mutations occur as an early event or a late event of carcinogenesis remains unclear. It may be difficult to clarify this, because the majority of BCC do not arise from precursor lesions but rather appear de novo. However, recently it has been shown that in the epidermis adjacent to BCC in chronically sun-exposed epidermis, p53 accumulation is detectable. ${ }^{55}$

Studies suggest that BCC commonly progress through inactivation of a single p53 allele, although others find mutations on both alleles. ${ }^{56}$ Microdissection of small parts of individual tumors showed $\mathrm{BCC}$ to be composed of a dominant cell clone and prone to genetic progression with appearance of subclones with a second or even thind p53 mutation. ${ }^{57}$ Sixty-nine \% of the BCC had lost a $9 \mathrm{q}$ allele, with the common area of loss surrounding the putative gene for NBCCS. Forty-four $\%$ of BCC had a mutated p53 allele. ${ }^{58}$ Mutation of $\mathrm{p} 53$ may produce a possible dominant protooncogene able to add malignant potential to tumors." This so-called "gain of function" p53 mutation could be the predominant mechanism of progression for $\mathrm{BCC}$. Alternatively, the well-established tumor suppressing function of p53 could be diminished by inactivation of a single allele. ${ }^{60}$ It has been suggested that chronic UV exposure is responsible for accumulation of $\mathrm{p} 53$ mutations and thus for late age BCC appearance, whereas acute UV exposure in childhood and adolescence leads to early skin cancer development in genetically susceptible individuals via a p53-independent pathway. ${ }^{\star 1}$

It is conceivable that p53-based gene therapy may one day be used in the treatment of skin tumors, given the key role of p53 in regulating cell division and differentiation. 


\subsection{Inherited predisposition of $\mathrm{BCC}$}

Patients with the NBCCS have multiple developmental malformations and a striking predisposition for $\mathrm{BCC}$. Especially after exposure to ionizing radiation, $\mathrm{BCC}$ appear with a very brief latency period. NBCCS maps to chromosome $9 \mathrm{q} 22.3$, and loss of heterozygosity at this site in both sporadic and hereditary $\mathrm{BCC}$ suggest that it functions as a tumor suppressor.

The deletion $9 \mathrm{q}$ in BCC seems to be independent of the race. ${ }^{62}$ The gene for NBCCS was recently cloned and is the human homologue (PTCH) of the Drosophila segment polarity gene. ${ }^{63,64}$ This gene, patched, is mutated in $\mathrm{BCC}$ of patients with NBCCS as well in sporadic $B C C^{65}$ and inactivation of this gene is probably a necessary, if not sufficient, step for $B C C^{60}$ In the future, delineation of the biochemical pathway in which patched functions may lead to rational medical therapy for BCC and possibly for other tumors associated with NBCCS.

\subsection{Immunosuppression and $\mathrm{BCC}$}

Patients with NMSC may be immunosuppressed. It has been reported that patients with large NMSC have decreased skin test reactions to common antigens, while those with smaller lesions exhibit normal responses. ${ }^{67}$ The effect of immunosuppression seems to be bigger for $\mathrm{SCC}$ than for $\mathrm{BCC}$ : immunosuppression such as renal transplantation or PUVA therapy lead to marked increases in SCC incidence but only modest increases in BCC growth. ${ }^{68}$ The prevalence and type of HPV infection in cutaneous lesions from PUVA-treated patients is similar to that previously reported in renal transplant-associated skin lesions. ${ }^{69}$

Langerhans cells, important because of their immunosurveillance, have been reported to be decreased in SCC, but normal or increased in $\mathrm{BCC}{ }^{70}$ Although the number of Langerhans cells surrounding BCC may be unaltered, there may still be perturbations in these cells which could be of immunologic significance. ${ }^{71}$ Recently a novel pathway by which UV light can contribute to the ability of a skin cancer to escape form immune attack by cytotoxic T-lymphocytes was reported. BCC tumor cells express CD95L (Fas Ligand). which is associated with peritumoral T-lymphocytes that are undergoing apoptosis. $^{72}$

Immunologic approaches to treating skin cancers so far have concentrated on nonspecifically stimulating immune cells that infiltrate these tumors, but induction of specific immune responses against these tumors with antitumor vaccins has received little attention yet. Future strategies may employ means to reverse UV-induced immunosuppression by using anti-inflammatory agens, biologicals that accelerate DNA repair or prevent the generation of immunosuppressive cytokines, and specific immunotherapy with tumor antigens. 


\subsection{Basement membrane, Hemidesmosome and Metalloproteinases}

The stroma of BCC appears to be important not only in the induction, but also in the survival of BCC. Transplantation of a BCC in the absence of its stroma often fails. ${ }^{73}$ This marked stromal dependency may explain why $\mathrm{BCC}$ so rarely metastisize. $\mathrm{BCC}$ tumor invasion may occur due to a combination of the proteolytic degradation of the epidermal basement membrane along with the diminished synthesis of several basement membrane components by the tumor cells.

Decreased protein levels of basement membrane components in $\mathrm{BCC}$ are due at least partially to a downregulation of basement membrane mRNA species. ${ }^{74}$ These alterations may lead to an incompetent basement membrane that facilitates invasion by $\mathrm{BCC}$ into tissues.

In $\mathrm{BCC}$ components of the hemidesmosome-anchoring filament complex are not synthesised or assembled properly in $\mathrm{BCC} .{ }^{75}$ These alterations of the adhesion structures may be the cause of the peritumoral lacunae. Transcripts for metalloproteinase- 1 (interstitial collagenase) were demonstrated densely in stromal cells among BCC tumor masses, and those for metalloproteinase- 3 (stromelysin-1) were detected only in more advanced cases. The two metalloproteinases were produced by stromal cells according to the tumor invasion process. Nodular BCC demonstrated the gene expression for both metalloproteinases but superficial $\mathrm{BCC}$ did not present any transcripts for them. ${ }^{\text {.6 }}$ Aggressive $\mathrm{BCC}$ can produce stromelysin- 3 as well. ${ }^{77}$ 


\section{References}

1. Grossman D, Leffell DJ. The molecular basis of nonmelanoma skin cancer. Arch Dermatol $1997: 133: 1263-70$.

2. Yuspa SH. Cutaneous chemical carcinogenesis. J Am Acad Dermatol 1986; 14:49-55.

3. Marks $R$, Rennie $G$, Setwood $T$. The relationship of basal cell carcinomas and squanous cell carcinonass to sollar keratoses. Arch Dermatol 1988;124:1039-42.

4. Stem RS, Lange R. Non-melanoma skin cancer occurring in patients treated with PUVA five to ien years after first treatment. I Invest Dermatol 1988;91:120-4.

5. Van Praag MCG, Bouwes Bavinck JN, Bergman W, et al. PUVA keratoses. A clinical and histologic entity associated with an increased risk of nonmelanoma skin cancer. $J$ Am Acad Dermatol 1993;28:412-7.

6. Lever LR and Farr P’M. Skin cancers or premalignant lesions occur in half of highth-dose PUVA

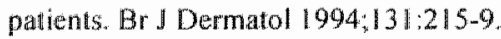

7. Scotto $J$, Fears TR, Fraumeni JF. Incidence of nonmelanoma skin cancer in the United States. Publication No. 83-2433. Bethesda, MD: National Institutes of Health, 1983.

8. Gupta AK, Cardella CJ. Cutaneous malignant neoplasms in patients with renal transplants. Arch Dermatol 1986;122:1288-93.

9. Buselmeier TJ, Uecker JH. Invasive basal cell carcinoma with metaplastic bone formation associated with a longstanding dermatofibroma. J Cutan Pathol 1979;6:496-500.

10. Domingo J, Helwig EB. Malignant neoplasms associated with nevus sebaceus of Jadassohn. I Am Acad Dermatol 1979;1:545-56.

11. Bleiberg J, Brodkin RH. Linear unilateral basal cell nevus with comedones. Arch Dermatol 1969;100:186-90.

12. Melita VR, Potdar R. Bazex syndrome. Follicular atrophoderma and basal cell epitheliomas. Int J Dermatol 1985;24:444-6.

13. Gorlin R. Nevoid basal-cell carcinoma syndrome. Medicine (Baltimore) 1987;66:98-113.

14. Smith KJ, Barrett TL., Smith WF, Skelton HM. A review of tumor suppressor genes in cutaneous neoplasms with emphasis on celll cycle regulators. An J Dermatopathol 1998;20(3):302-13.

15. DiGiovanni J. Multistage carcinogenesis in mouse skin. Pharmacol Ther $1992 ; 54: 63-128$.

16. Agarwal R, Mukhtar H. Cutaneous chemical carcinogenesis. In: Mukhtar H (ed). Pharmacology of the Skin. CRC Press, Boca Raton, Florida, 1991, pp 371-87.

17. Whalen GF. Solid tumors and wounds: transformed cells misunderstood as injured tissue? Lancet 1989;336:1489-92.

18. Vogelstein B, Kinzler $\mathrm{KW}$ : The multistep nature of cancer (review) Trends Genet 1993;9:13841 .

19. Weinberg RA. Oncogenes, tumor suppressor genes, and cell transformation: trying to put it all together, In: Brugge J, Curran T, Harlow E, MoCormick F (eds.) Origins of Human Cancer. Cold Spring Harbor Laboratory Press, Cold Spring Harbor, 1991, pp 1-16.

20. Fearon ER, Vogelstein B. A genetic model for colorectal tumorigenesis. Cell 1990;61:759-67.

21. Anonymous Sunlight, DNA repair, and skin cancer. Lancet 1989:1:1362-3.

22. Stoler AB. Genes and cancer. Br Med Bull 1991;47:64-75.

23. Setlow RB. Repair deficient human disorders and cancer. Nature 1978;271:713-7.

24. Knudson A. Genetic events in human carcinogenesis. In: Brugge J, Curran T, Harlow E, McCormick $\mathrm{f}$ (eds.). Origins of Human Cancer. Cold Spring Harbor Laboratory Press, Cold Spring. Harbor, 1991, pp 17-36.

25. Sutherland BM. Delihas NC, Oliver RP, et al. Action spectra for ultraviolet-induced transformation of human cells to anchorage-independeny growth. Cancer Res 1981;41:2211-14. 
26. Naylor MF. Erythema, skin cancer risk, and sunscreens. Arch Dematol 1997; 13:373-5.

27. Wei Q. Matanoski GM, Farmer ER, et al. DNA repair and aging in basal cell carcinoma: a molecular epideniology study. Proc Natl Acad Sci USA 199;,90:1614-18.

28. Varmus HE. The Molecular genetic of cellular ancogenes. Amr Rev Genet 1984;18:553-612

29. Suarez HG. Activated oncogenes in human tumors. Anticancer Res 1989;9:1331-4.

30. Bos JL. Ras oncogenes in human cancer: a review. Cancer Res 1989;49:4682-9.

31. Campbell $\mathrm{C}$, Rees JL. The role of ras gene mutations in murine and human skin carcinogenesis. Skin Cancer 1993:8:245-54.

32. Campbell D, Quinn AC, Rees $J L$. Codon 12 Harkey-ras mutations are rare events in nonmelannoma human skin cancer. Br J Dermatol 1993:128:111-4.

33. Ogiso $\mathrm{Y}$, Oikawa $\mathrm{T}$, Kondo $\mathrm{N}$, et al. Expression of protooncogenes in normal and numor tissues of human skin. I Invest Dermatol 1988;90:841-4.

34. Wan der Schroeff JG, Evers LM, Boot AJM, Bos JL. Ras oncogene point mutations in basall cell carcinomas and squamous cell carcinomas of the human skin. J Invest Dermatol 1990;94:423-5.

35. Verhaegh ME, Sanders CJ, Arends JW, Neumann HA. Expression of the apoptosis-suppressing protein Bcl-2 in non-melanoma skin cancer. Br J Dermatol 1995;132:740-4.

36. Crowson AN, Magro CM, Kadin ME, Stranc M. Differential expression of the bel-2 oncogene in human basal cell carcinoma. Hum Pathol 1996;27:355-9.

37. Friend SH, Bernards R, Rogelj S, et al. A human DNA segment with the properties of the gene that predisposes to retinoblastoma and osteosarcoma. Nature 1986;323:643-646.

38. Baker SJ, Fearon ER, Nigro JM, et al. Chromosome 17 deletions and $p 53$ gene mutations in colorectal carcinomas. Science 1989;244:217-221.

39. Batsakis JG, El-Naggar AK. P53: fifteen years after discovery. Adw Anat Pathol 1995;2:71-88.

40. Fearon ER, Cho KR, Nigro JM, et al. Identification of a chromosome $18 \mathrm{q}$ that is altered in colorectal cancers. Science 1990;247:49-56.

41. Cawton RM, Weiss R, Xu G, et al. A major segment of the neurofibromatosis type I gene: cDNA sequence, genomic structure, and point mutations. Cell 1990;62:193-201.

42. Gessler M, Poustka A, Cavenee W, et al. Homozygous deletion in Wilms ${ }^{*}$ tumors of a zincfinger gene identified by chromosome jumping. Nature 1990;343:774-8.

43. Schaefer R, lyer J, Eten E, Nirkko AC. Partial reversion of the transformed phenotype in HRAS* transfected tumorigenic cells by transfer of a human gene. Proc Natl Acad Sci USA 1988;85:1590-4.

44. Lowe $\mathrm{SW}$, Schmitr EM, Smith SW, et al. P53 is required for radiation-induced apoptosis in mouse thymocytes. Nature 1993;362:847-9.

45. Wikonkal NM, Berg RJ, van Haselen CW. Bcl-2 vs p53 protein expression and apoptotic rate in human nonmelanoma skin cancers. Arch Dermatol 1997;133:599-602.

46. Gibson GE, O'Grady A, Kay EW, et al. P53 tumor suppressor gene protein expression in premalignant and maligmant skin lesions of kidney transplant recipients. I Am Acad Dermatol $1997 ; 36: 924-31$.

47. Rady P. Scinicariello, Wagner RF Jr, Tyring SK. P53 mutations in basal cell carcinomas. Cancer Res 1992;52:3804-6.

48. Moles JP. Moynet C, Guillat B, et al, P53 gene mutations in thuman epithelial skin cancers. Oncogene 1993:8:583-8.

49. Kubo $Y$, Urano $Y$, Yoshimoto $K_{\text {}}$, et al. P53 gene mutations in human skin cancers and precancerous lesions: comparison with immunohistochemical analysis. J Inwest Dermatol 1994:102:4404.

50. Camplbell C, Quinn AG, Angus B, Rees JL. The relation between p53 mutation and p53 immunostaining in non-melanoma skin cancer. Br J Dermatol 1993; 129:235-41. 
51. Brash DE, Rudolph JA, Simon JA, et al. A role for sunlight in skin cancer: UV-induced p53 mutations in squamous cell carcinoma. Proc Nat Acad Sci USA 1991;88:10124-8.

52. Rees 3. Genetic alterations in non-melanoma skin cancer. J Invest Dermatol 1994;103:747-50.

53. Ziegler A, Leffell DJ, Kunalit $S$, et all. Mutation hotspots due to sumlight in the p53 gene of nonmelanoma skin cancers. Proc Natl Acad Sci USA 1993;90:4216-20.

54. Miller SJ. Biology of basal cell carcinoma (part II). J Am Acad Dermatol 1991;24:161-75.

55. Urano $Y$, Asano $T$, Yoshimoto $K$, et al. Frequent $p 53$ accumulation in the chronically sunexposed epidermis and clonal expansion of p53 mutant cells in the epidermis adjacent to basal cell carcinoma. J Invest Dermatol 1995:104:928-32.

56. Basset-Seguin N, Moles JP, Mils $\mathrm{V}$, et al. TP53 tumor suppressor gene and skin carcinogenesis. Invest Dermatol 1994;103:102 6.

57. Ponten J. Berg C, Ahmadian A, et al. Molecular pathology in basal cell cancer with 053 as a genetic marker. Oncogene 1997;15:1059-67.

58. Van der Riet $P$, Karp D, Farmer $E$, et al. Progression of basal cell carcinoma through loss of chromosome $9 q$ and inactivation of a single p53 allete. Cancer Res 1994:54:25-7.

59. Dittmer $\mathrm{D}$, Pati $S$, Zambetti $\mathrm{G}$, et al. Gain of function mutations in p53. Nat Genet 1993:4:42-6.

60. Levine AS, Monard J, Finlay CA. The p53 tumor suppressor gene. Nature 1991;351:453-6.

61. D'Errico M, Calcagnile AS, Corona R, et al. P53 mutations and chromosome instability in basal cell carcinomas developed at an early or late age. Cancer Res 1997:57:747-52.

62. Konishi $K$, Kiyofumi $Y$, Ishizaki $K$, et all. Analysis of $p 53$ gene mutations and loss of heterozygosity for loci on chromosome $9 \mathrm{q}$ in basal cell carcinoma. Cancer Letters 1994;79:67-72.

63. Chidambaram A, Goldstein AM, Gailani MR, et al. Mutations in the human homologue of the Drosophila patched gene in Caucasian and African-American nevoid basal cell carcinoma syndrome patients. Cancer Res 1996;56:4599-601.

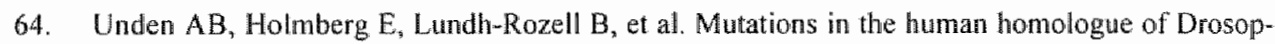
hila patched (PTCH) in basal cell carcinomas and the Gorlin syndrome: different in vivo mechanisims of PTCH inactivation. Cancer Res 1996;56:4562-5.

65. Aszterbaum M, Rothman $A$, Johnson $\mathbb{R}$, et al Identification of mutations in the human PATCHED gene in sporadic basal cell carcinoma an in patients with the basal cell nevus syndrome. $J$ Invest Dermatol 1998;110:885-8.

66. Gailani MR, Bale AE. Developmental genes and cancer: role of patched in basal cell carcinoma of the skim. INatl Cancer Inst 1997;89:1103-9.

67. Weimar VM, Ceilley RI, Goeken JA. Cell-mediated immunity in patients with basal and squamous cell skin cancer. J Am Acad Dermatoll 1980;2:143-7.

68. Preston DS, Stern RS. Nonmelanoma cancers of the skin. N Eng Med 1992;327:1646.

69. Harwood CA, Spink PJ, Surentheran $T$, et al. Detection of Human Papillomavarus DNA in PUVA-associated non-melanoma skin cancers. J Invest Dermatol 1998;111:123-7.

70. Murphy $G$, Krasinski P, Myzak L, et al.Local immune response in basal cell carcinoma.Characterization by transmission electron microscopy and moloclonal anti-T6 antibody. II Am Acad Dermatol $1983 ; 8: 477$.

71. Azizi $\mathbb{E}$, Bucana $C$. Goldberg $L$, et al. Perturbation of epidermal Langerhans cells in basal cell carcinomas. Am J Dermatopathol 19:87;9:465.

72. Gutierrez-Steil $C$, Wrone-Smith T, Sun $X$, et al. Sunlight-induced basal cell carcinoma tumor cells and ultraviolet B-irradiated psoriatio plaques express Fas Ligand (CD95L). I Clin Invest 1998:101:33-9.

73. Pawlowski A, Haberman H. Heterotransplantation of human basal cell carcinoma in "nude" mice. Invest Dermatol 1979;72:310.

74. Chopra A, Maitra B, Korman NJ. Decreased mRNA expression of several basement membrane components in basal cell carcinoma. J Invest Dermatol 1998:1 10:52-6. 
75. Bahadaron $P$, Perrin $C$, Aberdam $D$, wt all. Altered expression of the hemidesmosome-anchoring flament complex proteins in basal cell carcinoma: possible role in the origin of peritumorat lacunae. Br J Dermatol 1997;136:35-42.

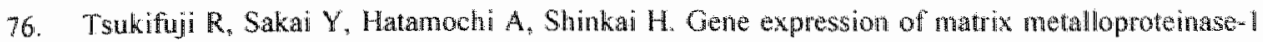
(interstitial collagenase) and matrix metalloproteinase-3 (stromalysin-1) in basal cell carcinoma by in situ lhybridization using chondroitin ABC lyase. Histochem J 1997;29:401-7.

77. Unden $\mathrm{AB}$, Sandstedt $\mathrm{B}$, Bruce $\mathrm{K}$, ef al. Stromelysin-3 $\mathrm{mRNA}$ associated with myofibroblasts is overexpressed in aggressive basal cell carcinoma and in dermatofibroma but not in dermatofibrosarcoma. J Invest Dermatol 1996:107:147-53. 

Chapter 3

\section{The treatment of basal cell carcinoma with Mohs' Micrographic Surgery}

G.A.M. Krekels.

Parts of this chapter have been published:

*J Eur Acad Derm Venereol 1996:6:217-225. Treatment of 208 extensive basal cell carcinoma with Mohs' Micrographic Surgery. H.A.M. Neumann, G.A.M. Krekels, M.E.J.M. Verhaegh.

* Ned. Tijdschrift voor Dermatologie \& Venereologie 1996;6:90-93. Mohs Micrografische Chirurgie in Nederland. G.A.M. Krekels, M.E.J.M. Verhaegh, H.A.M. Neumann. *Oncologische Dermatochirurgie 1996, Universiteit Maastricht. Beljaards \& Neumann.

*NTVG 1997;41:524-529 Micrografische chirurgie volgens Mohs als behandeling voor recidief van basalecelcarcinoom. A.A.W. Baardwijk, M.E.J.M Verhaegh, G.A.M. Krekels, A.H.M. Vermeulen, H.A.M. Neumann. 


\subsection{History}

In the 1930 's, Dr. Frederic Mohs (University of Wisconsin), developed a "chemosurgical" technique for tumor identification and removal". He showed that basal cell carcinoma (BCC) in particular could exhibit irregular outgrowths that were often missed by clinical visualization and palpation. ${ }^{2}$

While experimenting with various irritants, a $20 \%$ zinc chloride solution was injected and caused tumor necrosis. Microscopic examination however revealed perfect preservation of histologic appearance. The microscopic structure of the killed tissue was retained the same as if the tissue had been excised and immersed in a fixative solution. This observation of in situ fixation suggested the idea that it might be the basis for a method by which cancers can be excised under complete microscopic control.

The idea of excising the tumor layer by layer and microscopically examining the entire undersurface of each horizontally-cut layer by the systematic use of frozen sections, was conceived. Mohs reasoned that tumors treated this way would have very little if any opportunity to metastasise from surgically induced disruption. The induction of tumor metastases by surgical incision has never been confirmed; and the frequency of metastatic disease for non-melanoma skin cancers was not altered by omission of the presurgical zinc chloride application. The use of this chemosurgery (or fixed-tissue Mohs' surgery) on humans was subject to a number of drawbacks. It required time for adequate tissue penetration and was painful for the patient. In addition, depth of penetration was often unpredictable and difficult to control. Because the fixative was a foreign substance, the body reacted by an intense inflammatory response and even fever. This fixed tissue technique often required several days for completion.

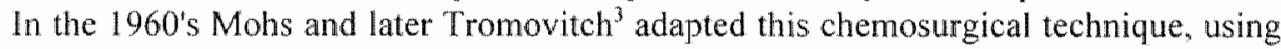
local anesthesia, and cutting fresh-tissue frozen sections. Basically, this is the same technique as the fixed-tissue technique previously discussed exept that the chemical fixative is not applied to the skin tumor. A tangential layer of unfixed (or fresh) tissue is excised, which includes gross tumor as well as a surrounding (small) margin of normal tissue. As with the fixed tissue technique, a map is drawn to correspond to the surgical defect. This fresh-tissue technique (FFT) has the advantages of eliminating most of the pain previously associated with zine chloride application, it reduces costs, and it is less time-consuming because multiple layers can be removed in a single session. Also, since the wound has no foreign material on it after complete removal of the tumor, it may be immediately repaired. FFT offers more advantages than the fixedtissue technique and is currently almost uniformly used. A distinct advantage of the fixed-tissue Mohs surgery is however the ability of the fixative to penetrate bone. This allows for an accurate assessment of the removed bone for the presence of tumor ${ }^{4}$ Use of the fixed-tissue technique is now reserved for special circumstances thought to benifit from fixation such as malignant melanoma excision and bone invasion. In 1985 the technique was offically changed to "Mohs micrographic surgery".

The micro is from microscope, and graph refers to a layer-by-layer pictorial representation of the tumor configuration. Nowadays there is an American College of Mohs' Micrographic Surgery and Cutaneous Oncology and a European Society for Micrographic Surgery. 


\subsection{Introduction}

The incidence of the most common malignancy in humans, skin cancer, ${ }^{5}$ is rapidly increasing worldwide. ${ }^{6.7}$ For non-melanoma skin cancer (BCC and squamous cell carcinoma, or SCC) the incidence in the USA is as high as that of all other cancers combined. Currently, according to the Skin Cancer Foundation, one in six Americans will develop skin cancer during his or her lifetime." In the Netherlands, approximately $18.000 \mathrm{BCC}$ were diagnosed in 1994. Currently an estimated number of $29.000 \mathrm{BCC}$ are diagnosed annually. "With an expected increase of $2.700 \mathrm{BCC}$ annually, it has become a significant public health problem. Since these figures are based on pathologically confirmed diagnoses and exclude untreated lesions or lesions treated without a biopsy, they are conservative estimates. Approximately $80 \%$ of BCC are found on the head and neck. "Although rarely metastatic," the tumor can cause significant local destruction, disfigurement and loss of quality of life.

$\mathrm{BCC}$ follows the path of least resistance. ${ }^{12}$ It is for this reason that invasion of bone, cartilage, and muscle is not common and is a late phenomenon. $\mathrm{BCC}$ usually do not invade the subcutaneous fat because of its poor blood supply. If a BCC does invade fat, it travels down the fibrous septae that contain the blood vessels of this layer of the skin. When BCC encounters these structures it will spread along the perichondrium, periosteum, or fascia. This can result in an iceberg phenomenon and in part explains the difficulty in management of and higher than expected recurrence rate for $\mathrm{BCC}$ of the eyelid, ear, nose, scalp. On the nose, the BCC may grow along the perichondrium until it comes to an area of cartilages and then may extend into the plane of soft tissue separating the cartilages. In the inner canthal area, $\mathrm{BCC}$ can spread in the periosteum posteriorly along the medial wall of the orbit. $\mathrm{BCC}$ can also infiltrate along the periosteum down into the external ear canal and can spread in this plane in the temple and malar areas. Periosteal spread could in part explain the extensive subclinical spread of BCC sometimes seen in the temple region. BCC occasionally spread along vessels or by perineural invasion. Embryonic fusion planes (inner canthus, philtrum, nasolabial sulcus, periauricular area) offer little resistance to the penetration of $B C C$. and an iceberg phenomenon may be observed in which there is extensive subclinical spread of tumor. Because BCC grow slowly and rarely metastasize, they often don't get the respect they need. A physician may decide to repeatedly curette and electrodessicate a recurrent $\mathrm{BCC}$ because it does not appear to be deeply invasive and definitive therapy might disfugure the (young) patient. Alternatively the physician wants to spare an elderly patient the possible morbidity of a surgical procedure. In the past, these elderly patients where treated with radiation therapy. This is no longer the case. People not only live longer now, but they also usually enjoy a better quality of life and health. Consequently, an older individual must not be denied definitive surgery. A small tumor in an 85-year old, may become a large, foull-smelling tumor in 5 -years time. This approach ultimately can lead to the loss of an eye or nose or to the death of the patient. Bearing optimal treatment in mind a closer look at Mohs" Micrographic Surgery (MMS) is timely. MMS is one of multiple treatment options available for BCC (see Table 6 in Chapter 1). MMS has had its greatest application and success in the treatment of difficult $\mathrm{BCC}$ and $\mathrm{SCC}$. Over the last years, the list of indications 
for MMS has grown and this technique is now used for many other tumors than BCC. In the treatment of $B C C$ characteristics such as tumor histologic subtype, size. anatomic location, patient age, previous therapy, and other medical problems contribute to determining the optimal treatment plan for the individual patient and tumor. Only by taking into account all these factors, the best treatment can be chosen.

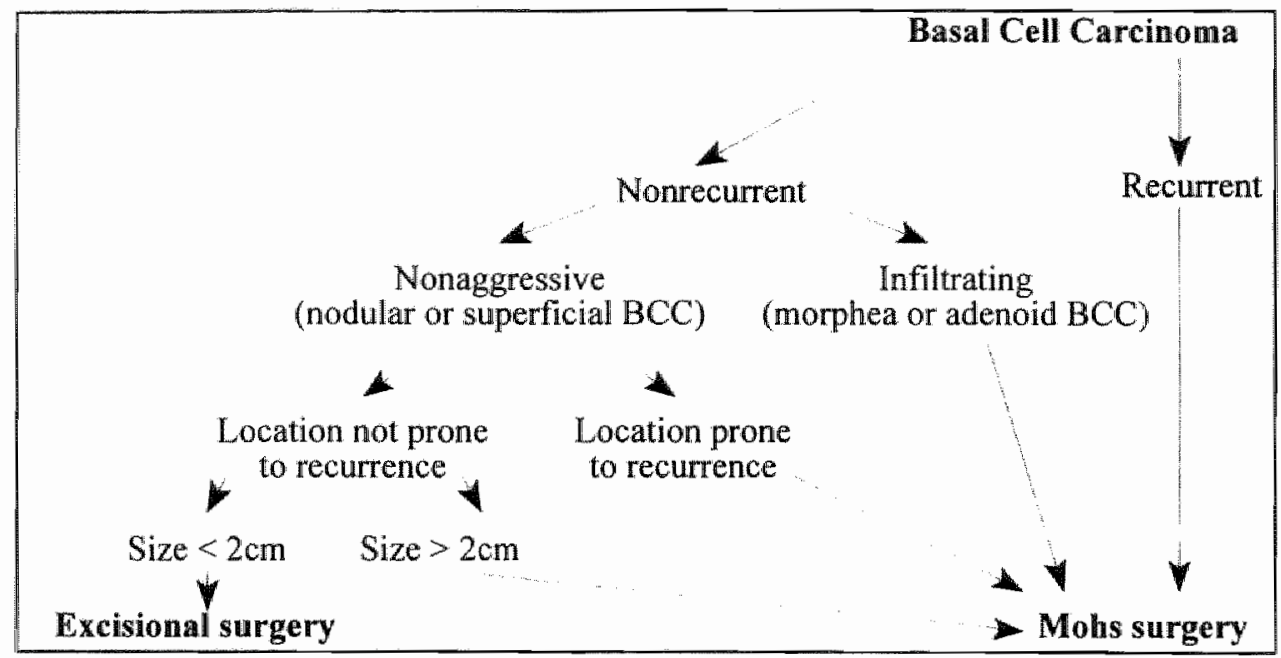

Fig 1 . Algorithm for treatment of $\mathrm{BCC}^{\mathrm{i}}$

3.3. Mohs' Micrographic Surgery step by step (based on the description by Mohs $^{14}$ and Snow ${ }^{15}$ and our own experience):

1) Positioning: To ensure correct positioning during the operation, a line is drawn from $A$ to $B$ through the centre of the tumor. A perpendicular line is drawn from $C$ to $D$. We use a copy of a map (see fig. 2.) to document the anatomical location of each specimen. Although minor differences in practice exist, ${ }^{16}$ the procedure begins with the assessment and marking of the clinical borders of the tumor (although many tumors treated by MMS have poorly defined clinical margins).

2) Anesthetic: Local anesthetic is then injected by local infiltration, field blocks, and/or regional nerve blocks. Lidocaine $1 \%$ with epinephrine 1:100,000 is generally used with a long-lasting local anesthetic such as $0,5 \%$ bupivacaine.

3) Tumor debulking: The bulk of the tumor is removed by scalpel (especially fibrotic and umors recurrent in scars) or curet (especially primary and nodulocystic lesions). This gives a first impression of the extent of the tumor; it may also reduce the number of layers needed to be excised to reach tumor-free tissue. (Fig. 3A).

4) First Mohs 'cut: The lirst micrographic specimen is obtained by excision of a small layer in a saucer-like manner that leaves a border of $2-3 \mathrm{~mm}$ of skin from the edge of the defect created by the curet/scalpel. (Fig. 3B). 
With this and all epidermal incisions are made with the scalpel blade held at around a 45-degree angle. This facilitates the processing of the tissue and the inclusion of all of the epidermal margin in the horizontal Mohs' frozen sections.

On average, a typical Mohs" layer includes 2 to $3 \mathrm{~mm}$ of epidermal skin edge and is approximately 2 to $3 \mathrm{~mm}$ thick. From the Mohs' technician's point of view, if layers are too thin, they often fragment during processing; similarly, layers that are too thick may be difficult to handle, subdivide, and process satisfactorily.

Most Mohs' surgeons remove the layers as a single intact specimen because this minimizes the risk of incorrect orientation. Orientation, which is crucial, is maintained at all stages of the technique. It begins with making score marks on the skin with the scalpel, usually at the top (pointing to the top of the patients head), at the bottom (pointing to the toes), and to each side.

5) Color coding: Once the specimen is removed it is appropriately positioned on an anatomically marked transfer card. (Fig. 3C). The tissue removed, is, when needed, subdivided into pieces small enough to fit on the cryostat object disc and the histology slide. (Fig. 3D). Using a color-coding system, the specimens are marked with colored dyes. (The Davidson Marking System, manufactured and distributed by Bradley Products Inc. PO Box 201405, Bloomington MN 55420, USA). (Fig. 3E).

The colored margins can easily be identified in the frozen sections. and this enables the surgeon to position the excised tissue accurately. Chromacoding tissue also permits the micrographic surgeon to asses the completeness of the Mohs' sections.

Standard nomenclature allows the use of dyes on the tissue to be recorded on the Mohs" map as a series of dots, dashes, crosses, etc.

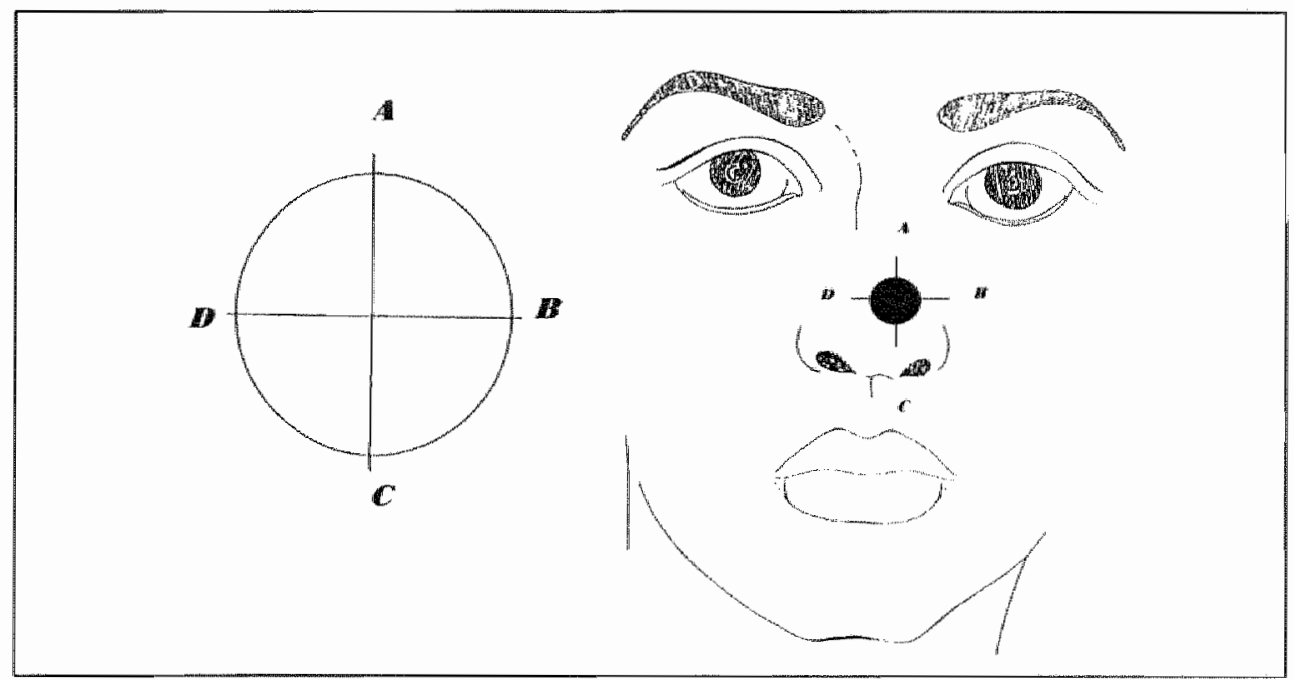

Fig 2. Example of the Mohs'-map for a tumor located on the nose.

To ensure correct positioning during the operation, a line is drawn from A to B through the centre of the tumor. $A$ perpendicular line is drawn from $C$ to $D$. The tumor will be devided into 4 pieces, Each individual piece will be colored, using the color-coding system. Then frozen sections will be cut from the underside of each piece. 

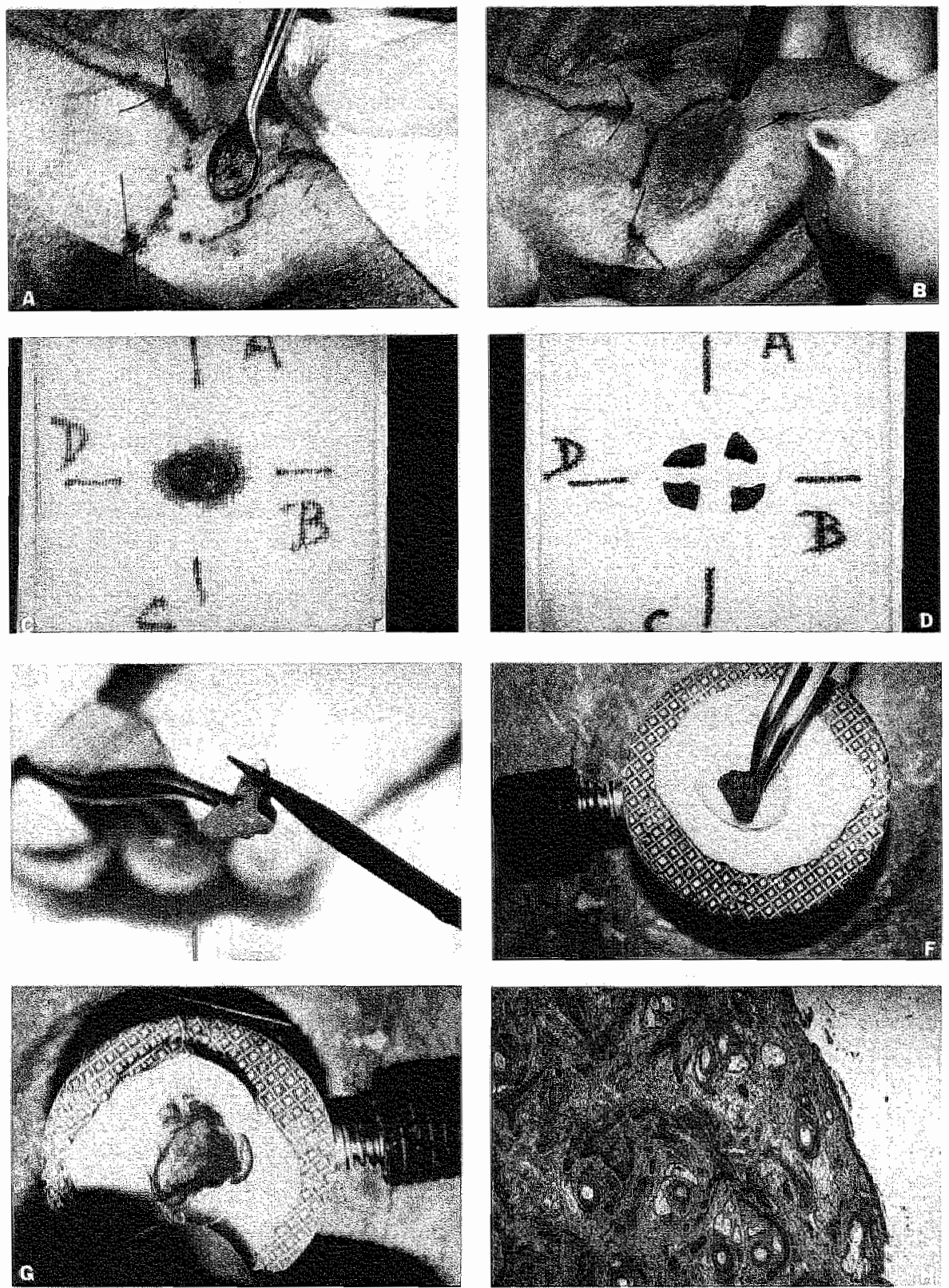

Fig 3: Fig 3A: The bulk of the tumor is removed by scalpel or curettage, fig 3B: Excision of a smail layer in a saucer-like manner that leaves a border of $2-3 \mathrm{~mm}$ of skin from the edge of the defect created by the curette/scalpel. fig 3C: The specimen is removed and appropriately positioned on an anatomically marked transter card, fig 3D: The tissue is subdivided into pieces small enough to fit on the cryostat object disc, fig $3 \mathrm{E}$ : The specimens are matked with colored dyes, fig 3F: A piece is placed on the cryostat, fig 3G: The lateral and deep margins of the piece are flattened, fig $3 \mathrm{H}$ : Frozen sections are cut horizontally from the underside of the tissue specimen, and are then transferred to glass microscope slides. and stained with hematoxylin and eosin. The $\mathrm{BCC}$ can be recognised easily. 
6) Mapping: A map of the umor site, including a diagram of all excised tissue specimens and appropriate tissue color codes, is prepared before histologic processing. (Fig. 2).

7) Horizontal cuts: Using small pieces on the cryostat it is possible to fatten the laterial and deep margins of the tissue, so an essential part of Mohs surgery can be performed: the frozen sections are cut horizontally from the underside of the tissue specimen. Initial sections are ignored until the technician is satisfied that all the surgical margins are present so the Mohs' surgeon and/or pathologist will be able to examine the entire deep and lateral margins of the Mohs' layer. This method allows microscopic examination of the entire deep and peripheral margins of the excised area. (Fig. $3 F^{*}$, $3 \mathrm{G}, 3 \mathrm{H}$ ). The sections are then transferred to glass microscope slides, labeled, and stained with hematoxylin and eosin. (The color-coding dyes are easy to recognize).

8) Microscopy: The surgeon evaluates each section and correlates the color dyes with the "in vivo" location. When residual tumor is identified histologically, the systems of dyes, score marks, and accurate mapping allows the position of recidual numor to be accurately marked on the Mohs map. This previously drawn map is marked to indicate the precise areas containing residual tumor (deep margin or epidermal spreading).

The patient can then be taken back to the procedure room. If necessary, anesthesia is reinforced and another layer is excised precisely at the tumor site. Removing of surrounding healthy tissues is minimised. The entire Mohs' cycle is then repeated untill all margins are tumor free.

9) Reconstruction and postoperative care: Once the tumor is resected, the resulting defect is evaluated to consider whether immediate repair should be done or whether the wound should be allowed to heal naturally. One advantage of Mohs' surgery is that, with certain exceptions, defects may be reconstructed immediately after the achievement of tumor-free margins. ${ }^{17}$ This reconstruction can be done by the Mohs" surgeon, or in collaboration with other specialists. For example: collaboration with oculoplastic colleagues offers patients optimal treatment of NMSC of the eyelid and inner canthal area.

\subsection{Mohs versus other treatments}

The Mohs method couples precise and complete tumor removal with preservation of most normal surrounding tissue. The cure rate by MMS is greater than $98 \%$ for previously untreated non-melanoma tumors of all types and better than $93 \%$ for recurrent tumors. ${ }^{18}$ In managing the patient with a $\mathrm{BCC}$, four goals should be kept in mind: 1) total removal or destruction of the $B C C, 2)$ preservation of normal tissue; 3) preservation of function: 4 ) optimal cosmetic result.

There is a big difference between the horizontal cuts used in MMS and the conventional method of processing tissue by vertical bread-loaf cuts. The Mohs method permits examination of all the surgical margins in question.

Up to $100 \%$ of tumor margins are microscopically examined in MMS; this contrasts with $0.01 \%$ of tumors treated using standard excisionals and histologic methods. ${ }^{19} \mathrm{By}$ 
excising the tissue layer by layer and by examining the entire deep surface of each layer under the microscope, the tumor can be followed until nomal isswe occurs.

Recently by using modem molecular-analysis-methods, an PCR assay based on p53 gene mutation) MMS has been validated: negative margins by the histological technique were also negative by molecular examination.

Nowadays MMS should be considered whenever maximal cure rates are needed, especially when this is coupled with a desire to preserve as much nomal tissue as possible. Consequently, the technique is most often used on the face, where most skin cancers arise. Many ophthalmologists recognize MMS as the treatment of choice for periocular BCC, and some consider its use mandatory for all recurrent umors, regardless of size." It has been shown that more aggressive subtypes of $\mathrm{BCC}$ (infiltrative, morpheaform, micronodular, and mixed) require more MMS stages to achieve tumor-free margins, which is consistent with the concept that these subtypes usually require more aggressive treatment at the start. ${ }^{22}$

In a first prospective randomised study, ${ }^{23}$ comparing surgery (with frozen sections) and radiotherapy, for previously untreated $\mathrm{BCC}$, surgery was shown to be superior to radiotherapy in treatment efficacy and cosmetic result. For untreated $\mathrm{BCC}$ of the face of less than $4 \mathrm{~cm}$, surgery is recommended as first-line treatment. In general, MMS is considered an expensive treatment modality, however when compared to radiotherapy, MMS is relatively inexpensive.

The main indications for MMS are listed in Table 1.

Table 1

Indications for MMS in the management of $\mathrm{BCC}$

Tumors in anatomic areas associated with a high risk of recurrence (mainly head and neck), especially around the eyes, lips and ears

Recurrent tumors

Large or deeply penetrating tumors

Morpheic (sclerasing) type

Metatypical (basosquamous) type

Perineural $\mathrm{BCC}$

Incompletely excised tumors

Tumors in areas where maximal tissue preservation combined with maximal cure rate is essential (e.g. eyelid)

Facial BCC in patients with Nevoid BCC Syndrome.

Tumors arising in areas previously trented with X-ray therapy (e.g., for acne or vascular malformations) Tumors in young patients

In the young patient, one may wish to provide the patient with the highest likelihood of cure. This is particularly true when tumors occur in females on cosmetically obvious anatomic locations. Under such circumstances, other forms of treatment may be less aggressive than necessary. It has been shown that aggressive-growth $B C C$ is more frequently noted in patients under 35 years of age than in those older. ${ }^{24}$

In the mean time it is important to note that MMS is applicable to selected cases only. Most NMSC can be treated by other, readily available and cheaper modalities with 
similarly high cure rates. This is particularly true of most lesions on the trunk and limbs and also for small, well-defined lesions on the face. If a lesion meets one or more of the criteria listed in Table 1, however, serious consideration should be given to the use of MMS.

The published 5-year cure rates of MMS for primary BCC is over $98 \%$ (Table 2).

Table 2

Recurrence rates for Mohs' Micrographic Surgery of primary and recurrent BCC

\begin{tabular}{lrc}
\hline Study & No. of Patients & 5-year Recurrence Rate $\%$ ) \\
\hline Mohs ${ }^{25}$ (primary) & 6187 & 0,7 \\
Robins $^{26}$ (primary) & 1483 & 1.8 \\
Roenigk $^{27}$ (primary) & 367 & 1,4 \\
Rowe $^{26}$ (recurrent) & 3009 & 5,6 \\
\hline
\end{tabular}

\subsection{Treatment of recurrent $\mathrm{BCC}$}

With a 5-year cure rate for recurrent $\mathrm{BCC}$ of $94 \%$, MMS is the treatment of choice for recurrent $\mathrm{BCC}{ }^{28}$ Recurrent $\mathrm{BCC}$ of the nodular type, when first excised, may show features of morphea type at the deep invasive margin. ${ }^{29}$ In particular recurrent $\mathrm{BCC}$ may extend several centimetres beyond the apparent clinical borders. In recurrent tumors, scar tissue from previous procedures entraps malignant cells and may act as a barrier to the upward migration of the cells. The BCC then grows at the depth of the initial wound and migrates horizontally far beyond the borders of the old scar. Removal of all the scar tissue from previous treatments and examination of all excised tissue with frozen sections is necessary to assure complete removal of the tumor. Often, normal anatomy becomes distorted. It becomes difficult to easily find vital structures such as branches of the facial nerve within this setting. The overall 5-year recurrence rate of primary BCCs treated with curettage-electrodesiccation, $X$-ray or surgical excision is $15 \%$ (Dubin 1983). The 5-year recurrence rate for standard surgical excision of recurrent BCCs are given in Table 3.

Table 3

Recurrence rates for Standard Surgical excision of recurrent BCC

\begin{tabular}{lcc}
\hline Stucly & No. of Patients & 5-year Recurrence Rate $(\%)$ \\
\hline Dubin $^{36}$ & 36 & 19,4 \\
Hayes $^{31}$ & 202 & 17,2 \\
Rank $^{33}$ & 183 & 20,2 \\
Taylor $^{33}$ & 282 & $11^{\circ}$ \\
\hline
\end{tabular}

* 2-year Recurrence Rate 
The advantages and disadvantages of MMS are given in tables 4 and 5 .

Table 4

Advantages of Mohs Micrographic Surgery

Precise control of tumor margins;

Conservation of the maximum amount of healthy ussue

Berter than $98 \%$ cure rate for tumors not reated previously ${ }^{34}$.

Beter than 930 cure rate for recurent tumors;

(Cosituffecuve outpatient surgery).

\section{Table 5}

Disadwantages of Mohs' Micrographic Surgery

Tine-consuming procedure and labor intersive.

More expensive than traditional outpatient surgery because of the need for special laboratory processing and microscopic examination using a high quality binocular microscope;

There are only few qualfied Mohs-surgeons in the Netherlands (physicians need training in skin surgery, pathology and oncology).

The most commonly accepted indications for MMS are recurrent $\mathrm{BCC}$ and $\mathrm{SCC}$, but MMS has proven its utility in a wide array of skin neoplasms (Table 6).

Table 6

Indications for Mohs Micrographic Surgery

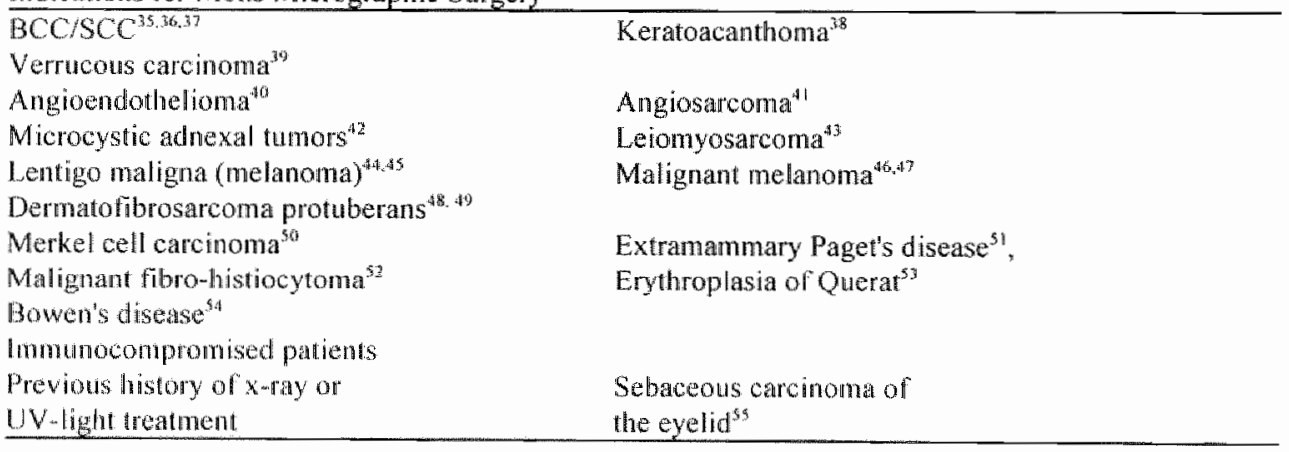


We will report the first results of Mohs' Micrographic Surgery for BCC in the Netherlands:

Patients and Methods: 208 extensive BCC in 198 patients were treated with MMS, with a mean follow up period of 6.4 years.

Patients: 198 patients; 115 male 83 female; age: $38-91$ yrs, mean 62.5 yrs. Location of the BCC: headineck area: 182 ( 80 on the nose: 18 periocular; 14 upper lip, 37 cheek; 33 other) chest: 12 , back: 8 , arm: 3 , perianal: 2 , vulva: 1 . Of the total number of 208 $\mathrm{BCC}, 59$ were primary $\mathrm{BCC}$ and 149 were recurrent $\mathrm{BCC}$. The size of the primary $\mathrm{BCC}$ ranged from 0.8 to $2.5 \mathrm{~cm}$. The recurrent ranged from 0.9 to $21 \mathrm{~cm}$. 119 of the $208 \mathrm{BCC}$ were $>2 \mathrm{~cm}$ and 115 of the 198 patients had a history of multiple $\mathrm{BCC}$. The histologic subtypes were morpheaform (179) and nodular (29). The previous treatment for these $\mathrm{BCC}$ were: cryosurgery, excision and radiotherapy. $46 \mathrm{BCC}$ were postradiation recurrences. Most of the operations (163) were done under general anesthesia, either because of the extent or location of the BCC.

Results: $208 \mathrm{BCC}$ were treated with MMS with a mean follow-up period of $6.4 \mathrm{yrs}$. $\mathrm{BCC}$ recurrences occurred in 4 patients: a woman with a long history of unsuccesful treatment with radiotherapy, surgery and cryosurgery for a $\mathrm{BCC}$ above the right eye had a recurrence after $1.5 \mathrm{yrs}$. She was retreated with MMS, but had a second recurrence after 1 year. One man with recurrent paranasal $\mathrm{BCC}$ had a recurrence after 3.5 yrs. He had a second MMS operation and so far, has had no recurrence. One man of $68 \mathrm{yrs}$ had a recurrence after 18 months of a paranasal BCC and was succesfully retreated with MMS. A 64 yr old man had over $25 \mathrm{BCC}$ which have been treated over a 12 year period. A $2.5 \mathrm{~cm} \mathrm{BCC}$ of the left side of the face was treated by MMS, and a $1.5 \mathrm{~cm} \mathrm{BCC}$ of the nose. After $5 \mathrm{yrs}$ the $\mathrm{BCC}$ of the face recurred and was retreated with MMS. Two operations could not be finished by MMS, because of intra-orbital and intra-ocular involvement. Four recurrences of $208 \mathrm{BCC}$ treated with MMS gave a $2 \%$ recurrence-rate of severe and extensive tumors for a mean follow-up time of 6.4 yrs. See Fig $4 a-4 d$ for an example of a patient with BCC treated with MMS.

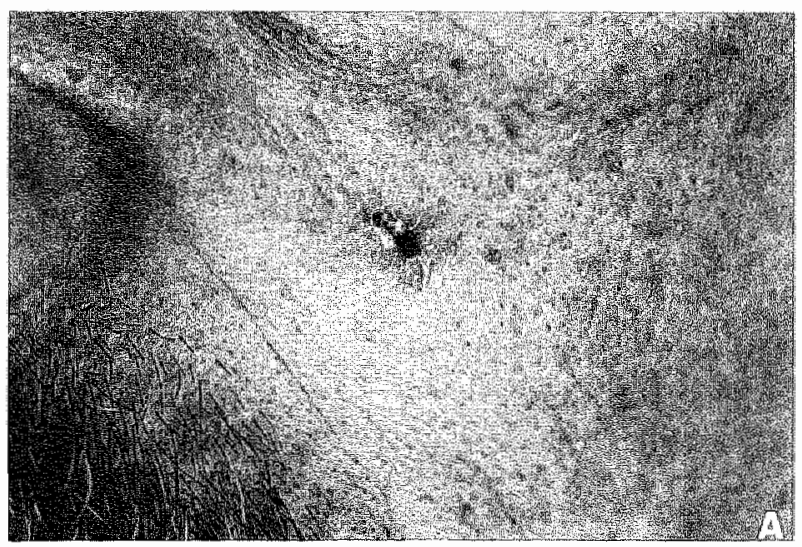

Fig 4a, morheic BCC on the right cheel 

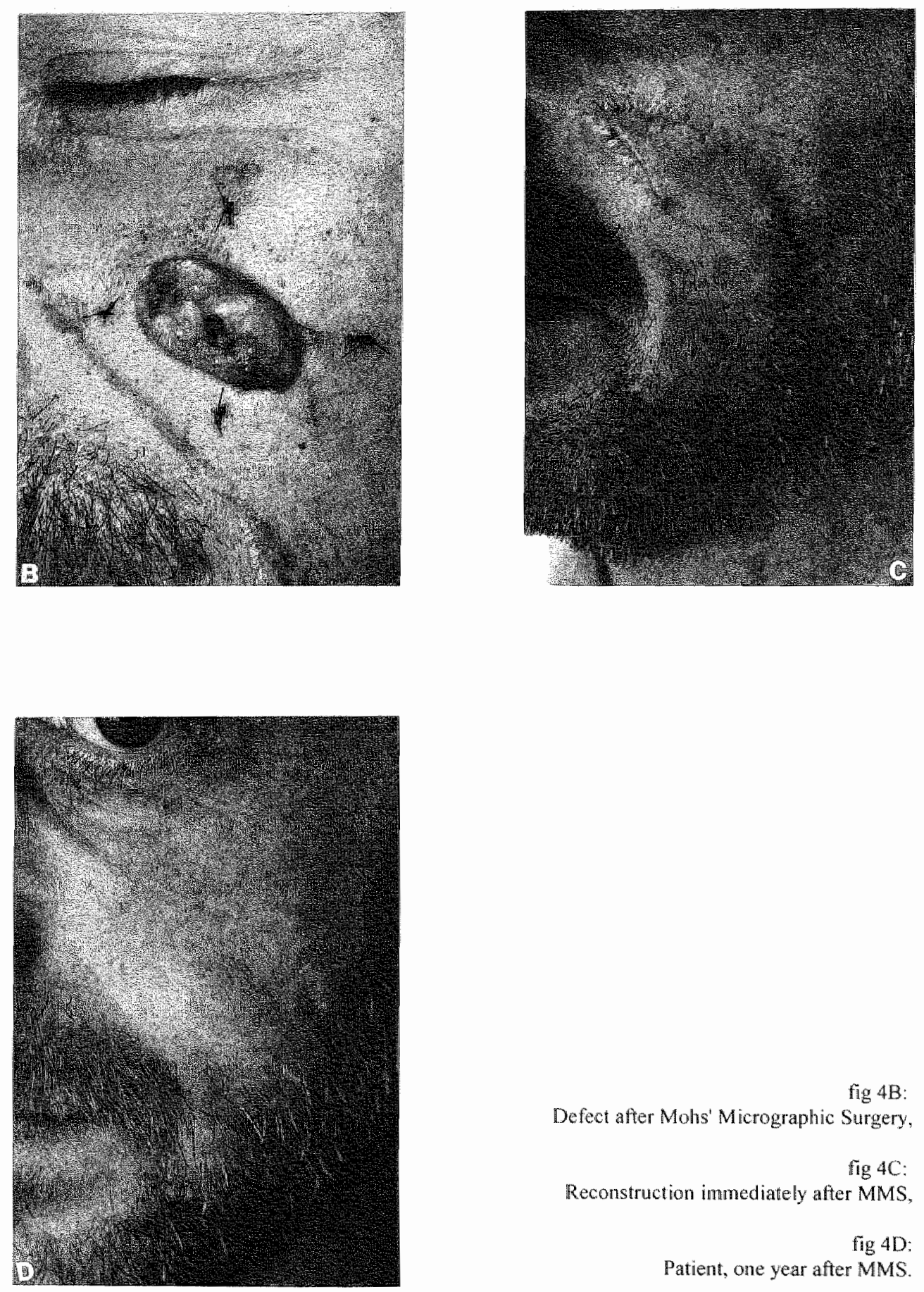

fig $4 \mathrm{~B}$ :

Defect after Mols' Micrographic Surgery,

fig 4C:

Reconstruction inmediately after MMS,

fig $4 \mathrm{D}:$

Patient, one year after MMS. 


\subsection{Discussion}

Bearing in mind processing difficulties or errors in interpreting the microscopic sections, MMS provides the best prospect of total tumor removal ${ }^{56}$ and relates to preservation of function and cosmesis. The greatest value and practice lies in the treatment of advanced $\mathrm{BCC}$ of the face. There are now short-cuts with the Mohs method. A "pseudo-Mohs" method with vertical sections does not permit examination of all margins and introduces the possibility of sampling error. ${ }^{5 ?}$

To further investigate the indications of MMS randomised studies are necessary.

Possible explanations for $\mathrm{BCC}$ recurrence after MMS are:

- inadequate techniques by the surgeon, or histopathologic analyst;

- multifocal growth of BCCs;

- submicrographic spreading of the tumors (e.g. perineural spreading of the tumor).

It is important to state that we are not recommending MMS as an exclusionary procedure. Clearly, there is more than one way to treat a patient with skin cancer. To emphasize this concept, we have made an effort to clarify the indications and applications for MMS. Remains the question: How many NMSC require MMS?

Based on studies in the US: over $30 \%$ of NMSC. ${ }^{58}$ For the Netherlands: more than 10.000 NMSC annually!

Finally we would like to discuss the advantages of a multidisciplinary approach to managing patients with cutaneous neoplasms. Many Mohs' surgeons are qualified to reconstruct postoperative wounds. However, in many cases, we work in conjunction with subspecialists from several disciplines. With the increase in the incidence of skin cancer, we suggest that there will continue to be a need for qualified cutaneous oncologists, irrespective of their subspecialty. By interspecialty contact between dermatologists, Mohs' surgeons, surgical oncologist, plastic surgeons, otorhinolaryngologic surgeons, ophthalmic (plastic) surgeons, radiation oncologists, medical oncologists and psychologists, patients will continue to benefit from obtaining optimal medical care with regard to their cutaneous neoplasm.

\subsection{Certification in Mohs" surgery}

Physicians with appropriate training as defined by the American College of Mohs' Micrographic Surgery and Cutaneous Oncology are qualified to perform Mohs' surgery. These persons are currently required to complete a number of 100 Mohs procedures, supervised by a fully trained Mohs' surgeon.

The fully trained Mohs' surgeon is skilled in surgical procedures involving skin tumors and reconstruction of surgical defects. He or she also needs to be fully trained in histopathologicic techniques and interpreting tangentially cut sections. A Mohs' surgeon not only needs to know how to deal with small recurrent tumors, but also with larger tumors involving vital structures. 


\section{References}

1. Mohs FE. Chemosurgery. A microscopically controlled method of cancer excision. Arch Surg $1941: 42: 279,95$.

2. Mohs FE, Lathrop TG. Modes of spread of cancer of skin. Arch Dermatol 1952:66:427-39.

3. Tromovitch TA, Stegeman SJ. Microscopically controlled excision of skin tumors. Arch Dermatol $1974 ; 110: 231-2$

4. Braun $M$. The case for Mohs surgery by the fixed-tissue technique. I Dermatol Surg Oncol $1981,7,634440$.

5. Urbach F. Geographic distribution of skin cancer. J Dermatol Surg Oncol 1971;3:219-34.

6. Coebergh IWW, Neumann HAM, Vrints LW, et al. Trends in the incidence of non-melanoma skin cancer in the Netherlands 1975 1988: a registry-based study. $\mathrm{Br} \mathrm{J}$ Dermatol 1991;125:3539.

7. Wallenberg P, Skog E. The incidence of basal cell carcinoma in an area of Stockholm County during the period 1971-1980. Acta Dermatol. Venereol., 1991;71:134-7.

8. Gloster HM, Brodland DG. The epidemiology of skin cancer. Dematol Surg 1996:22:217-26.

9. Thissen MR. Neumann HA. Berretty PJ, Ideler AH. De behandeling van patienten met basalecelcarcinomen door dermatologen in Nederland. NTVG 1998;142:1563-7.

10. Scoto J, Fears TR, Fraumeni JF Jr. Incidence of nonmelanoma skin cancer in the United States. Washington, DC: Government Printing Officie, 1983. (NIH publication no, 83-2433).

11. Mikhail GR, Nims LP, Kelly AP Jr, et al. Metastatic basal cell carcinoma. Review, pathogenesis and report of two cases. Arch Dermatol 1977:113:1261-9.

12. Mohs FE. Modes of spread of cancer. In Chemosurgery: Microscopically controlled surgery for skin cancer. Springfield, IL., Charles C Thomas 1978, p 256.

13. Bennett RG; Skin cancer. In Rakel RE: Conn's Current Therapy. Philadelphia W.B. Saunders Co., 1986.

14. Mohs $\mathbb{F}$. Origin and progress of Mohs micrographic surgery. In: Mikhail G, ed. Mohs micrographic surgery. Philadelphia: Saunders, 1991:1-10.

15. Snow SN. Technicues and indications for Mohs micrographic surgery. In: Mikhail G, ed. Mohs micrographic surgery. Philadelphia: Saunders, 1991:11-60.

16. Miller LJ, Argenyi ZB, Whitaker DC. The preparation of frozen sections for micrographic surgery: a review of current methodology. J Dermatol Surg Oncol 1993:19:1023-9.

17. Rudolph R, Miller SH. Reconstruction after Mohs cancer excision. Clin Plast Surg 1993;20:15765.

18. Rowe DE, Carroll RJ, Day CL. Jr. Prognostic factors for local recurrence, metastasis, and survival rates in squamous cell carcinoma of the skin, ear amd lip: implications for treatment modality sellection. I Am Acad Dermatol 1992:26:976.90.

19. Abide JM. Nahai F, Bennet RG. The meaning of surgical margins. Plast Reconstr Strg $1984: 73: 492 \cdot 6$.

20. Rosin MP. Miller SJ, Schwab D, et al. Molecular analysis of effectiveness of Molns surgical technique. Lancet 1996:347:1692-3.

21. Leshin B, Yeatts P. Auscher M, et al. Management of periocular basal cell carcinoma: Mohs' micrographic surgery versus radiotherapy. Surv Ophthalmol 1993;38:193-212.

22. Orengo IF, Salasche SJ, Fewkes J, et al. Correlation of histologic subtypes of primary basal cell carcinoma and number of Mohs stages required to achieve a tumor-fiee plane. I Am Acad Dermatol 1997;37:395-7.

23. Awril M-F, Auperin A, Margulis A, et al Basal cell carcinoma of the face: surgery or radiotherapy? Results of a randomised study. Br J Cancer 1997:76:100-6. 
24. Leffell DJ, Headington IT, Wong DS, Swanson NA. Aggressive-growth basal cell carinoma in young adults. Arch Dermatol 199:1:127:1663-7.

25. Mohs FE. Chemosurgery: Microscopically controlled surgery for skin cancer Springfield. IL: Charles C. Thomas 1978, pp 59, 158.

26. Robins P. Chemosurgery: My 15 years of experience. J Dermatol Surg Oncol 1981:7:779-89.

27. Roenigk $R$, Ratz $\rrbracket$, Bailin $P$, Wheeland $R$. Trends in the presentation and treatment of basal cell carcinomas. J Dermatol Surg Oncol 1986:8:860-5.

28. Rowe DE, Carroll RJ, Day CL. Mols surgery is the treatment of choice for recurrent (previously treated) basal cell carcinoma. J Dermatol Surg Oncol 1989;15:424-31

29. Robinson JK. Expression of keratin proteins in deeply invasive basal and squamous cell carcinoma: An inmunohistochemical study. J Dermatol Surg Oncol $\rrbracket 987 ; 13 ; 283-94$.

30. Dubin N, Kopf A. Multivariate risk score for recurrence of cutaneous basal cell carcinomas. Arch Dermatol 1983;119:373-7.

31. Hayes H. Basal cell carcinoma: The East Grinstead experience. Plast Reconstr Surg 1962:30:273-80.

32. Rank B, Wakefield A. Surgery of basal cell carcinoma. Br J Surg 1958:45:53 1-47.

33. Taylor GA, Barisoni D. Ten Years' experience in the surgical treatment of basal cell carcinoma: A study of factors associated with recurrence. Br I Surg 1973:60:522-5.

34. Rowe DE, Carrol RJ, Day CL Jr. Long-term recurrence rates in previously untreated (primary) basal cell carcinoma: implications for patients follow-up. J Dermatol Surg Oncol 1989:15:31528.

35. Barrett TL, Greenway HT, Massullo V, Carlson $C$. Treatment of basal cell carcinoma and squamous cell carcinoma with perineural invasion. Adv Dermitatol 1993;8:277-304.

36. Kirsner $\mathbb{R S}$, Spencer J, Falanga $V$, et al. Squamous cell carcinoma arising in osteomyelitis and chronic wounds. Treatment with Mohs micrographic surgery vs amputation. Dermatol Surg 1996;22:1015-8.

37. de Berker DA, Dahl MG, Malcolm AJ, Lawrence CM. Micrographic surgery for subungual squarnous cell carcinoma. $\mathrm{Br} J \mathrm{Pl}$ |ast Surg 1996:49:414-9.

38. Larson PO. Keratoacanthomas treated with Mols' micrographic surgery (chemosurgery). A review of forty-three cases. J Am Acad Dermatol 1987;16:1040-4.

39. Swanson NA, Taylor WB. Plantar verrucous carcisoma. Literature review and treatment by the Mohs' chemosurgery technique. Arch Dermatol 1980;116:794-7.

40. Mikhail GR, Kelly AP Jr. Malignant angioendothelioma of the face. J Dermatol Surg Oncol 1977:3:181-3.

41. Goldberg DJ, Kim YA. Angiosarcomat of the scalp theated with Mohs micrographic surgery. I Dermatol Surg Oncol 1993;19:156-8.

42. Burns MK, Chen SO, Goldberg LH. Microcystic adnexal carcinoma. Ten calses treated by Mohs Micrographic Surgery. J Dermatol Surg Oncol 1994;20:429-34.

43. Davidson LL, Frost ML, Hanke CW, Epinette WW. Primary leiomyosarcoma of the skin. Case report and review of the literature. J Am Acad Dermatol 1989,21:1156-60.

44. Cohen LM. McCall MW. Hodge SJ, et al. Succesful treatment of lentigo maligna and lentigo maligna melanoma with Mohs' micrographic surgery aided by rush permanent sections Cancer $1994 ; 73: 2964-70$.

45. Gaspar ZS, Dawber RP. Treatment of lentigo malligna. Australias J Dermatol 1997;38:1-6.

46. Kaspar TA, Wagmer RF Jr. Mohs Micrographic sturgery for thin stage I malignant melanoma: rationale for a modern management strategy. Cut's 1992:50:350-1.

47. Brooks NA. Fixed-tissue micrographic surgery in the treatment of cutaneous melanoma. An overlooked cancer treatment strategy. I Dermatol Surg Oncol 1992;18:999-1000. 
48. Jiminez F. Grichnik IM, Buchanan MD, Clark RE. Immunohistochemical margin control applied to Mohs micrographic surgery excision of dermatofibrosarcoma protuberans. J Dermatol Surg Oncol 1994:20:687-9.

49. King $M$, Ocheltree I. Dermatofibrosarcoma protuberans treatment and reconstruction: a case study. Plast Surg Nurs 1996;16:77-82.

50. Roenigk RK. Goltz RW. Merkel cell carcinoma - a problem with microscopically controlled surgery. J Dematol Surg Oncol 1986;12:332-6.

51. Harris DW, Kist DA, Bloom K, Zachary CB. Rapid staining with carcinoembryonic antigen aids limited excision of extramammary Paget's disease treated by Mohs surgery. I Dermatol Surg Oncol 1994:20:260-4.

52. Brown MD, Swanson NA. Treatment of malignant fibrous histiocytoma and atypical fibrous Kantomas with micrographic surgery. J Dermatol Surg Oncol 1989:15:1287-92.

53. Bernstein Gi, Forgaard DM, Miller JE. Carcinoma in situ of the glans penis and distal urethra. J Dematol Surg Oncol 1986;12:450-5.

54. Moriz DL. Lynch WS. Extensive Bowen's disease of the penile shaft treated with fresh tissue Mohs micrographic surgery in two separate operations. J Dermatol Surg Oncol 1991;17:374-8.

55. Dzubow LM. Sebaceous carcinoma of the eyelid: treatment with Mohs surgery. J Dermatol Surg Oncol $1985 ; 11: 40-4$.

56. NeIson BR, Railan D, Cohen S. Mohs" Micrographic Surgery for nonmelanoma skin cancers. Clin Plast Surg 1997;24:705-18.

57. Dzubow LM. Mohs surgery. Lancet 1994;19:433-4.

58. Welch ML, Anderson LL, Grabski WJ. How many nonmelanoma skin cancers require Mohs micrographic surgery. Dermatol Surg $1996 ; 22: 711-3$. 


\section{Chapter 4}

\section{Keratins (K8 and K19) as potential markers of recurrent basal cell carcinoma}

Gertruud A.M. Krekels, Marc E.J.M. Verhaegh, Sjoerd Sc. Wagenaar, Frans C.S. Ramaekers, H.A.Martino Neumann.

Eur I Dermatol 1997;7:158-60.

Yearbook of Dermatologic Surgery 1998. Mosby, New York. 


\section{Introduction}

The incidence of basal cell carcinoma (BCC), the most common malignancy in Caucasians, is rapidly increasing worldwide. ${ }^{1,2}$ In many cases of $\mathrm{BCC}$ a single treatment is sufficient, but extensive treatment is necessary in others. The latter include recurrent cases of BCC, for which Mohs' Micrographic Surgery is often the treatment of choice. ${ }^{3.4}$ Based on morphological or histological criteria or localization of the tumor it can often not be predicted which $\mathrm{BCC}$ will have a recurrent nature. Recurrent $\mathrm{BCC}$ may be very aggressive and have histologic features not seen in the original neoplasm. Recurrent BCC of the nodular type, when first excised, may show features of morphea type at the deep invasive margin. ${ }^{5}$ Intermediate filament proteins are important constituents of the cytoskeleton. They seem to be involved in providing internal stability within the cell, transport functions and gene regulation. Although the original class of intermediate filaments is usually conserved in tissues after neoplastic transformation, epithelia show a tendency to shift their pattern of keratin expression in a manner which, while not predictable with precision, may sometimes be of diagnostic or prognostic significance. ${ }^{6.78}$ In order to detect potential differences in the biological behavior between primary (untreated) and recurrent $\mathrm{BCC}$, we have applied a panel of specific monoclonal keratin antibodies to BCC with similar localization but different behavior.

\section{Methods}

\section{Tissue samples}

Ten Caucasian patients ( 7 male and 3 female; age 52-84) with recurrent $\mathrm{BCC}$ were treated by Mohs' Micrographic Surgery (MMS). The number of recurrence ranged from 2 to 7 times. Previous treatment included: cryotherapy, surgical therapy and radiotherapy. Histological classification (nodulocystic $=3$, morphoeic $=7$ ). Fresh tumor material was snap-frozen in the cryostat at $-30^{\circ} \mathrm{C}$ according to the MMS procedure. Specimens were then stored at $-70^{\circ} \mathrm{C}$. Fig. I shows an example of an extensive recurrent $\mathrm{BCC}$, before and after MMS. The control group consisted of 10 Caucasian patients ( 7 male and 3 female; age 59-85) with primary (untreated) nodular BCC. Three-millimetre punch biopsy specimens were taken and snap frozen in liquid nitrogen, and stored at $-70^{\circ} \mathrm{C}$ until use. All BCC were removed from the face.

\section{Immunohistochemistry}

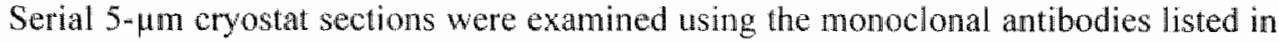
Table 1. The frozen sections were air-dried overnight, fixed with cold methanol $\left(-20^{\circ} \mathrm{C} ; 1 \mathrm{~min}\right)$ and acetone at room temperature for $10 \mathrm{sec}$. Following inhibition of endogenous peroxidase, slides were incubated in normal goat serum (20 min). Subsequent incubation with optimized dilution of the primary antibodies $(60 \mathrm{~min})$ was followed by incubation with peroxidase-conjugated rabbit anti-mouse antibody (Dako A/S Glostrup, Denmark, 1:100 dilution, $60 \mathrm{~min}$ ). 3,3'-diaminobenzidene was used as substrate for the peroxidase ( $8 \mathrm{~min}$ development in darkness). Sections were then 


\section{Results}

The staining results are summarzed in Table 1 and depicted in Fig 2.

Table 1. Monoclonal antibodies ussed in this study Characteristics of kerains, in 10 primary (untreated) and 10 recurrent basal cell carcinoma.

\begin{tabular}{lllrrr}
\hline $\begin{array}{l}\text { Antibody } \\
\text { Recognised }\end{array}$ & Keratin & $\begin{array}{l}\text { Reactivity in } \\
\text { normal epidermis }\end{array}$ & $\begin{array}{l}\text { Primary } \\
\text { BCC }\end{array}$ & $\begin{array}{l}\text { Recurtent } \\
\text { BCC }\end{array}$ & Source \\
RCK 107 & 14 & Basal keratinocytes & $10 / 10$ & $10 / 10$ & 1 \\
LL002 & 14 & Basal + suprabasal keratinocytes & $10 / 10$ & $10 / 10$ & 2 \\
AE 14 & 5 & Basal keratinocytes & $10 / 10$ & $10 / 10$ & 3 \\
RKSE60 & 10 & Suprabasal keratinocytes & $0 / 10$ & $0 / 10$ & 1 \\
E3 & 17 & Outer hair root sheath & $10 / 10$ & $10 / 10$ & 4 \\
RCK 106 & 18 & No staining & $0 / 10$ & $0 / 10$ & 1 \\
RCK 108 & 19 & Outer hair root sheath/sweat duct & $2 / 10$ & $8 / 10$ & 1 \\
M20 & 8 & No staining & $1 / 10$ & $6 / 10$ & 5 \\
\hline
\end{tabular}

Source: 1. Eurodiagnostica; Apeldoorn, the Netherlands, 2. Lab Vision Corporation, USA; 3.T-T. Sun, NY; 4.Troyanovski, Moscow; 5 . Van Muijen, Nijmegen, the Netherlands.

Substantial differences were found between the primary (untreated) and recurrent basal cell carcinomas for keratins 8 and 19.

Briefly, all 20 tumors, comprising 10 severe recurrent $\mathrm{BCC}$ and 10 primary $\mathrm{BCC}$, showed homogeneous staining for the basal cell keratins $\mathrm{K} 5$ and $\mathrm{K} 14$, and for K17. (Fig. 2a and $2 \mathrm{~b}$ ).

Expression of K10, a marker for keratinization, and $\mathrm{K} 18$ one of the simple epithelium markers was not observed in any of the recurrent cases nor in the primary BCC. In eight of the recurrent tumors $\mathrm{K} 19$ was detectable, while only in 2 primary (untreated) $\mathrm{BCC}$. K8 was expressed in 6 recurrent cases, while only in 1 primary tumor. $\mathrm{K} 8$ expression is shown in Fig. $2 \mathrm{c}$ (primary tumor) and $2 \mathrm{~d}$ (recurrent tumor). Co-expression of $\mathrm{K} 8$ and $\mathrm{K} 19$ was found in 5 recurrent basal cell carcinoma.

The combination of these keratins was found in 1 primary (untreated) tumor.

We often noticed the most intense staining reaction in those tumor cells adjacent to the stroma and in the periphery of the tumor nodules, i.e., the invasion front. 


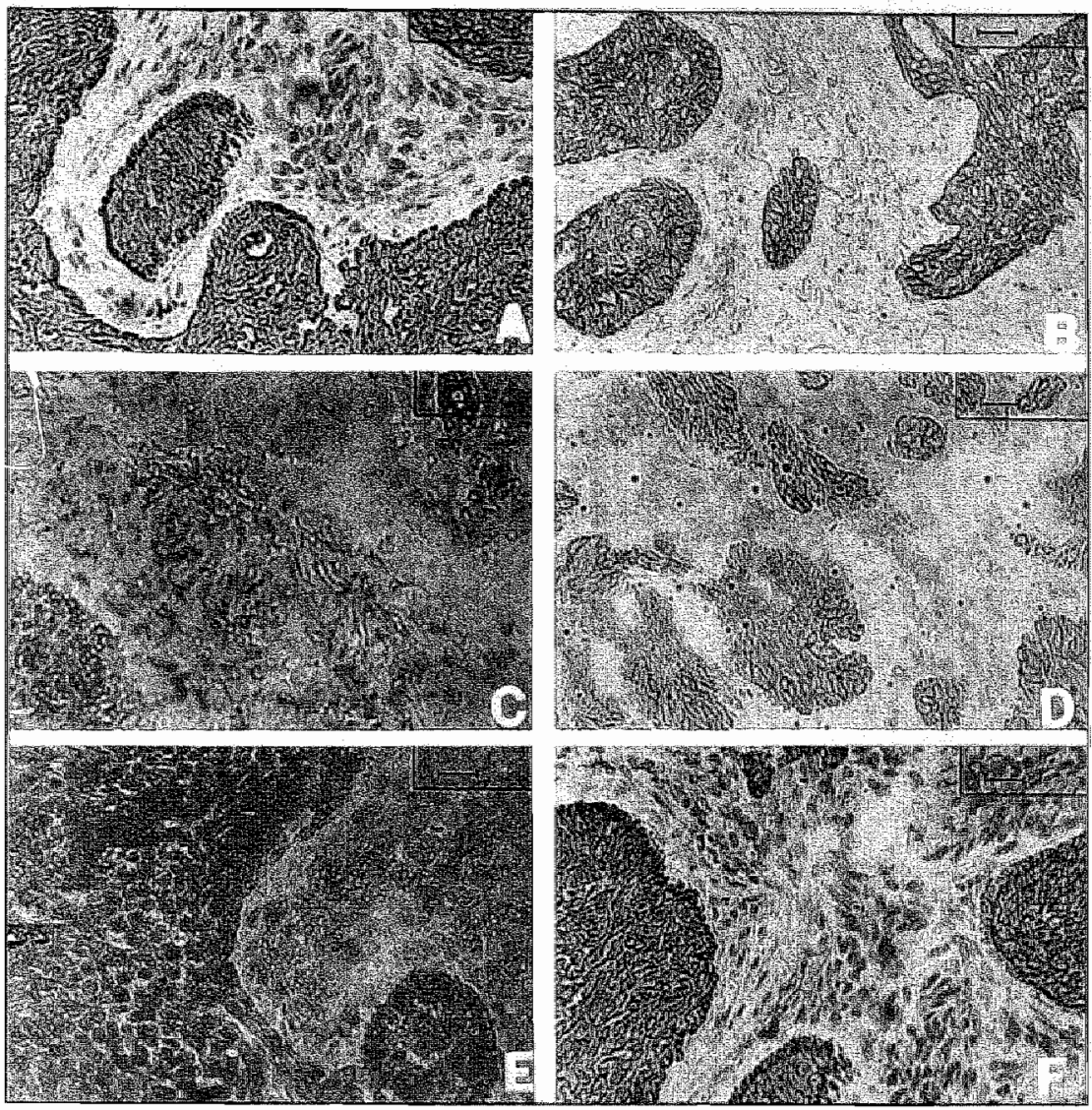

Figure 2

Figure 2. Immunoperoxidase staining pattern of primary $\mathrm{BCC}(\mathrm{a}, \mathrm{c}, \mathrm{e})$ and recurrent $\mathrm{BCC}(\mathrm{b}, \mathrm{d}, \mathrm{f})$

Fig. $2 \mathrm{a}$ and $2 \mathrm{~b}$ E3 (KI7) staining of primary nodular and resp. recurrent (morpheic) BCC.

Fig. $2 \mathrm{c}$ and $2 \mathrm{~d} \mathrm{M} 20$ (K8) staining of primary nodular and resp. recurrent (morpheic) $\mathrm{BCC}$.

Fig. $2 \mathrm{e}$ and $2 \mathrm{f}$ RCK 107 (K 19) staining of primary nodular and resp. recurrent (morpheic) BCC.

In $2 \mathrm{~d}$ and $2 \mathrm{f}$ (keratin 8 and keratin 19 in recurrent $\mathrm{BCC}$ ) positive staining in the periphery of the lumor nests. The primary $\mathrm{BCC}(2 \mathrm{c}$ and $2 \mathrm{e})$ is negative for keratin 8 and 19 . Bar indicates $20 \mathrm{~mm}\left(\mathrm{x}_{200}\right)$. 


\section{Discussion}

Epithelial cells can change their keratin profile during differentiation and tumorigenesis." A number of previous studies of keratin expression in $\mathrm{BCC}$ have been published, ${ }^{19.10 .12}$ but the overall results for the expression of the simple keratins have not been consistent. This may be due to insensitivity of biochemical analyses, differences in the specificity and sensitivity of antibodies used, or to tumor heterogeneity. $K 8$, normally not expressed in the epidermis, has been detected biochemically in some $\mathrm{BCC}$, and was reported to be immunohistochemically detectable. ${ }^{13} \mathrm{~K} 19$ may be observed in epidermal basal cells, in a defined area of the hair follicle and in nipple epidermis. During development of the human epidermis K19 is strongly present in the basilar, and weakly in suprabasilar keratinocytes. ${ }^{14} \mathrm{~K} 8$ and $\mathrm{K} 18$ are the earliest keratins to be expressed in the preimplantation embryo, but are subsequently lost from differentiating tissues. As differentiation of the epidermis begins, expression of K8 and K18 is lost in the skin. We have described a difference between the immunohistochemical staining patterns between primary (untreated) $\mathrm{BCC}$ and recurrent $\mathrm{BCC}$. Recurrent $\mathrm{BCC}$ have an altered keratin profile, displaying an increase in $\mathrm{K} 8$ and $\mathrm{K} 19$ expression. While only a minor fraction of primary (untreated) $\mathrm{BCC}$ express $\mathrm{K} 8$ and/or $\mathrm{K} 19, \mathrm{BCC}$ that have recurred, showed considerable expression of these simple keratins. We often noticed the most intense reaction in tumor cells in close proximity to stroma and in the periphery of the tumor nodules, the area of continuing change and growth, i.e. the invasion front. Similar observations were made in mucosal squamous cell carcinomas and was called the 'interface phenomenon'. ${ }^{15}$ The possible relationship between keratin 8 and keratin 19 expression, and the invasive phenotype of the recurrent BCC cells at the stromal border, lies in an increased flexibility of the cytoplasm of the tumor cells due to a lesser rigidity of its cytoskeletal structure. In this respect keratin 19 is an interesting constituent, since it has been described to occur in certain epidermal basal cells characteristic of regions of labile or variable cellular differentiation. It was therefore designated as a "switch-keratin", allowing the cell to modify its cytoskeletal rigidity. ${ }^{16} \mathrm{~A}$ possible explanation for the significance of simple epithelial keratins may be potential invasion of the dermis.

In other tumors, such as bladder and cervix it was suggested that simple epithelial keratins are elevated with increasing degree of dysplasia. It is also known that during tumor invasion, epidermal basement membranes are lost, hence allowing the surrounding dermal extracelluar matrix to have effects on keratin expression. There have been several studies suggesting that simple epithelial keratins might be associated with malignant transformation. ${ }^{17,18}$

Although we studied only a small number of $\mathrm{BCC}$, our findings demonstrate that in a recurrent basal cell carcinoma, areas of transformed keratinocytes can be found. Apparently, the expression of cytoskeletal components in tumor cells can be influenced by their micro-environment (stroma surrounding the $\mathrm{BCC}$ nests).

Thus, the staining patterns observed in the current study are useful in understanding the nature of the proliferating cells and may help to understand the mechanisms of $\mathrm{BCC}$ carcinogenesis, and may have important diagnostic and prognostic implications. 


\section{References}

1. Coebergh JWW, Neumann HAM, Vrints LW et al. Trends in the incidence of non-melanoma skin cancer in the Netherlands 1975-1988: a registry based study. Br J Dermatol 1991:125:353-9.

2. Wallenberg $\mathrm{P}$, Skog $\mathrm{E}$. The incidence of basal cell carcinoma in an area of Stockholm County during the period 1971-1980. Acta Dermatol venereol 1991:71:134-7.

3. Rowe DE, Carrol RJ, Day Cl. Ir. Mohs surgery is the treatment of choice for recurrent (previously treated) basal cell carcinoma. I Dermatol Surg Oncol 1989:15:424-31.

4. Neumann HAM, Krekels GAM, Verhaegh MEJM. Treatment of 208 extensive basal cell carcinomas with Mohs micrographic surgery. I Eur Ac Derm Venereol 1996;6:217-25.

5. Robinson $\mathrm{JK}$. Expression of keratin proteins in deeply invasive basal and squamous cell carcinoma: An immunohistochemical study. J Dermatol Surg Oncol 1987:13:283-94

6. Broers JLV, Ramaekers FCS, Klein Rot M et al. Cytokeratins in different types of human lung cancer as monitored by chain specific monoclonal antibodies. Cancer Res 1988:48:3221-9.

7. Trask DK, Band V, Zajchowski DA et al. Keratins as markers that distinguish normal and tumor derived mammary epithelial cells. Proc Natl Acad Sci USA 1990;87:2319-23.

8. Schaafsma HE, Ramaekers FCS, Van Mijen GNP et al. Cytokeratin expression patterns in metastatic transitional cell carcinona of the urinary tract, an immunohistochenical study comparing local tumor and autollogous metastase. Am I Pathol 1991:139:1389-1400.

9. Boyd NM, Reade PC. Temporal alterations in cytokeratin expression during experimental oral mucosal carcinogenesis. Carcimogenesis 1991;12:1767-71.

10. Markey AC, Lane EB, MacDonald DM, Leigh IM. Keratin expression in basal cell carcinomas. Br J Dermatol 1992;126:154-60.

11. Habets JMW, Tank B, Vuzewski VD et al. Absence of eytokeratin 8 and inconsistent expression of cytokeratins 7 and 19 in human basal cell carcinoma. Anticancer Res 1988:8:6 1 1-6.

12. Habets JMW, Tank B, Vuzevski et al. Inmunoellectron microscopic studies on cytokeratins in human basal cell carcinoma. Anticancer Res 1989;9:65-70.

13. Lavrijsen APM, Tieben $L M$, Ponec $M$ et al. Expression of EGF receptor, involucrin, and cytokeratins in basal cell carcinomas and squamous cell carcinomas of the skin. Arch Dermatol 1989;281:83-8.

14. Lane EB, Bartek J, Purkis PE, Leigh IM. Keratin antigens in differentiating skin. Ann NY Acad Sci $1985: 445: 241-58$.

15. Schaafsma ME, Van der Velden LA, Manni JJ at al, Inereased expression of cytokeratins 8.18 and vimentin in the invasion front of mucosal squamous cell carcinoma. J Pathol 1993;170: 77-86.

16. Stasiak PC, Purkis PE, Jeigh IM, Lane EB. Keratin 19: Predicted amino acid sequence and broad tissue distribution suggest it evolved from keratinocyte keratins. II Invest Dermatol 1989:92.70716.

17. Kariniemi AL, Virtanen J. Altered keratin expression in benign and malignant skin diseases revealed with monoclonal antibodies. Am J Dermatopathol 19:89:11:202-8.

18. Smedts F, Ramaekers FCS, van Muijen GNP et al. Changing patterns of keratin expression during, progression of cerwical intraepitheliat neoplasia. Am J Pathol 1990;136:657-68. 

Chapter 5

\section{UV carcinogenesis}




\subsection{Introduction}

With regard $10 \mathrm{BCC}$ the literature mentions several points in support of the important causal role of sunlight. (see chapter 2):

1. More than $80 \%$ of BCC occur on the head and neck, the parts of the body which are exposed to sunlight most.

2. Generally speaking, there is a greater incidence of $B C C$ in areas with stronger UV irradiation (the lower geographical latitudes).

3. Caucasians, especially those who sunburn easily, have a greater risk of contracting BCC than people belonging to the pigmented races.

4. Genetic defects characterized by the inability to endure sunlight also lead to a greater chance of contracting BCC (XP, albinism etc), especially at young age. The prevalence of skin cancer on sun-exposed body sites in individuals with XP. suggests that defective repair of UV-induced DNA damage can lead to the induction of skin cancer.' 5. The incidence of BCC is increased for people with outdoor jobs.

6. Migration of fair-skinned racial groups to sunny climates: although sharing the same ancestors, $\mathrm{BCC}$ is far more common among Australian immigrants than among inhabitants of Great Britain/Ireland.

7. Reference in the English literature to "Mariner"s disease or the French literature to 'Cancer des cultivateurs' indicated the occupational hazard for those exposed to the sun.

\subsection{UV Radiation}

Ultraviolet radiation (UVR) is electromagnetic energy emitted by the sun and some artificial sources. It is part of a wide spectrum of radiation, including cosmic rays, gamma rays, $X$-rays, visible light, infrared radiation (heat), microwaves, radar, ctc.

UVR and visible light are medium wavelength radiation (Table 1), which adds sufficient energy to atoms and mollecules to move their outer electrons to higher energy orbitals. The excited electron may then return to the unexcited ground state by losing energy usually as heat, as fuorescence, or by transfer of energy within the molecule or to one nearby. Rarely, but most important, the energy is used for a chemical reaction, either directly changing the absorbing molecule or photosensitizing a change in a nearby molecule, in which case, the absorbing molecule remains unchanged.

Table 1

UVC $(100-280 \mathrm{~mm})$ does not reach the earth's surface;

UVB $(280-315 \mathrm{~mm}):$

UVA $(315-400 \mathrm{~nm})$;

Visible light $(400-800 \mathrm{~mm})$ :

Infrared (P $800 \mathrm{~mm})$

Infrared (or heat) does not disrupt molecules but increases their vibration or rotation, assisting conventional chemical reactions. 
Microwave, radar, radio and television waves are of low energy and usually have very little effect. Short wavelength radiation, however, i.e. cosmic rays, X-rays, and gamma rays, is ionising and distupts atoms and molecules by completely dislodging electrons. Radiation from the sun is partly reflected, then modified and attenuated in the atmosphere by scattering and absorption. Short wavelength UVR is being scattered most, and ozone (formed by UVR from atmospheric oxygen) is the absorbet of UVR between 200 and $300 \mathrm{~nm}$. These processes are very important, since short-wave UVR below $297 \mathrm{~nm}$, is completely removed.

When UVR reaches the skin, it can be reflected, or transmitted into the skin. If transmitted, it is scattered and if absorbed, it may lead to chemical changes as described above. DNA, RNA, proteins, mucopolysaccharides, elastin, collagen and lyosomes can be damaged. DNA damage is probably the most important one, although damage to other factors may contribute to the effects of this damage."

\subsection{UV carcinogenesis}

Like most complete chemical carcinogens, UV light can both initiate and promote." Initiation implies the acquisition of a permanent genetic alteration conserved by daughter cells that subsequently predispose the cells to cancerous change. UV radiation can cause several types of genetic damage, including formation of DNA photoproducts (like pyrimidine dimers and 6-4 photopraducts), that most commonly result in $\mathrm{G} \rightarrow \mathrm{C}$ to $\mathrm{A} \rightarrow \mathrm{T}$ transitions at dipyrimidine sites, as well as single-strand breaks (primarily by UVA radiation exposure). ${ }^{4.5}$ Cyclobutane pyrimidine dimers (CPD) are the most frequent lesions produced in DNA by UV radiation."

Since the type of base substitutions $(\mathrm{C} \rightarrow \mathrm{T}$ and $\mathrm{CC} \rightarrow \mathrm{TT})$ are uniquely induced by UV irradiation, the presence of such mutations in human skin cancers implies that UV radiation is the carcinogenic agent in sunlight that led to the induction of mutations in p53 tumor suppressor gene. "This gene is altered early in skin carcinogenesis in thumans. ${ }^{8}$ Such mutations are detected in a diversity of skin cancers, supporting the concept of an etiologic role for ultraviolet radiation.

Epidermal p53 protein expression is associated with histological evidence of chronic sun damage, and $p 53$ protein is found in $A K$ and tissue immediately adjacent to $A K$." In UV-damaged human skin, this alteration is frequently an inactivation in an important tumor suppressor gene, such as p53, but it could also be an activating mutation in an oncogene, or inactivating alterations in a number of other umor suppressor genes.

Whether initiating or promoting effects predominate with UV light may vary depending on the circumstances of the exposure. Intense UV exposure may be more likely to lead to initiating mutations; chronic, lower-intensity (suberythemal) UV exposure may have a promoting effect. ${ }^{10}$

The first experimental evidence for a causal relationship between UV radiation and skin cancer came from animal experiments." Skin cancers have been induced experimentally with UVR in a variety of laboratory animals, including mice, rats, guinea. 
pigs, and opossums. "12.13 UV and UVB exposures add up arithmetically in skin cancer induction in hairless mice. ${ }^{14}$ In laboratory animals, UV radiation can act as a tumor initiator, as a tumor promotor, and a co-carcinogen by causing immune suppression. ${ }^{15}$ Recently it was shown that telomerase, whose activation plays a crucial role in the immortalization of human cells and carcinogenesis, is activated by $U{ }^{16}{ }^{16}$ In immortal neoplastic keratinocytes, telomerase is strongly upregulated. ${ }^{17}$

Many factors influence the induction of tumors by UV radiation; among different mouse strains, the same conditions of UV irradiation can produce tumors of different histologic types (SCC versus spindle cell tumors), different body sites (ears versus dorsal skin), and different latent periods. Other factors affecting UV carcinogenesis include the age at first irradiation, skim thickness and pigmentation, UV dose and regimen, and of course, the wavelength distribution of the UV light source.

The types of tumors vary depending on the species, but in mice they are usually SCC and an undifferentiated type of tumor usually classified as a spindle cell tumor or fibrosarcoma. In UV carcinogenesis, as in chemical carcinogenesis, there is a long latent period between first exposure and the appearance of primary skin tumors. Since the DNA damage induced by UV radiation is unique and differs from the lesions induced by any other carcinogen, it is most likely that UV-specific alterations (i.e., $\mathrm{C} \rightarrow \mathrm{T}$ and $\mathrm{CC} \rightarrow \mathrm{TT}$ ) in oncogenes and tumor suppressor genes isolated from skin tumors reflect reflect replication of unrepaired DNA. ${ }^{18}$ Thus the formation of DNA photoproducts by UV light is responsible for the induction of mutations and the development of skin cancer. Ultraviolet light can be absorbed directly by cellular macromolecules, leading to photochemical modification of DNA and proteins. Additionally, it also causes free radical formation, resulting in oxidative stress. ${ }^{19}$

Following exposure to UVR, p53 is increased in the skin, and may guard against UVinduced skin cancers in 2 ways. First, p53-mediated cell cycle arrest following UV exposure would allow time for repair of UV photoproducts that might otherwise lead to oncogenic mutations. Second, p53-mediated apoptosis eliminates keratinocytes that may have acquired premalignant or malignant characteristics prior to their clonal expansion. Defects in 53 provide a selective advantage for these cells by permitting them to survive multiple cycles of UV exposure. As p53 activity becomes impaired through mutation. failure to undergo cell cycle arrest may lead to additional p53 mutations and even greater resistance to apoptosis. Recently it was demonstrated that loss of wild-type p53 function predisposes mice (p53 deficient) to the development of squamous cell carcinomas after UV exposure. ${ }^{2 *}$

\subsubsection{UVB carcinggenesis}

Ultraviolet $B$ (UVB, 280-315 nm) exposure results in a variety of cellular insults including induction of CPD in DNA. Accumulation of these lesions can lead to mutations in critical genes and contribute to the development of NMSC.

DNA damage induced by ultraviolet light can be repaired while cells are arrested in the cell cycle. Tumor suppressor gene 53 has been implicated as being involved in the $\mathrm{Gl}$ arrest after UV irradiation. It has been indicated recently that p53 and retinoblastoma gene product ( $\mathrm{pRb}$ ) play an important role in the maintenance of the homeostasis of the 
epidermis after UV irradiation. ${ }^{21}$ P53 may play a role in both the repair of UVradiation-induced DNA damage and the induction of apoptosis, and may function as a central control checkpoint in response to UVB radiation induced DNA damage. ${ }^{22}$

Depletion of the ozone in the earth's atmosphere will increase the levels of UVB on the earth's surface and the risk of skin cancer. Mathematical models suggest an increase of 2 to 4 percent in the incidence of tumors for each 1 percent reduction in the ozone layer. ${ }^{23.24}$

\subsubsection{UVA carcinogenesis}

Although UVB is the major carcinogenic component of sunlight, ${ }^{25}$ part of the carcinogenicity of sunlight is due to the UVA in the solar spectrum. In addition, UVA radiation, the major component of UV radiation in sunlight (and tanning beds), can produce single-strand breaks in DNA that could lead to loss of heterozygosity (LOH) ${ }^{26}$ The damaging effects are additive to those of UVB. ${ }^{27}$ And it has been recently shown that UVA and UVB exposures add up arithmetically in skin cancer induction in hairless mice. The use of artificial UVA sources for cosmetic or medical purposes increases the total UV-carcinogenic load. Longer wavelength UVA radiation damages DNA and is carcinogenic in animals. Lavker et al showed, that UVAl $(340-400 \mathrm{~nm})$ was as effective as the entire UVA band $(315-400 \mathrm{~nm})$ at equal fluences in eliciting changes in these epidermal and dermal structures. ${ }^{28}$ In a subsequent study it has been shown that the UVA action spectrum for chronic dermal photodamage in humans may be flat and broad, extending up to $400 \mathrm{~nm}^{25}$ This was an unexpected finding since it has been generally assumed, primarily based on the acute erythema spectrum in humans, that UVA2 (315-340 nm) was more effective than UVA1 by at least 1 order of magnitude. ${ }^{30}$

\subsection{UV and BCC}

There is a general consensus amongst researchers which acknowledges solar ultraviolet radiation as the major carcinogenic agent for the development of skin cancers.

Although the relation between BCC and UV exposure of humans is evident, it has not been possible to induce any significant numbers of $\mathrm{BCC}$ in animals. For obvious ethical reasons experimental photo-carcinogenesis cannot be performed on man, therefore a mouse-model is often used. However, in extrapolating UV results from animals to humans one should take into account the differences between mouse and human skin. For example, the relative efficiencies for skin cancer induction by different wavelengths as determined in mouse models can be extrapolated to human skin by correcting for the differences in penetration in mouse versus human epidermis."

We now appreciate that the role of UV in the development of NMSC is 2-fold. First UV radiation causes mutations in cellular DNA which ultimately lead to unrestrained growth and tumor formation. Second, UV radiation has profound effects on the cutaneous immune system, inducing a state of relative immunosuppression that prevents tumor rejection.

Changing attitudes and lifestyles affecting sun exposure is deemed responsible for the upward trends in incidence of BCC and other skin cancer. 
In $\mathrm{BCC}$, mutations in the $p 53$ gene have been detected although the absolute rates of mutation vary between $10 \%$ and $90 \%$ in the various studies $32,33,34,35.36$

These mutations tend to cluster in so called "hot spots"37 along the p53 gene that represent sites of inefficient repair of pyrimidine dimers. Whether these p53 mutations occur as an early event or a late event in the pathogenesis of BCC remains unclear. It may be difficult to clarify this, because the majority of $\mathrm{BCC}$ do not arise from precursor lesions but rather appear de novo. ${ }^{38}$ However "recently it has been shown that in the epidemis adjacent to BCC in chronically sun-exposed epidermis, p53 accumulation is detectable, ${ }^{35}$ which suggests that p 53 mulation is an early event.

Chronic exposure to sunlight is responsible for $\mathrm{p} 53$ mutations and thus for subsequent $\mathrm{BCC}$ appearance, wheras acute UV exposure in childhood and adolescence might lead to early skin cancer development in genetically susceptible individuals via a p53 independent pathway.

It has also been shown that DNA repair capacity for ultraviolet light-induced damage is reduced in peripheral lymphocytes from patients with $\mathrm{BCC}$. Compared to controls, $B C C$ cases with selected risk factors had a relative decrease in DNA repair capacity of $10-28 \%$. These findings provide evidence that reduced DNA repair capacity is one of the underlying molecular mechanisms for sunlight-induced skin carcinogenesis in the general population.

\subsection{Immunologic factors}

Skin cancer develops owing to two separate mechanisms: Firstly, the UV-induced DNA damage in UV exposed cells, which can transform into tumor cells, and secondly, the deleterious effects of UV on the immune system, which is then unable to clear the tumor cells from the skin. These are interacting rather than separate mechanisms.

Damage to DNA results in dysregulation of cellular proliferation and initiates immune suppression by stimulating the production of suppressive cytokines. These cytokines contribute to the loss of immunosurveillance. UVR has both local and systemic immunosuppressive effects. Locally, it depletes and alters antigen-presenting Langerhans cells (LC) at the site of UV irradiation. Systemic suppression results when T(suppressor) cells are induced, by altered LC, by inflammatory macrophages that enter the skin following UVR, or by the action of cytokines. ${ }^{42}$

The majority of our information on the role of the immune system in UV carcinogenesis has come from studies on laboratory animals. There is increasing evidence that UV radiation causes immunological alterations in humans as well, and that the immune system is an important defense mechanism against the development of human skin cancer. $^{43.44}$

A summary of the evidence shows that acute, low-dose UVB protocols, which resemble quantitatively and qualitatively the manner in which human beings typically experience sun exposure, alter the cutaneous immune system in at least two important ways: they impair the induction of contact hypersensitivity to cutaneous antigens and induce 
antigen-specific tolerance. A varicty of immune responses such as contact bypersensitivity (CHS) and delayed-rype hypersensitivity (DTH) reactions are impaired after UV irradiation. Because the effects of UVB radiation on contact hypersensitivity induction are mimicked by intracutaneous injections of subinflammatory doses of tumor necrosis factor-alpha or cis-urocanic acid, a hypothesis to explain the mecha nism of action of UVB radiation in UVB susceptible individuals is that UVB dependent transfomation of trans- to cis-urocanic acid in the epidermis triggers the intracutaneous release of excess amounts of tumor necrosis factor-alpha. ${ }^{45}$ Alternatively, DNA damage in the form of cyclobutane pyrimidine dimers (CPD) can be the primary trigger for immune suppression by UV radiation. ${ }^{* 6}$

UV radiation causes the same type of morphological alterations in LC in human skin as it does in murine skin, ${ }^{47}$ and alterations in the proportions and functions of circulating leukocytes have been noted in normal human subjects after exposure to artificial and natural sources of UV radiation. ${ }^{48}$ In addition, there are changes in the antigen-presenting function of cells in human epidermis in response to suberythemal doses of UV radiation.

\subsection{UV-therapy in dermatology}

UVR has a medical use in the light treatment of a large number of dermatoses. The adverse effects of this treatment have to be considered, especially in younger patients. Patients treated with combined 8-methoxypsoralen and UVA (PUVA therapy) for psoriasis have a 12 times higher risk for developing SCC and a fourfold increased risk for $\mathrm{BCC}^{50} \mathrm{~A}$ statistically significant increaced incidence of $\mathrm{NMSC}$ was found for patients who thad received 100 or more PUVA exposures, and 250 or more $J / \mathrm{cm}^{2.51}$ Recently it was shown that both PUVA and UVB play a role in the development of skin cancer by inducing p53-mutations. 52

\subsection{UV-Protection}

The recognition of skin cancer as a preventable malignancy has implications for the health promotion role of all health care workers.

Prevention and public's education are the key factors against skin cancer. However, several studies have demonstrated that increasing the public's knowledge of the risks. of sun exposure does not necessarily alter personal behavior. ${ }^{53,54}$

In Australia, where there are high levels of ambient ultraviolet radiation and the highest incidence of skin cancer in the world, ${ }^{5 s}$ there is an obvious need to reduce both the occupational and recreational sun exposure of the population. The slip, slap, slop campaign has been known for a few years (slip into a shirt, slip under a tree, slap on a hat, and slop on some sunscreen).

Clothing has been promoted as a major sun protection measure for some time, yet its performance in this role has only recently been studied. The protective properties of 
fabrics and clothing against UVR have been known for some time, but recently there has been considerable interest in quantifying the degree of protection. ${ }^{56}$ An exciting innovation has been the use of an ultraviolet absorber which dramatically improves a garment's rating. In Australia, they are about to have the world's first standard for rating sun-protective clothing: the Ultraviolet Protection Factor (UPF). This is necessary because apparently some fabrics offer less protection than a sunscreen with SPF 15.57

A global network of stations to monitor UVB is now being established. This will make it possible to evaluate the major changes occurring in the environment that could influence the incidence of skin cancer. Paramount among these changes is the depletion of the layer of stratospheric ozone that provides the earth with a shield against UV.

Since many behaviors that increase the lifetime risk of skin cancer: sun exposure, sunburn, and lack of sun protection, occur early in childhood, public-awareness-programs should focus on protection of children and photoprotection education. ${ }^{58}$

\subsubsection{Sunscreens}

The skin possesses several characteristics designed to protect it against actinic damage: ${ }^{59}$

1) Thickening of the skin, which occurs following exposure to sunlight (UVB) is an important mechanism. This hyperplasia of the epidermis accurs by a rapid overactivity of the basal layer within 48 hours, causing thickening of the epidermis, particularly the stratum corneum, by up to several times. Hyperplasia thus leads to skin adaption in humans. This may reduce UVR penetration $(5-10$ fold) to the dermis and to the basal cell layer of the epidermis and may last for weeks. The skin thickening effects of UVA (e.g. by tanning beds) are insignificant.

2) Melanin is an excellent absorber of UV across the entire spectrum.

Immediate pignentation occurs in a few seconds by darkening of melanin precursors and bleached melanin already present in the epidermis. This lasts for minutes up to a few hours. This may possibly protect DNA of the basal layer of the epidermis. Action spectrum: UVA (and visible light).

Delayed tanning starts rapidly, but is not visible for about 2 days and peaks in $4-10$ days. It persists grossly for about the lifespan of the epidermis (30 days) except for remaining lifelong minor remnants. Melanin is effective because it absorbs UVB, UVA and visible light and it dissipates it as heat. A good tan may itself reduce UV penetration by about 2-4 times. Action spectrum for melanin production is UVC (minimally), UVB, and UVA.

To further protect the skin, the use of physical and chemical sunscreening agents has increased dramatically during the past two to three decades as an effective means of preventing sumburn (which is the basis of the SPF rating). In addition to preventing erythema, sunscreens can prevent DNA damage, ${ }^{00}$ and in particular, pyrimidine dimer formation. The active ingredients which are responsible for the effectiveness of sunscreens are described as being either physical or chemical. 
Table 2. Classification of physical and chemical sunscreens.

\begin{tabular}{ll}
\hline Physicial & \\
Zinc oxide \\
Titanium dioxide \\
Magnesium oxide \\
Calamine \\
Mica \\
Talc \\
Ziconium oxide \\
Chemical & \\
UVA-absorbers & \\
Oxybenzone & UVB-absorbers \\
Dioxybenzone & p-Aminobenzoic acid (PABA) \\
Menthyl anthranilate & Octyl p-methoxycinnamate \\
Methoxydibenzoyl methane & Octyl p-dimethylaminobenzoate \\
Sulisobenzone & Octyl salicylate \\
\hline
\end{tabular}

\section{Physical sunscreens}

Physical sunscreens/reflectants (containing zinc oxide, titanium dioxide, etc.) consist of insoluble pigments which are dispersed in the sunscreen film which is formed on the skin. Because they are insoluble, they simply form an opaque film over the site of application. Since the film is both opaque and compact the UVR is reflected and scattered before striking the skin. The sunscreens containing these agents, in adequate concentration are, in actual fact, the only preparations which deserve to be called 'total blocks'. They block both UVA and UVB.

\section{Chemical sunscreens}

The term 'soluble sunscreen' or absorbants (eg, p-aminobenzoic acid, benzophenone, methoxycinnemates, and salicylates) is used to describe those oil-soluble or watersoluble chemicals which are completely dissolved in the film formed on the skin by the product. These materials attenuate the intensity of the impinging radiation by absorbing the energy before it reaches the epidemis. They then re-emit this energy al a lower energy, which is essentially harmless, as fluorescence etc. Although a wide variety of chemicals possess the ability to absorb UVR, only a few possess the necessary qualifications to permit their use as sunscreens.

Many absorb in the wrong region of the UV-spectrum, others are unstable in the presence of radiation and still others are too irtitant to be suitable for use in solar protective preparations, or possess other undesirable properties.

Until recently the vast majority of sunscreens on the market contained only UVB absorbers, i.e agents which show their maximum absorption in the UVB region around $305-310 \mathrm{~nm}$, while permitting the unimpaired transmission of all radiation above approximately $320 \mathrm{~nm}$. These are compounds which are intended to lessen the intensity of the erythemogenic radiation while not interfering with the tanning radiation in the UVA region. UVA absorbers on the other hand, show their maximum absorption in those areas of the UV spectrum above about $320 \mathrm{~nm}$. They are commonly referred to as broad spectrum absorbers. 


\subsubsection{The absorption spectrum}

The ability of a UV-absorber in a sunscreen to block the transmission of UVR, depends upon the absorption spectrum of the absorber and its concentration in the sunscreen.

The absorption spectrum is the curve which shows the amount of UVR absorbed by the sunscreen-ingredient, at each particular wavelength. This absorption spectrum is different for different UV-absorbers. Some agents absorb more strongly than others at $300 \mathrm{~nm}$ and as a consequence can be used in lower concentrations.

Although the majority of sunscreen formulations contain only a single UVB absorber, (because of the desire to provide a product that will permit the skin to tan), evidence is now appearing that for a high level of UV protection, the sunscreen must block the transmission of UVA as well. In particular, UVA between $320-340 \mathrm{~nm}$ contributes to the erythema response.

A combination of absorbers to protect against both UVA and UVB is necessary in products designed to provide a high UV protection. Although the damaging activity of UVA is less potent there is a much higher intensity of this radiation in sunlight. Indeed, recent reports on the wavelength dependency for the induction of malignant melanoma in a fish model indicate that the efficacy of UVA wavelengths to induce malignant melanoma is orders of magnitude higher than would be predicted from the induction of erythema in man or NMSC tumor in mice. ${ }^{62}$ The suggestion might be made, therefore, that every sunscreen should contain a considerable concentration of an UVA absorber, in addition to an adequate concentration of an UVB absorber.

In order to provide the public with a means of knowing what level of protection a particular sunscreen might be expected to provide, government agencies have devised a scale based on what is known as the Sunscreen Protective Factor (SPF). The SPF value of a sunscreen is known to the public as a number on the label. The higher the $\mathrm{SPF}$ value, the greater the level of protection provided by the sunscreen (although this only is true for the same brand in the same country).

The SPF concept is primarily intended to indicate the ability of a sunscreen to prolong exposure without the danger of getting a severe sunburn. The time to produce an MED in the unprotected skin (lower back) is determined by using controlled conditions of exposure. A comparable area of skin is then covered with a uniform layer of the sunscreen 10 be tested (the amount applied is $2 \mathrm{mg} / \mathrm{cm}^{2}$, which provides for a $20 \mu \mathrm{m}$ film over the application site). The time required to produce the same perceptible level of erytherna through this film is then determined by giving a series of graded exposures. The ratio of these MED values is the SPF of the sunscreen, although it has been shown that the degree of protection (for photoaging) afforded by sunscreens does not precisely correlate with the SPF rating of the sunscreen. ${ }^{6 .}$

The prevention of erythema has been the focus of sunscreen use in the past. This is unfortunate because it has led to predictions on sunscreen potency based on this phenomenon, while it led others to presume that nothing of importance happens in the skin before the erythema threshold is reached. 


\subsubsection{Erythema as marker for UV-induced damage?}

Erythema is caused by an increased vasodilatation of dermal capillary vessels. The mechanism that causes this increased vasodilatation is most likely determined by a photochemical reaction in the epidermis, which results in the release of cytokines, arachdonic acid metabolites, and other pro-inflammatory mediators.

Although the action spectrum for erythema resembles the wavelength dependency of ultraviolet carcinogenesis in humans, ${ }^{64}$ it is a mistake to assume that erythema prevention is equal to prevention of all significant sun-related effects. In fact, many of the most significant UV effects occur before the erythema threshold is reached, including epidermal hyperplasia, inflammation, and changes associated with photoaging. ${ }^{65}$

The immunologic effects of suberythemous UV exposure include diminished antigen responsiveness and depletion of epidermal LC cells. ${ }^{66}$ Indications of DNA damage can also be seen after suberythematous UV exposure.

One of the crucial premutational lesions of UV-induced DNA-damage, the pyrimidine dimer, is known to occur after suberythematous doses. ${ }^{67}$ Furthermore it was shown that the erythemal response and $\mathrm{p} 53$ protein expression were not occurring concomitantly.

The p53 protein, (involved in growth arrest and apoptosis/programmed cell death in cells with irreparable DNA-damage) is induced by suberythematous UV exposure in significant levels in human epidermal cells. ${ }^{68}$

This p53 induction is a strong indication that DNA damage is occurring during suberythematous UV exposure. Sunburn cells provide corroboration that p53 induction is a marker for significant damage. These cells contain irreparably damaged DNA and have undergone p53-induced apoptosis. ${ }^{69}$ However, the most convincing evidence that suberythematous UVR exposure leads to significant DNA damage, is the fact that it causes skin tumors in mice. ${ }^{70,71}$

In the future a rating for DNA-damage prevention by sunscreens (i.e. p53-expression) and immunosuppression-protection will provide a more rational approach in skin cancer prevention.

\subsection{Future}

Topical application of alpha-tocopherol inhibits thymine dimer formation (in a dosedependent manner). ${ }^{22}$ This suggest that DNA photoprotection is an important mechanism by which topically applied alpha-tocopherol can inhibit UVB induced skin cancer. Several vitamin $\mathrm{E}$ compounds, including alpha-tocopherol acetate, alpha-tocopherol methyl ether, garnma-tocopherol, and delta-tocopherol also inhibit thymine dimer formation (but are five- to ten-fold less potent than alpha-tocopherol). Further studies are necessary for determining which forms of vitamin $E$ can inhibit specific lesions involved in skin carcinogenesis.

Deficiencies in DNA repair represent a potential risk for skin cancer development, and it is conceivable that one day DNA repair enzymes may be an important component of sunscreens. Reduction of ultraviolet-induced skin cancer in mice is possible by topical 
application of DNA repair enzymes. ${ }^{33}$ Application of liposomes containing the T4 endonuclease $V$, a CPD-specific DNA repair enzyme, almost completely protected mice from UV-induced systemic suppression of DTH, whereas UV-induced inflammation was only partially affected.

T4N5 liposomes may be a useful adjunct to sunscreens because thay can reduce some of the deleterious effects of UV radiation on skin even after a sunburn has been initiated. $^{74}$ 


\section{References}

1. Setlow RB. Repair deficient human disorders and cancer. Nature 1978;271:713 7 .

2. Kochevar I. Basic concepts in photobiology. In: Parrish JA, Kripke ML. Morison WL (Eds). Photoimmunology, Plenum Press, New York, 1983;pp 1-21.

3. Yuspa SH, Dlugosz AA. Cutaneous carcinogenesis: natural and expermental. In: Goldsmith LA. ed. Biochemistry and Physiology of the Skin. New York, NY: Oxford University Press Inc: 1991:1365-1402.

4. Drobetsky EA, Grosovsky AJ, Glickman BW. The specificity of UV-induced mutations at an endogenous locus in mammalian cells. Proc Natl Acad Sci USA 1987;84:9103-7.

5. Hutchinson $F$. Induction of tandem-base change mutations. Mutat Res 1994;309:11-5.

6. Tommasi S, Swiderski PM, Tu Y, et al. Inhibition of transcription factor binding by ultravioletinduced pyrimidine dimers. Biochemistry 1996;35:15693-703.

7. Leffell DJ, Brash DE. Sunlight and skin cancer. Sci Am 1996;275:52;356 9.

8. Jonason AS, Kunala S, Price GJ, et al. Frequent clones of p53-mutated keratinocytes in normal human skin. Proc Natl Acad Sci USA 1996;93:14025-9.

9. Einspahr J, Alberts DS, Aickin M, et al. Expression of p53 protein in actinic keratosis, adjacent, normal-appearing and non-sun-exposed human skin. Cancer-Epidemiol-Biomarkers-Prev $1997 ; 6: 583-7$.

10. Naylor MF. Erythema, skin cancer risk, and sunscreens. Arch Dermatol 1997;133:373-5.

11. Findlay GM, Ultraviolet light and sk in cancer. Lancet 1928;ii:1070-3.

12. Stenbäck F. Species-specific neoplastic progression by ultraviolet light on the skin of rats, guinea pigs, hamsters, and mice. Oncology 1975;31:209-25.

13. Ley RD, Applegate LA. Stuart TD and Fry RJM. UV radiation-induced skin tumors in Monow delphis domestica Photodermatol 1987;4:144-7.

14. Berg RJW, de Gruijl FR, van der Leun JC. Interaction between ultraviolet-A and ultraviolet-B radiations in skin cancer induction in hairless mice. Cancer Res 1993:53:4212-7.

15. Kripke ML, Fisher MS. Immunologic parameters of ultraviolet carcinogenesis. I Natl Cancer Inst 1976;57:211-5.

16. Ueda M, Ouhit A, Bito T, et al. Evidence for UV-associated activation of telomerase in human skin. Cancer Res 1997;57:370-4.

17. Parkinson EK, Newbold RF. Keith WN. The genetic basis of human keratinocyte immortalisation in squamous cell carcinoma development: the role of telomerase reactivation. Eur J Cancer $1997 ; 33: 727-34$

18. Urbach F. Evidence and epidemiology of UV-induced carcinogenesis in man. Natl Cancer Inst Monogr 1978;50:5-10.

19. Renzing J, Hansen S, Lane DP. Oxidative stress is involwed in the UV activation of p53. I Cell Sci 1996;109:1105-12.

20. Gang L. Tron V, Ho V. Induction of squamous cell carcinoma in p53-deficient mitce after ultraviolet irradiation. J Invest Dermato 199:8; | 1 10:72-5.

21. Ueda $M$, Ahmed NU, Bito $T$, et al. The expression of retinoblastoma protein in epidermis is induced by ultraviolet $B$ exposure. Br I Dematol 1996;135;406-11.

22. Cotton \$, Spandau DF. Ultraviolet B-radiation does influences the induction of apoptosis and p53 in human keratinocytes. Radiat Res 1997;147:148-55.

23. Fears TR, Scotto J. Estimating increases in skin cancer morbidity due to increases in ultraviolet radiation exposure. Cancer Invest 1983;1:19-26.

24. Henriksen T, Dahlback A, Larsen SH, Moan J. Ultraviolet radiation and skin cancer: effect of an ozone layer depletion. Photochem Photobiol 1990:51:579-82. 
25. Fitzpatrick TB, Sober AJ. Suntight and skin cancer. N Eng J Med 1985;321:1577-83.

26. Peak MJ, Peak JC. Carnes BA. Induction of direct and indirect single-strand breaks in human cell DNA by far- and near-ultraviolet radiations: action spectrums and mechanisms. Photochem Photobiol 1987;84:9103 7.

27. Kligman LH. Akin FJ, Kligman AM. J Invest Dermatol 1985;84:272-6.

28. Lavker RM, Veres DA, Irwin CJ, Kaidbey KH. Quantitative assessment of cumulative damage from repetitive exposures to suberythemogenic doses of UVA in human skin. Photochem Photobio 1995:63;348-52.

29. Lavker R. Kaidbey $K$. The spectral dependence for UVA-induced cumulative damage in human skin. I Invest Dermatol 1997; 108:17-21.

30. Mckinley AF, Diffey BL. A reference action spectrum for ultraviolet induced erythema in human skin. ClE J 1987:6:17-22.

31. de Gruijl FR, Forbes PD. UV-induced skin cancer in a hairless mouse model. BioEssays $1995: 17: 651-60$.

32. Rady P, Scinicariello, Wagner RF Jr, Tyring SK. P53 mutations in basal cell carcinomas. Cancer Res 1992:52:3804-6.

33. Moles JP. Moyret C, Guillot B, et al. P53 gene mutations in human epithelial skin cancers. Oncogene 1993;8:583-8.

34. Kubo $Y$, Urano $Y$, Yoshimoto K, et al. P53 gene mutations in human skin carncers and precancerous lesions: comparison with immunohistochemical analysis. J Invest Dermatol 1994;102:4404.

35. Campbel $\mathrm{C}$, Quinn AG, Angus B, Rees JL. The relation between p53 mutation and p53 immunostaining in non-melanoma skin cancer. Br J Dermatol 1993;129:235-41.

36. Brash DE, Rudolph JA, Simon JA, ef al. A role for sunlight in skin cancer: UV-induced p53 mutations in squamous cell carcinoma. Proc Natl Acad Sci USA 1991;88:10124-8.

37. Ziegler A, Leffell DJ, Kunala $S$, et all. Mutation hotspots due to sunlight in the p53 gene of nommelanoma skin cancers. Proc Natl Acad Sci USA $\llbracket 993 ; 90 ; 4216-20$.

38. Miller SJ. Biology of basal cell carcinoma (part IJ). J Am Acad Denmatol 1991;24:161-75.

39. Urano $Y$. Asano $T$, Yoshimoto $K$, et al. Frequent $p 53$ accumulation in the chronically sunexposed epidermis and clonal expansion of 553 mutant cells in the epidermis adjacent to basal cell carcinoma. J Invest Dermatol 1995:104:928-32.

40. D'Errico M, Calcugnile AS, Corona $R$, et al. P53 mutations and chromosome instability in basal cell carcinomas developed at an early or late age. Cancer Res 1997;57:747-52.

41. Wei Q. Matanoski GM, Farmer ER, et al. DNA repair capacity for ultraviolet light-induced datmage is reduced in peripheral lympocytes from patients with basal cell carcinoma. I Invest Dermatol 1995;104:933-6.

42. Strickland FM, Kripke ML. Immune response associated with nonmelanoma skin cancer. Clin Plast Surg 1997:24:637-47.

43. Boyle J, Mackie RM, Briggs JD, et al. Cancer, warts, and sunshine in renal transplant patients: a case-control study. Lancet 1984;1:702-5.

44. Yoshikawa T, Rae V, Bruins-Slot W, et al. Susceptibility to effects of UVB radiation on induction of contact hypersensitivity as a risk factor for skin cancer in humans. I Invest Dermatol $1990 ; 95: 530-6$.

45. Streilein JW. Taylor JR, Vincek $V$, et al. Relationship between ultraviolet radiation-induced immunostuppression and carcinogenesis. J Invest Dermatol 1994:103:107-11.

46. Kripke ML, Cox PA, Alas LG, Yarosh DB. Pyrimidine dimers in DNA initiate systemic immunosuppression in UV-irradiated mice. Proc Natl Acad Sci USA 1992;89:7516-7520.

47. Aberer W. Schuler G, Stingl G, et al. Ultraviolet light depletes surface markers of Langerhans cells. I Invest Dermatol 1981:76:202-10. 
48. Hershey $P$, Haran $G$, Hasic E, Edwards A. Alteration of $T$ cell subsets and induction of suppressor $T$ cell activity in normal subjects after exposure to sunlight. J Inmunol 1983:131:171-4.

49. Baadsgaard O, Fox D, Cooper KD. Human epidermal cells from ultraviolet hightexposed skin preferentially activate autoreactive $\mathrm{CD4} 2 \mathrm{H} 4$ suppressor-induced lynphocytes and $\mathrm{CD}$ + suppressor/cytotoxic lymphocytes. J Immunol 1988;140:1738-44.

50. Preston DS. Stern RS. Nonmelanoma cancers of the skin. N Eng J Medil 1992;327:1649-62.

51. MCKenna KE, Patterson CC, et al. Cutaneous neoplasia following PUVA therapy for psoriasis. BrJ Dermatol 1996;134:639-42.

52. Nataraj A.J, Wolf P, Cerroni L, Ananthaswamy HN. P53 mutation in squamous cell carcinonas from patients treated with psoralen + UVA (PUVA). J Invest Dermatol 199\%:109:238-43.

53. Hughes B, Altman DG, Newton JA. Melanoma and skin cancer: evaluation of a health edncation programme for secondary schools. Br I Dermatol 1993;128:412-7.

54. Cody $R_{*}$ Lee $C$. Behaviors, beliefs, and intentions in skin cancer prevention. I Behav Med $1990 ; 13: 373-89$.

55. Marks R, Staples M, Giles GG. Trends in non-melanocytic skin cancer treated in Australia: the second national surwey. Int J Cancer 1993;53:585-90.

56. Gies HP, Roy CR, McLennan A et al. UV protection by clothing: an intercomparison of measurements and methods. Health Phys 1997:73:456-64.

57. Davis S, Capjack L, Kerr N, Fedosejevs R. Clothing as protection from ultraviolet radiation: which fabric is most effective? Int I Dermatol 1997;36:374-9.

58. Buller MK, Goldberg G, Buller DB. Sun Smart Day: a pilot program for photoprotection education. Pediatr Dermatol 1997;14:257-63.

59. Magnus IA. Dermatological photobiology. Blackwell Scientific Publications, Oxford, 1976.

60. De Rijcke $S$, Heenen M. Decrease of ultraviolet induced DNA injury in human skin by $\mathrm{p}$-aminobenzoic acid esters. Dermatologica 1989;179:196-9.

61. Wolf $P$, Yarosh DB, Kripke ML. Effects of sunscreens and a DNA excision repair enzyme on ultraviolet radiation-induced inflammation, immune suppression, and cyclobutane pyrimidine dimer formation in mice. J Invest Dermatol $1993 ; 101: 523-7$.

62. Ley RD, Reeve VE. Chemoprevention of ultraviolet radiation-induced skin cancer. Environ Health Perspect 1997;105:981-4.

63. Bernstein EF, Brown DB, Tsunemichi T, et al. Evaluation of sunscreens with various sun protection factors in a new transgenente mouse model of cutaneous photoaging that measures elastín promotor activation. $J$ Am Acad Dermatol 1997;37:725-9.

64. De Gruijl FR, Van Der Leun JC. Estimate of the wavelength dependency of ultraviolet carcin. ogenesis in humans and its relevance to the risk assessment of a stratospleric ozone depletion. Health Phys 1994:67:319-25.

65. Imayama $S$, Nakamura $K$, Takeuchi $M$, et al. Ultraviolet $B$ irradiation deforms the configuration of elastic fibers during the induction of actinic elastosis in rats. J Dernatol Sci 1994;7:32-8.

66. Cooper $\mathrm{KD}$, Oberhelman L, Hamilton TA, et al. UV exposure reduces immunization rates and promotes tolerance to epicutaneous antigens in humans: relationship to dose, CDIaDR+ epidermal macrophage induction, and Langerhans cell deplettion. Proc Natl Acad Sci USA $1992 ; 89: 8497-501$.

67. Harber LC, Kochevar IE. Pyrimidine dimer formation and repair in haman skin. Cancer Res $1980 ; 40: 318: 1-5$.

68. Healy E, Reynolds NJ, Smith MD et al. Dissociation of erythema and p53 protein expression in human skin following UVB irradiation, and induction of $\mathrm{p} 53$ protein and mRNA following application of skin irritants. J Inwest Dermatol 1994;103:493-9.

69. Ziegler A, Johanson AS, Leffell DJ, et al. Sunburn and p53 in the onset of skin cancer. Nature $1994 ; 372: 773-6$ 
70. van Weelden H, van der Putte SC, Toonstra J, van der Leun JC. UVA-induced tumours in pigmented hairless mice and the carcinogenic risks of tanning with UVA. Arch Dermatol Res 1990:282:289-94.

71. De Gruijl FR, Van der Meer JB, Van der Leun JC. Dose-time dependency of tumor formation by chronic UV exposure. Photochem Photobiol 1 983;37:53-67.

72. McVean $M$, Liebller DC. Inhibition of UVB induced photodamage in mouse epidermis by topically applited alpha-tocopherol. Carcinogenesis 1997:18:1617-22.

73. Wolf P, Cox P, Yarosh DB, Kripke ML. Sunscreens and T4NS liposomes differ in their ability to protect against Uttrawiolet-induced sumburn cell formation, alterations of dendritic epidermal cells, and local suppression of contact hypersensitivity. J Invest Dermatal 1995:104:287-92.

74. Bito $T$, Ueda M, Nagano T, et al. Reduction of ultraviolet-induced skin cancer in mice by topical application of DNA excision repair enzymes. Photodermatol Photoimmunol Photomed 1995:11:9-13. 
Chapter 6

\section{DNA-protection by sunscreens: Using p53-immunostaining}

Eur J Dermatol 1997;7:259-62.

Gertruud Krekels, ' Christina Voorter, ${ }^{2}$ Foeke Kuik, ${ }^{3}$ Marc Verhaegh,

Frans Ramaekers, ${ }^{2}$ Martino Neumann'

1. Dermatology Department University Hospital Maastricht, the Netherlands,

2. Department of Molecular Cell Biology and Genetics, University of Limburg, Maastricht, the Netherlands,

3. Royal Netherlands Meteorological Institute, de Bilt, The Netherlands

This work was sponsored by a grant from: Household \& Personal Care Research, The Hague, The Netherlands 


\section{Summary}

P53 plays an important role in regulating the cell-cycle after exposure to DNA-damaging agents. It becomes immunocytochemically detectable in the epidermis and superficial dermal fibroblasts of normal adult human skin after exposure to doses of UV irradiation that induce mild sunburn (Hall et al, Oncogene 1993,8, 203).

We investigated the DNA-protective qualities of sunsereens (Zwitsal SPF 10 and Zwitsal SPF 20) as measured by p53 expression in skin biopsies, one day after a $1 / 2$ hours exposure to sunlight.

In all 25 healthy volunteers (skin types 1 to 3 ) a dramatic increase in p53 expression was found in the basal as well as the suprabasal cell compartment of the unprotected skin. Erythema was only seen in 19 of the 25 volunteers. The remaining six cases showed p53 expression without visible erythema. Therefore p53-expression might be a more sensitive parameter for UV induced skin damage.

Both sunscreens provided UV-protection as measured by the erythemal response, and as measured by the p53 response: a significantly lower fraction of cells were p53 positive as compared to the unprotected, UV-irradiated skin. Also the p53 expression levels were considerably lower in the sunscreen protected cells.

We conclude that p53 expression is a sensitive parameter in the detection of UVinduced damage in the skin, and suggest that it can be used to indicate the effectiveness of sunscreens (besides the SPF). 


\section{Introduction}

Skin cancer has become a serious health problem for Caucasians all over the world. The most common forms of non-melanoma skin cancer (NMSC), i.e. basal cell carcinoma (BCC) and squamous cell carcinoma ( $\mathrm{SCC}$ ), have an incidence almost as frequent as all other cancers combined. 'In the development of NMSC, UV light is a well documented and accepted factor. ${ }^{2}$ Therefore, to help bring the increasing numbers under control, prevention of extensive sun exposure has become an important item.

Ultraviolet B (UVB, $280-320 \mathrm{~nm}$ ), causes besides a suntan also sunburn, photoageing and skin cancer induction. Ultraviolet A (UVA, $320-400 \mathrm{~nm}$ ), is associated with the immediate tanning reaction, photoageing, and tumour promotion. The molecular mechanisms of these UV-induced effects are not completely understood. However, there is evidence that DNA-damage is involved in many biologic effects of UV radiation.

It is known that UV induces structural changes in cellular DNA, leading to an altered expression of oncogenes and tumour suppressor genes, such as $\mathrm{p} 53 .{ }^{3.4}$ NMSC show a high incidence of mutations in this gene. ${ }^{2}$ Wild-type p 53 is known to block the cellcycle, in order to allow DNA repair before its reduplication. Therefore this protein is also called the "guardian of the genome". type p53 in human epidermis after UV exposure is likely to be relevant in the prevention of skin carcinogenesis. ${ }^{.6}$

Wild-type p53 becomes immunohistochemically detectable in the epidermis and in superficial dermal fibroblasts of normal human skin after exposure to doses of UV irradiation that induce mild sunburn. ${ }^{7}$ Solar simulated light composed of UVA and UVB induces a rapid upregulation of p53 expression, starting within $4 \mathrm{~h}$ of mild UV exposure, with a peak at $24-48$ hours and a fall to undetectable levels by $360 \mathrm{~h}$. This mechanism of wild-type 533 induction by UV light probably relates to post-translational stabilization. ${ }^{8}$

The pattern of the p53 staining reaction in human skin was shown to be wavelength dependent ${ }^{9}$ : UVA gave predominantly staining in the basal cell layer, while UVB results in staining throughout the epidermis. Furthermore, it was found that the erythemal response and p53 protein expression were not occurring concomitantly: UVB doses that did not cause erythema, resulted in a significant increase of p53 protein levels in human epidermal cells. ${ }^{10}$

The use of high sun protection factor sunscreens, assessed by their ability to inhibit UV-induced erythema, is advocated to reduce skin cancer risk." Many studies of sunscreens, however, report that sunscreens that completely prevented erythema were either ineffective or only partially effective in preventing UV-induced immunosuppression both in humans and in mouse models. ${ }^{12}$ Other studies suggest that complete immunoprotection will be achieved only by using a higher sun protection factor than is necessary for the prevention of erythema. ${ }^{13}$ Sofar, only the protective effect for erythema has been semi-quantitatively indicated for the different sunscreens, by introduction of a sun protection factor (SPF), while a measure for their potential to prevent skin cancer, i.e. epidermal DNA protection or immunosuppression, is not yet established. 
The SPF is defined as the UV energy needed to produce minimal erythema (the minimal erythemal dose; MED) in sunscreen protected skin, divided by the MED of unprotected skin. The aim of this study was to investigate to what extent commercially available sunscreens provide DNA-protection, as measured in p53 expression.

\section{Materials \& Methods}

Twenty-five healthy volunteers entered this study, which was approved by the local Ethics Committee. Informed written consent was obtained from all participants. All volunteers (ages 21 to $35 ; 15$ female, 10 male) were Caucasian; nine with skin type 1; nine with skin type 2 ; and seven with skin type 3 .

Investigations were carried out on the buttocks or lower back. For at least two weeks prior to the experiment, these areas were not exposed to UV light exposure (artificial or natural). Three-millimeter punch biopsy specimens were taken under local anaesthesia from sunscreen protected and unprotected skin, before (controls) and $24 \mathrm{hrs}$ after sun exposure, immediately snap-frozen in liquid nitrogen and stored at $-70^{\circ} \mathrm{C}$.

Immediately before UV exposure, 2 skin areas were covered with a sunscreen. The two sunscreens (Zwitsal SPF 10, containing octyl methoxycinnemate and Zwitsal SPF 20 , containing titanium dioxide) provided by Kortman-Intradal, Den Haag, The Netherlands, were applied at an amount of $2 \mathrm{mg} / \mathrm{cm}^{2}$, each to one of these two skin areas. Another skin area was exposed to sunshine, without sunscreen protection.

The sunshine exposure time lasted $1 \frac{1}{2} \mathrm{~h}$ for twenty-one volunteers. Four volunteers with skin type 1 were exposed for only 1 hour. Twenty-four hours after UV exposure, punch biopsies were taken from the sunscreen-protected areas, as well as from the unprotected skin.

\section{UV Irradiation-conditions}

All spectral UV-measurements were performed on location at Scheveningen beach with a Brewer MKIIl (double monochromator) by the Royal Dutch Meteorological Institute, between 12:15 and 15:15, local time (local solar noon: 13:40 local time). The sunlight exposure started at 13:00 and lasted until 14:30. The temperature reached a maximum of $33^{\circ} \mathrm{C}$. All measured UV-spectra (from 286.5 to $365 \mathrm{~nm}, 0.5 \mathrm{~nm}$ increment) were weighted with the CIE or McKinlay-Diffey action spectrum ${ }^{14}$ and the socalled damaging UV (DUV) in $\mathrm{mJ}^{-2} \mathrm{~s}^{-1}$ was obtained. The amount of DUV for each spectrum is given in Table 1 . 


\begin{tabular}{|c|c|c|}
\hline $\begin{array}{l}\text { locall time } \\
\text { (hh:mm) }\end{array}$ & $\begin{array}{l}\text { DUV } \\
\left(\mathrm{m} / \mathrm{m}^{-z^{2}} \mathrm{~S}^{-1}\right)\end{array}$ & $\begin{array}{l}\text { Solar elevation } \\
(\mathrm{C})\end{array}$ \\
\hline $12: 14$ & 1111.2 & 55.9 \\
\hline $12: 25$ & 115.1 & 56.9 \\
\hline 12.34 & 117.8 & 57.5 \\
\hline 12.46 & 121.3 & 58.3 \\
\hline $13: 06$ & 124.8 & 59.3 \\
\hline $13: 30$ & 127.4 & 59.9 \\
\hline $13: 47$ & 127.7 & 59.9 \\
\hline $13: 55$ & 125.4 & 59.7 \\
\hline $14: 03$ & 121.2 & 59.5 \\
\hline $14: 20$ & 120.7 & 58.8 \\
\hline $14: 40$ & 119.9 & 57.6 \\
\hline $14: 48$ & 117.7 & 57.0 \\
\hline $15: 04$ & 1111.8 & 55.6 \\
\hline $15: 13$ & 105.6 & 54.7 \\
\hline
\end{tabular}

\section{Immunohistochemistry}

Serial 5- $\mu \mathrm{m}$ thick sections were cut from the frozen skin samples, using a cryostat at $30{ }^{\circ} \mathrm{C}$. The frozen sections were air dried overnight and fixed by dipping in acetone at room temperature. The sections were incubated with $0.3 \% \mathrm{H}_{2} \mathrm{O}_{2}$ in phosphate buffered saline (PBS), pH 7.2, for 20 min to block the endogenous peroxidase activity. The frozen sections were then incubated with a primary p53-antibody for $\| \mathrm{h}$ at room temperature. As primary p53 antibodies we used DO7, a mouse monoclonal antibody against recombinant human $p 53$ (Novocastra Laboratories Ltd. Newcastle, UK) and the mouse monoclonal antibody Bp53 (BioGenex, San Ramon, CA), diluted according to the manufacturers instructions. Nonspecific binding of antibodies was blocked by incubation with $5 \%$ normal goat serum. A rabbit peroxidase-conjugated anti-mouse secondary antibody was used (DAKO A/S, Glostrup, Denmark). The peroxidase reaction was developed using 3-3'-diaminobenzidine as a substrate for $8 \mathrm{~min}$. In negative controls the primary antibodies were omitted. The evaluation of the staining patterns was as follows: the staining intensity of 200 epidermal nuclei per biopsy was assessed by two independent observers and scored as - (no staining); + (weak staining); to - (moderate staining); and +++ (dark staining).

\section{Results}

Twenty-hours after sun exposure, distinct erythema was induced in the unprotected skin of nimeteen of the twenty-five volunteers (nine with skin type 1; eight with skin type 2 and two with skin type 3 ), while the skin sites pretreated with a sunscreen showed no erythema. 
P53 immunoreactivity patterns of the biopsy specimens are summarized in Table 2 and Figure 1. Examples of the staining reactions are depicted in Fig 2.

The non-exposed skin biopsies showed only a weak p53 expression, in a few scattered cells in the basal cell compartment. (Fig 1, columns a; Fig 2a).

On the contrary the unprotected, sun-exposed sites of all 25 volunteers, including the six cases without visible skin reddening, showed a variable p53 immunostaining in up to approximately $50 \%$ of the epidermal cells, with an average of $25 \%$ p53-positive epidermal cells.

Intense staining activity was seen in the basal and suprabasal cells (Fig 1, columns b; Fig 2 b) and a decreasing fraction of positive cells towards the skin surface. P53 expression in the sunscreen protected areas was comparable to our observations in non-exposed skin (Fig 1, columns $\mathrm{c}$ and $\mathrm{d}$, Figs $2 \mathrm{c}$ ).

It is evident from table 2 , that the fraction of p53-positive nuclei was significantly increased in the unprotected cells after sun exposure, as compared to the non-exposed skin. The sunscreens prowided a highly significant protection as concluded from the fact that p53 levels were not elevated as compared to the control.

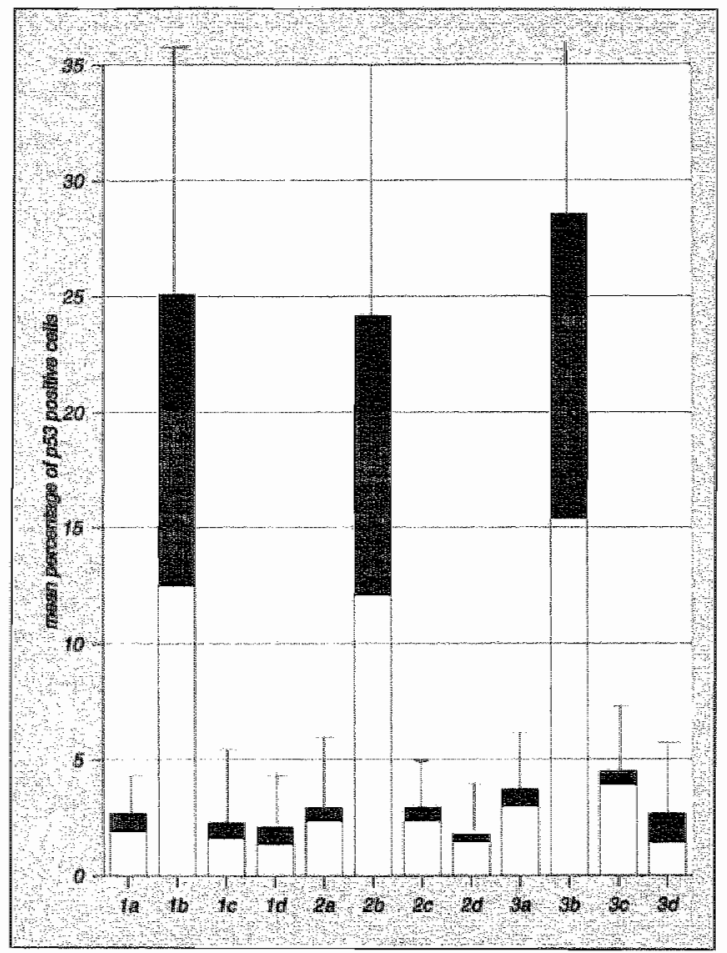

Figure 1: Schematic representation of the mean percentages of $p 53$ positive cells in skin types 1,2 and 3. The open part of the bars represents the mean percentage of weakly positive cells, the grey part the moderately positive cells and the closed part the strongly positive cells. The results are expressed as mean percentages is $\mathrm{SD}$.

a) ron-exposed skin, b) unprotected, exposed skin; c) Zwitsal SPF 10-protected, exposed skin: d) Zwitsal SPF 20-protected, exposed skin. 
Table 2. Results of the evaluation of 953 immunostaining reactions, presented as the mean number \pm SD of negative $(-)$, weakly positive $(+)$, moderately positive $(+-1)$ or strongly positive $(++4)$ cells out of 200 cells examined.

\section{Skin type 1}

Non-exposed

Exposed, unprotected

Exposed, SPF 10-protected

Exposed, SPF 20-protected

$\begin{array}{lcclc}- & + & + & ++ & \text { total }+ \\ 194.6 \pm 5.6 & 3.8 \pm 3.5 & 1.6 \pm 2.3 & 0 & 4.6 \pm 4.1 \\ 148.3 \pm 31.9 & 25.0 \pm 10.9 & 15.4 \pm 12.3 & 9.8 \pm 8.3 & 49.0 \pm 27.8 \\ 195.0 \pm 5.8 & 3.2 \pm 2.7 & 1.1 \pm 1.9 & 0.1 \pm 0.8 & 5.6 \pm 5.0 \\ 196.1 \pm 4.5 & 2.7 \pm 3.2 & 1.4 \pm 1.6 & 0.1 \pm 0.3 & 4.0 \pm 4.6\end{array}$

\section{Skin type 2}

Non-exposed

Exposed, unprotected

Exposed, SPF 10-protected

Exposed. SPF 20-protected

$\begin{array}{lrrlc}194.0 \pm 6.5 & 4.7 \pm 3.4 & 1.2 \pm 2.4 & 0 & 5.8 \pm 6.4 \\ 150.0 \pm 22.6 & 24.2 \pm 9.1 & 15.9 \pm 9.5 & 8.3 \pm 6.5 & 58.4 \pm 21.8 \\ 193.8 \pm 5.1 & 4.7 \pm 3.7 & 1.0 \pm 1.7 & 0.2 \pm 0.6 & 7.0 \pm 4.3 \\ 196.0 \pm 5.4 & 2.9 \pm 1.7 & 0.6 \pm 1.3 & 0.1 \pm 0.3 & 4.3 \pm 5.2\end{array}$

\section{Skin type 3}

Non-exposed

Exposed, unprotected

Exposed, SPF 10 -protected

Exposed, SPF 20-protected

$\begin{array}{lcr}191.5 \pm 4.4 & 6.0 \pm 4.2 & 1.0 \pm 2.0 \\ 143.3 \pm 29.7 & 30.8 \pm 16.8 & 18.5 \pm 4.0 \\ 191.0 \pm 5.5 & 7.8 \pm 4.5 & 1.2 \pm 1.5 \\ 194.8 \pm 7.1 & 2.8 \pm 2.7 & 1.5 \pm 3.0\end{array}$

$0.5 \pm 1.1 \quad 8.5 \pm 4.4$

$9.8 \pm 9.3 \quad 56.8 \pm 27.9$

0

$9.0 \pm 6.0$

$1.0 \pm 2.0 \quad 5.3 \pm 7.2$ 

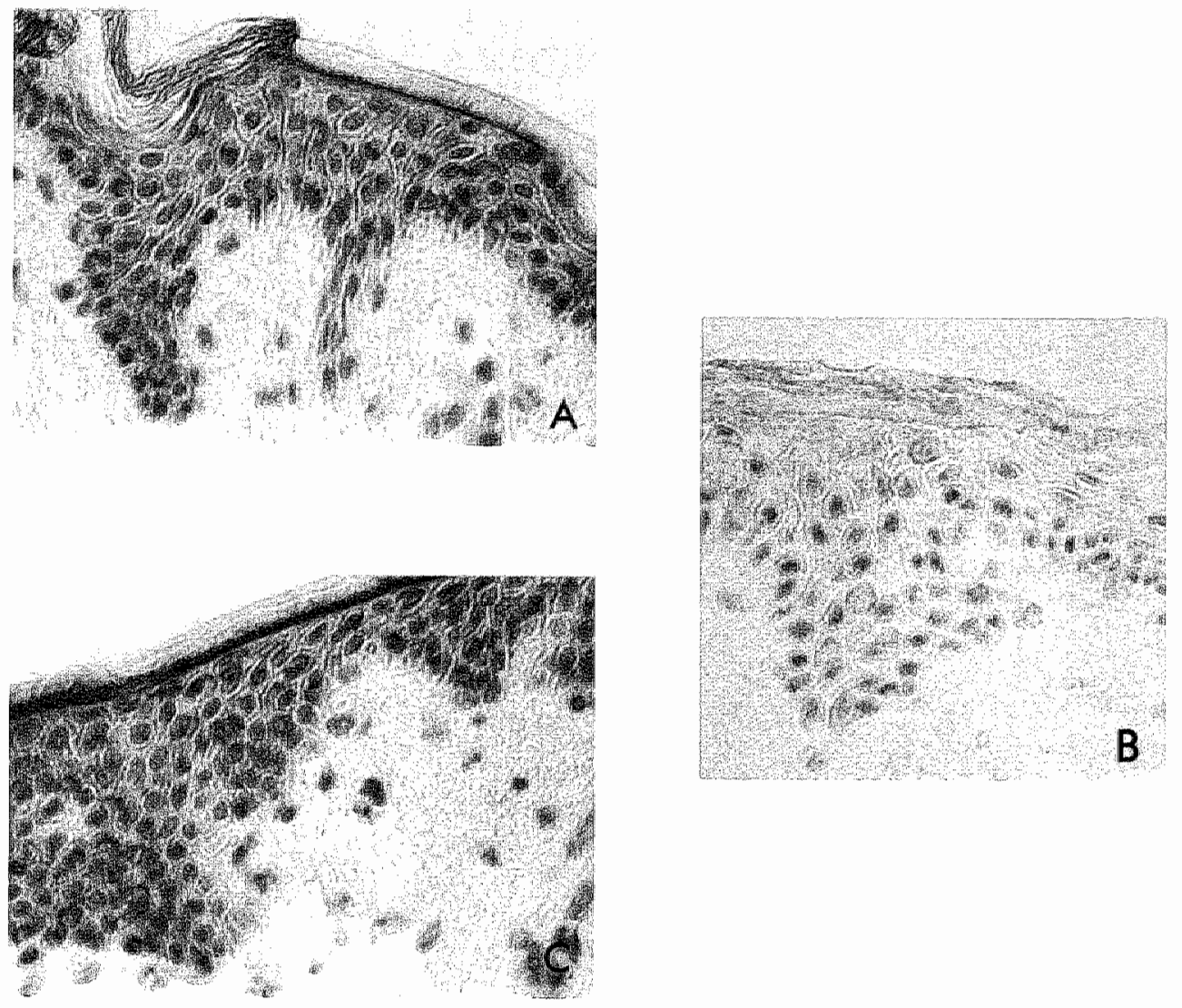

Figure 2:

P53 immunoperoxidase detection in

a) non-exposed skin;

b) unproteeted, exposed skin;

c)Zwitsal SPF 20-protected, exposed skin.

Magnification: $\times 200$. 


\section{Discussion}

Sunlight is a carcinogen to which everyone is exposed. Its UV component is the major epidemiologic risk factor for NMSC. Of the multiple steps in tumor progression, those that are sunlight-related would be revealed if they contained mutations specific to $U V$. Involvement of UV light in mutations in the p53 tumour suppressor gene is indicated by the presence of a $\mathrm{CC} \rightarrow$ TT double base change, which is only known to be induced by UV. These UV-like p53 mutations have been shown in NMSC. 2.4

Hall et al, have shown earlier an expression of wild-type p53 in the basal Jayer of the epidermis after exposure to doses of UV irradiation that induced mild sunburn. Thereafter Campbell et al, ${ }^{9}$ showed that this p53 expression in the epidermis is wavelength specific. Recently, Pontén and coworkers ${ }^{15}$ have studied a group of 5 volunteers with skin type 2-3 under solar simulation and showed that application of a sunscreen to the epidermis largely prevented p53 expression. We have elaborated on these findings by examining the DNA protective potential of sunscreens in twenty-five volunteers with skin types $1-3$ under natural sunshine conditions.

In this study we show that a brief exposure to natural sunlight causes an increase in p53 expression in the epidermis of Caucasians. No significant differences in p53 expression could be found in the various skin types. The two tested sunscreens ( $Z$ witsal SPF 10 and Zwitsal SPF 20) showed no increase in p53 expression, i.e. have a protective effect with respect to UV-induced DNA damage. From the fact that in the unprotected and UV-exposed areas of six volunteers, high levels of p53 were found, without erythema, we conclude that these two phenomena are independent and that p53-expression is a more sensitive marker of UV induced epidermal damage. In all the cases (19) were erythema was visible after unprotected UV-exposure, increased p53expression was found as well.

There are several indications that the acute erythema response following UV irradiation is independent of the p53 response. For example, erythema involves release of arachidonic acid from the cell. membrane and its subsequent catabolism in the cyclooxygenase pathway. Indomethacin, a potent inhibitor of cyclo-oxygenase. has been shown to cause significant suppression of acute phase erythema, but fails to alter UVB induction of p53 protein. ${ }^{17}$

Based on the foregoing, we propose to express the DNA-protective properties of sunscreens as the degree to which they prevent wild-type p53 expression. Sofar, the studies that applied this parameter have chosen a semi-quantitative approach, but in the future flow cytometric analysis of $p 53$ expression in the epidermis could provide a more accurate estimate of sunscreen effectiveness. 


\section{References}

1. Miller DL, Weinstock MA. Nonmelanoma skin cancer in the United States: incidence. J Am Acad Dermatol 1994;30:774-8.

2. Brash DE. Rudolph JA, Simon JA, al. A role for sunlight in skin cancer: UV-induced p53 mutations in squamous cell carcinoma. Proc Natl Acad Sci USA 1991;88:10124-8.

3. Tomalett $\mathrm{S}$, Pfeifer GP. Slow repair of pyrimidine dimers at p53 mutation hotspots in skin cancer. Science 1994;263:11436-8.

4. Ziegler $A_{4}$ Joriason AS, Leffell DJ et al. Sunbura and $p 53$ in the onset of skin cancer. Nature $1994 ; 372: 773-6$.

5. Lane DP. P53. guardian of the genome. Nature 1992;358:15-6.

6. Kamp A. Sun protection factor p53. Nature 1994;372:730 1.

7. Hall PA, McKee $\mathrm{PH}_{2}$ du Menage $\mathrm{P}$ et al. High levels of $\mathrm{p} 53$ protein in UV-irradiated normal human skin. Oncogene 1993;8:203-7.

8. Fritsche $M$, Haessler $C$, Brandner $G$. Induction of nuclear accumulation of the tumor-suppressor protein p53 by DNA-damaging agents. Oncogene 1993;8:307-18 .

9. Campbell C, Quinn AG, Angus B et al. Wavelength specific patterns of p53 induction in human skin following exposure to UV radiation. Cancer Res 1993;53:2697-9.

10. Healy E, Reynolds NJ, Smith MD et al. Dissociation of erythema and p53 protein expression in human skin following UVB irradiation, and induction of $\mathrm{p} 53$ protein and $\mathrm{mRNA}$ following application of skin irritants. J Invest Dermatol 1994;103:493-9.

11. Mackie RM, Elwood JM, Hawk ILM. Links between exposure to ultraviolet radiation and skin cancer. J R Coll Physicians Lond 1987;21:91-6.

12. Young AR, Walker SL. Photoprotection from UVR-induced immunosuppression. In: Krutmann J Elmets CA (eds.) Photoimmunology. Blackwell Science Ltd. London, 1995, pp 285. 297.

13. Walker SL, Young AR. Sunscreens offer the same UVB protection factors for inflammation and immunosuppression in the mouse. J Invest Dermatol 1997;108:133-8.

14. McKinlay AF, Diffey BL. A reference action spectrum for Ultra-Violet induced erythema in human skin, in W.F. Passchier and B.F.M. Bosnajakovid (eds), Human exposure to Ultravioler Radiation; Risks and Regulations. Elsevier, pp. 83-87 (1987).

15. Pontén F, Berne B, Ren Z.P. Ultraviolet light induces expression of $\mathrm{p} 53$ and $\mathrm{p} 21$ in human skin: effect of sunscreen and constitutive $\mathrm{p} 21$ expression in skin appendages. J Invest Dermatol 1995:105:402-6.

16. Black AK, Greaves MW, Hensby CN. Plummer NA. Increased prostaglandins E2 and $\mathbb{F} 2 \alpha$ in human skin at 6 and $24 \mathrm{~h}$ after ultraviolet B irradiation $(290-320 \mathrm{~nm})$. Br J Clin Pharmacol 1978:5:431-6.

17. Farr PM. Diffey BL. A quantitative study of the effect topical indomethacin on cutaneous erythema induced by UVB and UVC radiation. Br J Dermatol 1986;1 15:453-66. 


\section{Chapter 7}

\section{Dissociation between SPF and $\mathrm{p} 53$ protection by sunscreens}

Gertruud A.M. Krekels, Marie-Helene Lenders, Rick Hockzema, H.A.Martino Neumann, Frans C.S. Ramaekers (submitted for publication).

Dermatology Department, University Hospital Maastricht, The Netherlands. Molecular Cell Biology \& Genetics, University Maastricht, the Netherlands, 


\section{Summary}

Twelve volunteers took part in this study whose aims were to determine whether sunscreens with different SPF prevent induction of p53 expression (a marker for UV induced epidermal DNA-damage). We investigated the DNA-protective qualities of sunscreens (SPF 8, 30, and 40) as measured by p53 expression in skin biopsies, one day after an exposure to solar simulated UV expression.

In 12 volunteers (skin types 1 to 3 ) a dramatic increase in p53 expression was found in the basal as well as the suprabasal cell compartment of the unprotected exposed skin, while erythema was seen in only 10 of the 12 volunteers. The remaining 2 cases showed 53 expression without visible erythema.

All sunscreens provided UV-protection as measured by the erythemal response, and as measured by the p53 response: a significantly lower fraction of cells were p53 positive as compared to the unprotected, UV-irradiated skin. Also the p53 expression levels were considerably lower in the sunscreen protected cells. For SPF 8 however, a dissociation between erythema-induction and $\mathrm{p} 53$-expression was seen. 


\section{Introduction}

In the development of non-melanoma skin cancer (NMSC), ultraviolet radiation (UVR) is a well documented and accepted factor." The most widely used method of protection against the harmful effects of UVR is the use of topical sunscreens. Sunscreens prevent sunburn, ${ }^{2}$ photoaging, ${ }^{3}$ UV induced immune suppression, and UVB induced DNA damage. It has been shown that daily use of high-SPF sunscreens (i.e. SPF 17 or higher) prevents UV induction of precancerous actinic keratoses, ${ }^{6}$ and along with other sun-protection strategies, significantly reduces the cancer risk in xeroderma pigmentosum patients especially when initiated early in childhood.?

In order to provide the public with a means of knowing what level of protection a particular sunscreen might be expected to provide, government agencies have devised a scale based on what is known as the Sunscreen Protective Factor (SPF). The SPF value of a sunscreen is known to the public as a number on the label. The higher the SPF value, the greater the level of protection provided by the sunscreen (although this is true only for the same brand in the same country). Recently it was shown that sunscreens used on the beach do not protect against erythema (because most people do not use a thick enough layer of the sunscreen) and a new definition of SPF was proposed. Instead of the SPF-testing situation, where $2 \mathrm{mg} / \mathrm{cm}^{2}$ of a sunscreen is applied, the layer under real circumstances is much thinner. ${ }^{8}$

The SPF concept was primarily intended to indicate the ability of a sunscreen to prolong exposure without the danger of getting a severe sunburn. Erythema, or redness of the skin, is caused by an increased vasodilatation of dermal capillary vessels. The mechanism that causes this increased vasodilatation is most likely determined by a photochemical reaction in the epidermis, which results in the release of cytokines, arachdonic acid metabolites, and other pro-inflammatory mediators.

Sofar, only the protective effect for erythema has been semi-quantitatively indicated for the different sunscreens, by introduction of a SPF, while a measure for their potential to prevent skin cancer, i.e. epidermal DNA protection, is not yet established. The SPF is defined as the UV energy needed to produce minimal erythema (the minimal erythema dose; MED) in sunscreen protected skin, divided by the MED of unprotected skin. The time to produce an MED in the unprotected skin (lower back) is determined by using controlled conditions of exposure. The time required to produce the same perceptible level of erythema through this film is then determined by giving a series of graded exposures. The ratio of these MED values is the SPF of the sunscreen. although it has been shown that the degree of protection (for photoaging) afforded by sunscreens does not precisely correlate with the SPF rating of the sunscreen."

It is known that UV induces structural changes in cellular DNA, leading to an altered expression of oncogenes and tumor suppressor genes, such as p53..$^{10.11}$ NMSC show a high incidence of mutations in this gene. Wild-type p53 is known to block the cellcycle, in order to allow DNA repair before its replication. ${ }^{12}$ The induction of detectable levels of wild-type p53 in human epidermis after UV exposure is likely to be relevant in the prevention of UV induced skin carcinogenesis. "Wild-type p53 becomes immunohistochemically detectable in the epidermis and in superficial dermal fibroblasts of 
nomal human skin after exposure to doses of UV irradiation that induce mild sunburn. ${ }^{14}$ Solar simulated light composed of UVA and UVB induces a rapid upregulation of p53 expression, starting within $4 \mathrm{~h}$ of mild UV exposure, with a peak at 24-48 hours and a fall to undetectable levels by $360 \mathrm{~h}$. This mechanism of wild-type p53 induction by UV light probably relates to post-translational stabilization. ${ }^{15}$

The pattern of the p53 staining reaction in human skin was shown to be wavelength dependent ${ }^{16 .}$ UVA gave predominantly staining in the basal cell layer, while UVB results in staining throughout the epidermis. Furthermore, it was found that the erythemall response and p53 protein expression were not occurring concomitantly: UVB doses that did not cause erythema, resulted in a significant increase of p53 protein levels in human epidermal cells."

Recently, Pontén and coworkers have studied a group of 5 volunteers with skin type 23 under solar simulation and showed that application of a sunscreen to the epidermis largely prevented p 53 expression. ${ }^{18}$

The aim of this study was to investigate to what extent the prevention of erythema of the tested sunscreens (SPF 8,30 and 40) correlated to the DNA-protection, as measured in p53 expression.

\section{Materials \& Methods}

Twelve healthy volunteers entered this study, which was approved by the local Ethics Committee. Informed written consent was obtained from all participants. All volunteers (ages 21 to 35; 10 female, 2 male) were Caucasian; four with skin type 1; four with skin type 2 ; and four with skin type 3.

Investigations were carried out on the buttocks. For at least two weeks prior to the experiment, these areas were not exposed to UV light (artificial or natural).

Three-millimeter punch biopsy specimens were taken under local anaesthesia from sunscreen protected and unprotected skin, before (controls), immediately after and 24 hrs after sun exposure. These biopsies were immediately snap-frozen in liquid nitrogen and stored at $-70^{\circ} \mathrm{C}$.

\section{Solar Simulated imadiation}

15 Mimutes before solar simulated UV exposure (Solar Simulator UV 600 Model, 150 Watt Xenon short ARC lamp), 4 skin areas were covered with a sunscreen. The three sunscreens (SPF 8, 30, and 40 provided by Roc Colombes, France), were applied at an amount of $2 \mathrm{mg} / \mathrm{cm}^{2}$, which provides for a $20 \mu \mathrm{m}$ film over the application site, each sunscreen to one skin area. Another skin area was exposed to solar simulated UV, without sunscreen protection.

The solar simulated UV (UVA and UVB) was 1 MED on the unprotected area and 3 MED to the sunscreen-protected areas. Immediately after and twenty-four hours after UV exposure, punch biopsies were taken from the sunscreen-protected areas, as well as from the unprotected-irradiated skin. 


\section{Immunohistochemistry}

Serial $5-\mu \mathrm{m}$ thick sections were cut from the frozen skin samples, using a cryostat at $-30{ }^{\circ} \mathrm{C}$. The frozen sections were air dried ovemight and fixed by dipping in acetone at room temperature. The sections were incubated with $0.3 \% \mathrm{H}_{2} \mathrm{O}_{2}$ in phosphate buffered saline (PBS), $\mathrm{pH} \mathrm{7.2,} \mathrm{for} 20 \mathrm{~min}$ to block the endogenous peroxidase activity. The frozen sections were then incubated with a primary p53-antibody for $1 \mathrm{~h}$ at room temperature. As primary p53 antibodies we used D07, a mouse monoclonal antibody against recombinant human p53 (Novocastra Laboratories Ltd. Newcastle, UK) diluted according to the manufacturer's instructions. Nonspecific binding of antibodies was blocked by incubation with 5\% normal goat serum. A rabbit peroxidase-conjugated anti-mouse secondary antibody was used (DAKO A/S, Glostrup, Denmark). The peroxidase reaction was developed using 3-3'-diaminobenzidine as a substrate for 8 min. In negative controls the primary antibodies were omitted. The evaluation of the staining patterns was as follows: the staining intensity of 200 epidermal nuclei per biopsy was assessed by two independent observers and scored as - (no staining); + (weak staining); ++ (moderate staining); and +++ (dark staining).

\section{Results}

Twenty-four hours after solar simulated exposure, distinct erythema was induced in the unprotected skin of ten of the twelve volunteers (Four with skin type 1; four with skin type 2 and two with skin type 3), while the skin sites pretreated with a sunscreen showed no erythema. The results are shown in table $\mathbb{1}$ for the 3 skin types.

The non-exposed skin biopsies showed only a weak p53 expression, in a few scattered cells in the basal cell compartment.

On the contrary the unprotected, solar simulated exposed sites of all 12 volunteers, including the two cases without visible skin reddening, showed a variable p53 immunostaining in up to approximately $50 \%$ of the epidermal cells, with an average of $20 \%$ p 53 -positive epidermal cells. Intense staining activity was seen in the basal and suprabasal cells and a decreasing fraction of positive cells towards the skin surface. P53 expression in the sunscreen protected areas was comparable to our observations in non-exposed skin, for SPF 30 , and 40 . The sunscreens provided a highly significant protection as concluded from the fact that $\mathrm{p} 53$ levels were not elevated as compared to the control.

The area protected with SPF 8 showed an increase in p53 expression as compared to the unexposed skin, but provided an erythema protection as compared to the unprotected irradiated skin. The fraction of p53-positive nuclei was significantly increased in the unprotected skin after solar simulated exposure, as compared to the non-exposed skin. 
Table 1 . Resulis of the evaluation of $\mathrm{p} 53$ immunostaining reactions, presented as the mean number \pm $\mathrm{SD}$ of negatiwe $(-)$, weakly positive $(+)$, moderately positive $(++)$ or strongly positive $(+-t)$ cells out of 200 cells examined.

\begin{tabular}{|c|c|c|c|c|c|}
\hline & - & + & + & +4 & total + \\
\hline \multicolumn{6}{|l|}{ Skin type 1} \\
\hline Non-exposed & $195.9 \pm 3.3$ & $2.6 \pm 1.8$ & $1.5 \pm 1.6$ & 0 & $4.1 \pm 3.3$ \\
\hline $\mathbb{E x p o s e d , ~ u n p r o t e c t e d ~}$ & $148.3 \pm 19.1$ & $29.3 \pm 14$ & $15.1 \pm 5.7$ & $7.4 \pm 3.3$ & $51.8 \pm 19$ \\
\hline Exposed, +SPF 8 & $184.5 \pm 5.5$ & $9.1+3.4$ & $4.6 \pm 2.0$ & $1.8 \pm 1.2$ & $15.5 \div 5.5$ \\
\hline Exposed, +SPF 30 & $195.0 \pm 3.1$ & $3.5 \pm 1.7$ & $1.4 \pm 1.4$ & $0.1 \pm 0.3$ & $5.0 \pm 3.1$ \\
\hline Exposed, +SPF 40 & $196.6 \pm 2.1$ & $2.4 \pm 1.4$ & $0.9 \pm 0.8$ & 0 & $3.3 \pm 2.0$ \\
\hline \multicolumn{6}{|l|}{ Skin type 2} \\
\hline Non-exposed & $194.5 \pm 4.1$ & $4.4 \pm 3.2$ & $1.1 \pm 1.1$ & 0 & $5.5 \pm 4.1$ \\
\hline Exposed, unprotected & $150.1 \pm 19.5$ & $24.2+9.3$ & $18.6 \pm 6.5$ & $7.0 \pm 4.3$ & $49.9 \pm 19$ \\
\hline Exposed, +SPF 8 & $189.9 \pm 5.6$ & $5.9+2.5$ & $3.3 \pm 1.5$ & $1.0 \pm 1.1$ & $10.1 \pm 4.6$ \\
\hline Exposed, +SPF 30 & $194.6 \pm 2.2$ & $3.9 \pm 1.3$ & $1.3 \pm 1.0$ & $0.3 \pm 0.7$ & $5.4 \pm 2.2$ \\
\hline Exposed, +SPF 40 & $195.8 \pm 3.3$ & $3.3 \pm 2.6$ & $0.9 \pm 0.8$ & $0.1+0.3$ & $4.3 \pm 3.3$ \\
\hline \multicolumn{6}{|l|}{ Skin type 3} \\
\hline Non-exposed & $193.4 \pm 3.9$ & $4.8 \pm 2.9$ & $1.4 \pm 1.1$ & $0.5 \pm 0.7$ & $6.6 \pm 3.9$ \\
\hline Exposed, unprotected & $143.0 \pm 23.6$ & $31.8 \pm 14.6$ & $18.3 \pm 6.7$ & $7.6-14.3$ & $57.6 \pm 23$ \\
\hline Exposed, +SPF 8 & $188.4 \pm 2.5$ & $6.6 \pm 0.9$ & $4.0 \pm 1.4$ & $1.0 \pm 0.9$ & II. $1.2 \pm 2.5$ \\
\hline Exposed, +SPF 30 & $193.5 \pm 3.7$ & $5.1 \pm 2.8$ & $1.4 \pm 1.0$ & 0 & $6.5 \pm 3.7$ \\
\hline Exposes, $+S P F 40$ & $194.8+2.8$ & $3.6+1.8$ & $1.6 \pm 1.3$ & 0 & $5.3 \pm 2.8$ \\
\hline
\end{tabular}

\section{Discussion}

The prevention of erythema has been the focus of sunscreen use in the past. This is unfortunate because it has led to predictions on sunscreen potency based on this phenomenon, while it led others to presume that nothing of importance happens in the skin before the erythema threshold is reached.

Although the action spectrum for erythema resembles the wavelength dependency of ultraviolet carcinogenesis in humans, ${ }^{19}$ it is a mistake to assume that erythema prevention is equal to prevention of all significant sun-related effects. In fact, many of the most significant UV effects occur before the erythema threshold is reached, including epidermal hyperplasia, inflammation, and changes associated with photoaging. ${ }^{20}$

From our three tested sunscreens (SPF 8, 30, and 40), SPF 8 showed a minor increase in p53 expression, as compared to the unexposed skin. The SPF 30 , and 40 showed no increase in p53 expression, i.e. have a protective effect with respect to UV-induced DNA damage. From the fact that in the unprotected and UV-exposed areas of two volunteers, high levels of p53 were found, without erythema, we conclude that these two phenomena are partly independent and that 553 expression may be a more sensitive marker of UV induced epidermal damage. In all the cases (I0) where erythema was visible after umprotected solar simulated UV-exposure, increased p53-expression was found as well. 
There are several indications that the acute erythema response following UV irradiation is independent of the $\mathrm{p} 53$ response. For example, erythema involves release of arachidonic acid from the cell membrane and its subsequent catabolism in the cyclooxygenase pathway. ${ }^{21}$ Indomethacin, a potent inhibitor of cyclo-oxygenase, has been shown to cause significant suppression of acute phase erythema, but fails to alter UVB induction of $\mathrm{p} 53$ protein. ${ }^{22}$

Earlier data on UV-induced immune suppression, ${ }^{23}$ suggested that less DNA-damage is required to cause UV-induced immune suppression than to cause sunburn. Immune suppression and inflammation are different effects of UV radiation and involve different mechanisms. The ability of sunscreens to provide immunoprotection is critically dependent on the UVB treatment. ${ }^{24}$ The immunologic effects of suberythemous UV exposure include diminished antigen responsiveness and depletion of epidermal LC cells. ${ }^{25}$

Indications of DNA-damage can also be seen after suberythematous UV exposure. One of the crucial premutational lesions of UV-induced DNA-damage, the pyrimidine dimer, is known to occur after suberythematous doses. ${ }^{26}$ Furthermore it was shown that the erythemal response and $\mathrm{p} 53$ protein expression were not occurring concomitantly. The p53 protein, (involved in growth arrest and apoptosis/programmed cell death in cells with irreparable DNA-damage) is induced by suberythematous UV exposure in significant levels in human epidermal cells. ${ }^{27}$

This p53 induction is a strong indication that DNA damage is occurring during suberythematous UV exposure. Sunburn cells provide corroboration that 553 induction is a marker for significant damage. These cells contain irreparably damaged DNA and have undergone p53-induced apoptosis. ${ }^{28}$ However, the most convincing evidence that suberythematous UVR exposure leads to significant DNA damage, is the fact that it causes skin tumors in mice. ${ }^{29}$

The ability of a UV-absorber in a sunscreen to block the transmission of UVR, depends upon the absorption spectrum of the absorber and its concentration in the sunscreen. The absorption spectrum is the curve which shows the amount of UVR absorbed by the sunscreen-ingredient, at each particular wavelength. This absorption spectrum is different for different UV-absorbers. Some agents absorb more strongly than others at $300 \mathrm{~mm}$ and as a consequence can be used in lower concentrations. A combination of absorbers to protect against both UVA and UVB is necessary in products designed to provide a high UV protection. Although the damaging activity of UVA is less potent, there is a much higher intensity of this radiation in sunlight. Indeed, recent reports on the wavelength dependency for the induction of malignent melanoma in a fish model indicate that the efficacy of UVA wavelengths to induce melanoma is orders of magnitude higher than would be predicted from the induction of erythema in man or NMSC tumor in mice. ${ }^{30}$ Although the majority of sunscreen formulations contain only a single UVB absorber, (because of the desire to provide a product that will permit the skin to $\tan$ ), evidence is now appearing that for a high level of UV protection, the sunscreen must block the transmission of UVA as well. In particular, UVA between $315-340 \mathrm{~nm}$ contribute to the erythema response. 
The suggestion might be made, therefore, that every sunscreen should contain a considerable concentration of an UVA absorber, in addition to an adequate concentration of an UVB absorber.

Based on the foregoing, we propose to express the DNA-protective properties of sunscreens as the degree to which they prevent wild-type p53 expression: a p53protection-factor. Sofar, the studies that applied this parameter have chosen a semiquantitative approach, but in the future flow cytometric analysis of p53 expression in the epidermis could provide a more accurate estimate of sunscreen effectiveness. In the future a rating for DNA-damage prevention by sunscreens (i.e. p53-expression) and immunosuppression-protection will provide a more rational approach in skin cancer prevention. 


\section{Conclusions}

In twelve tested healthy volunteers (four with skin type 1, four with skin type 2 and four with skin type 3), the tested sunscreens (Roc SPF 8,30 and 40) protect against UV induced DNA damage as measured in p53 response as well as in erythemal response, up to at least 3 MED. However, the SPF 8 protected irradiated skin showed a minor increase in p53 expression as compared to the unirradiated skin, while no erythemal response was observed. Compared to the unprotected irradiated skin, SPF 8 still provided a good protection. The SPF 30 and 40 protected irradiated skin samples showed no increase in p53 expression at all, i.e. have an excellent protective effect with respect to UV-induced DNA damage.

The results showed that high SPF (30 and 40 ) sunscreens provide adequate levels of DNA-damage protection as measured in p53 expression. Lower SPF sunscreens protect against DNA-damage as well, however DNA damage may occur (even without an erythemal response). These data demonstrate furthermore the importance of sunscreens in skin cancer prevention. 


\section{References}

1. Brash DE, Rudolph JA, Simon JA, et al. A role for sunlight in skin cancer: UV-induced p53 mutations in squamous cell carcinoma. Proc Natl Acad Sci USA 1991;88:10124-8.

2. Pathak MA. Sunscreens: topical and systenic approaches for protection of human skin againsï harmful effects of solar radiation. J Am Acad Dermatol 1982;7:285-312.

3. Kligman LH. Protective effect of sunscreens against photoaging. Drug Cosmetic Industry $1985 ; 137: 30-4$.

4. Roberts LK, Beasley DG. Commercial sunscreen lotions prevent ultraviolet radiation induced immune suppression of contact hypersensitivity. I Invest Dermatol 1995;105:339-44.

5. van Praag MCG, Roza L, Boom BW, et al. Determination of the photoprotective efficacy of a topical sunscreen against UVB-induced DNA darnage in human epidermis. J Photachem Photobiol B 1993;19:129-34.

6. Thompson SC, Jolley D, Marks R. Reduction of solar keratoses by regular sunscreen use. N Eng $J$ Med 1993;329:1147-51.

7. Kondoh M, Ueda M, Nakagawa K, Ichihashi M. Siblings with xerodema pigmentosum complementation group $\mathrm{A}$ with different skin cancer development: importance of sun protection at an early age. J Am Acad Dermataol 1994;31:993-6.

8. Wulf H-C, Stender I-M, Lock-Andersen J. Sunscreens used at the beach do not protect against erythema: a new definition of SPF is proposed. Photodermatol Photoimmunol Photomed 1997;13:129-32.

9. Bernstein EF, Brown DB, Tsunemichi $T$, et al. Exaluation of sunscreens with various sun protection factors in a mew transgenenic mouse model of cutaneous photoaging that measures elastin promotor activation. I Am Acad Dermatol 1997;37:725-9.

10. Tornaletti S, Pfeifer GP. Slow repair of pyrimidine dimers at p5.3 mutation hotspots in skin cancer. Science 1994:263:1436-8.

11. Ziegler $A_{3}$ Jonason AS, Leffell DJ et al. Sunburn and $p 53$ in the onset of skin cancer. Nature $1994 ; 372: 773-6$.

12. Lane DP. P53, guardian of the genome. Nature 1992;358:15-6.

13. Karmp A. Sun protection factor p53. Nature 1994;372:730-1.

14. Hall PA, Mckee PH, du Menage $\mathrm{P}$ et al. High levels of $p 53$ protein in UV-irradiated normal human skin. Oncogene 1993;8:203-7.

15. Fritsche $M$, Haess fer $C$, Brandner $G$. Induction of nuclear accumulation of the tumor-suppressor protein 553 by DNA-damaging agents. Oncogene 1993:8:307-18.

16. Compbell C, Quim AG, Angus B et al. Wavelength specific patterns of p53 induction in human skin following exposure to UV radiation. Cancer Res 1 993;53:2697-9.

17. Healy $\mathbb{E}$, Reynolds NJ, Smith MD et al. Dissociation of erythema and 553 protein expression in human skin following UVB irradiation, and induction of $p 53$ protein and mRNA following application of skin irritants. J lnwest Dematol 1994:103:493.9.

18. Ponten F, Berne B, Ren Z-P. Uttraviolet light induces expression of $p 53$ and $\mathrm{p} 21$ in human skin: effect of sunscreen and constitutive p21 expression in skin appendages. I Invest Dematol 1995:105:402-6.

19. De Gruijl FR, Van Der Leun JC. Estimate of the wavelength dependency of ultraviolet carcinogenesis in humans and its relevance to the risk assessment of a stratospheric ozone depletion. Health Phys 1994;67:319-25.

20. Imayama $S$, Nakamura $K$, Takeuchi $M$, et al. Ultraviolet- $B$ irradiation deforms the configuration of elastic hibers during the induction of actinic elastosis in rats. J Dermatol Sci 199:47:32-8.

21. Black AK, Greaves MW. Hensby CN, Plummer NA. Increased prostaglandins E2 and F2a in human skin at 6 and 24 h after ultraviolet $B$ irradiation $(290-320 \mathrm{~nm})$. Br J Clin Pharmacol 
$1978 ; 5: 431-6$.

22. Farr PM, Diffey BL. A quantitative situdy of the effect topical indomethacin on cutaneous erythema induced by UVB and UVC radiation. $\mathrm{Br}$ J Dermatol 1986:115:453-66.

23. Wolf P, Yarosh DB, Kripke ML. Effects of sunscreens and a DNA excision repair enzyme on ultraviolet radiation-induced inflammation, immune suppression, and cyclobutane pyrimidine dimer formation in mice. J Invest Dermatol 1993:101:523-7.

24. Hurks HMH, Van der Molen RG, Out-Luiting $C$, et al. Differential effects of sunscreen on UVB-induced immunomodulation in humans. J Invest Dermatol 1997;109:699-703.

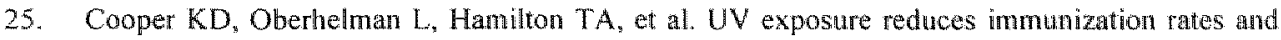
promotes tolerance to epicutaneous antigens in humans: relationship to dose, CDIaDR+ epidermal macrophage induction, and Langerhans cell depletion. Proc Natl Acad Sci USA 1992;89:8497-501.

26. Harber LC. Kochevar IE. Pyrimidine dimer formation and repair in haman skin. Cancer Res $1.980 ; 40: 31811-5$.

27. Healy $\mathbb{E}$, Reynolds NJ, Smith MD et al. Dissociation of erythema and $p 53$ protein expression in human skin following UVB irradiation, and induction of $p 53$ protein and mRNA following application of skin irritants. JInvest Dermatol 1994;103:493-9.

28. Ziegler A, Johanson AS, Leffell DJ, et al. Sunburn and p53 in the onset of skin cancer. Nature $1994 ; 372: 773-6$

29. De Gruijl FR, Van der Meer JB, van der Leun JC. Dose-time dependency of tumor formation by chronic UV exposure. Photochem Photobiol 1983;37:53-67.

30. Ley RD, Reeve VE. Chemoprevention of ultraviolet radiation-induced skin cancer. Environ Health Perspect 1997;105:981-4. 

Chapter 8

\section{Induction of DNA-damage by sunbeds, as assessed by epidermal p53 expression}

G.A.M. Krekels, P. Werner, M-H Lenders, R Hoekzema, H.A.M. Neumann, P. Nelemans, F.C.S. Ramaekers. (Submitted for publication).

Dermatology Department, University Hospital Maastricht, the Netherlands.

Molecular Cell Biology \& Genetics, University Mastricht, Maastricht, the Netherlands,

Department of Epidemiology, University Maastricht, the Netherlands

This study was sponsored by the Dutch Consumer Association 


\section{Summary}

One hundred and fifty volunteers took part in this study whose aims were to determine whether mild exposure to UV radiation by commercially available sunbeds induces epidermal DNA damage as measurable in p53. Each volunteer was exposed to two taming devices (one on the front; one on the back) for 9 consecutive days. On day 0 and day 10 skin biopsies were taken from the front and the back, and skin color (reduction in luminance, $\Delta L$ ) was measured. Wild-type p53 was immunohistochemically assessed in biopsies before and after UV exposure.

We found that those sumbeds that produced the best tanning results (pigmentation or reduction in luminance), induced the most epidermal p53 expression.

Since both UVA and UVB radiation induce DNA damage, and are associated with the induction of skin cancer, the use of sumbeds may impose a serious health risk for frequent users. 


\section{Introduction}

The social appeal of a tanned skin is apparent and many people associate a bronzed body with good health and a sense of well-being. This has led to a blooming and still growing suntan industry. UV facilities are used at home (over $10 \%$ of the Dutch households own a UV tanning device) and in commercial establishments like tanning sallons, hairdresser"s shops, fitness centres, swimming pools, holiday centres etc. With this growing popularity of artificial tanning lamps, the concern about risks associated with their use has increased as well.

UVA radiation ( $315-400 \mathrm{~nm}$ ) has been supposed to be harmless while it can tan at high dosages, therefore tanning devices are composed of high power UVA sources with little emission of UVB. UVB radiation (280-315 nm) is generally considered to be the most deleterious and carcinogenic component of sunlight. 'However, animal experiments have proven that chronic UVA irradiation can induce skin damage, including skin cancer. ${ }^{2,34}$ UVA is able to penetrate further into the dermis than UVB and is far more prevalent in daily sunlight. While UVB produces damage predominantly via the direct absorption of DNA, UVA is not absorbed directly, but may damage DNA through the generation of reactive oxygen species. Types of damage include singlestrand breaks and DNA protein cross-links. This so called endogenous oxidative damage is suspected to be a major contributor to forms of cancer and aging. ${ }^{5}$ We know that UVA is certainly a causative factor in photoaging. ${ }^{6}$ Recently it was shown that commercial tanning lamps produce the types of DNA damage associated with photocarcinogenesis in human cells. ${ }^{7}$ The risk assessment of the DNA damage induced by natural sunlight and different tanning lamps is based on MED (minimal erythemal dose) measurements. Because erythema is predominantly a response to UVB, MED numbers reveal very little about the UVA induced damage.

Solar simulated light composed of UVA and UVB induces a rapid upregulation of p53 expression, starting within $4 \mathrm{~h}$ of mild UV exposure, with a peak at 24-48 hours and a fall to undetectable levels by $360 \mathrm{~h}$. This mechanism of wild-type p 53 induction by UV light probably relates to post-translational stabilization. ${ }^{8}$ Under physiological circumstances, the wild-type $\mathrm{p} 53$ protein has a very short half-life and is present in such small quantities that it is not immunohistochemically detectable. 9.10 Wild-type p53 becomes immunohistochemically detectable in the epidermis and in superficial dermal fibroblasts of normal human skin after exposure to doses of UV irradiation that induce mild sunburn." Wild-type p53 is known to block the cell cycle, in order to allow DNA repair before its replication. Therefore this protein is also called the "guardian of the genome". ${ }^{12}$ It performs several functions that include initiating apoptosis if DNA damage is excessive, and acting as a transcription factor regulating the expression of other growth-regulating genes. The induction of detectable levels of wild-type p53 in human epidermis after UV exposure is likely to be relevant in the prevention of skin carcinogenesis. ${ }^{13}$ High SPF sunscreens provide DNA-damage-protection as measered by 553 -response. ${ }^{14}$

The pattern of the $\mathrm{p} 53$ staining reaction in human skin was shown to be wavelength dependent ${ }^{15}$ : UVA gave predominantly staining in the basall cell layer, while UVB results in staining throughout the epidermis. Furthermore, it was found that the erythe- 
mal response and 53 protein expression were not occuring concomitantly, since UVB doses that do not cause erythema, resulted in a significant increase of p53 protein levels in human epidernal cells.

To assess DNA damage by UVAVVB combinations in commercially available tanning beds we examined p 53 expression in human skin. For this purpose 150 healthy wolunteers were exposed to 20 different UV-sources for 9 consecutive days.

\section{Materials and Methods}

One hundred and fifty healthy volunteers (individuals with skin types I, II and III; 120 female, 30 male, ages $20-42 \mathrm{y}$ ), who had no history of previous skin disease, were taking no photosensitizing drugs, and had not exposed the buttock skin to direct sunlight or tanning devices for over two months were recruited. All subjects reviewed and signed an informed consent form detailing the investigation prior to enrollment.

\section{Irradiation protocol:}

Groups of 15 volunteers ( 5 with skin type 1; 5 with skin type 2 and 5 with skin type 3 ) were assigned to 20 different sumbeds. UV sources and UVA and UVB in $\mathrm{mW} / \mathrm{m} 2$ are given in table 1 . Each volunteer was exposed to two tanning devices for 9 consecutive days. One UV device irradiated the front, another the back. Irradiation on day one and two lasted for $5 \mathrm{~min}$; on day three and four: $10 \mathrm{~min}$; day five, six and seven: $15 \mathrm{~min}$; day eight and nine: 20 minutes.

Three-millimeter punch-biopsies were taken from the buttocks/lower back or abdominal skin under local anaesthesia on day 0 and day 10 and immediately stored at $-70^{\circ} \mathrm{C}$.

\section{Immunohistochemistry:}

Serial $5 \mu \mathrm{m}$ thick sections were cut from the frozen samples using a cryostat at $-30{ }^{\circ} \mathrm{C}$. The frozen sections were air dried overnight and fixed by dipping in acetone at room temperature. The sections were incubated with $0.3 \% \mathrm{H}_{2} \mathrm{O}_{2}$ in phosphate buffered saline (PBS), pH 7.2, for 20 min to block endogenous peroxidase activity. The frozen sections were then incubated with the primary p53-antibody for 1 h at room temperature. As primary 53 antibodies we used DO7, a mouse monoclonal antibody against recombinant human p53 (Novocastra Laboratories Lid. Newcastle, UK) and the mouse monoclonal antibody Bp53 (BioGenex, San Ramon, CA), diluted according to the manufacturer's instructions. Nonspecific binding of antibodies was blocked by incubation with $5 \%$ normal goat serum. A rabbit peroxidase-conjugated anti-mouse secondary antibody was used (DAKO A/S, Glostrup, Denmark). The peroxidase reaction was developed using 3-3'-diaminobenzidine as a substrate for $8 \mathrm{~min}$. In negative controls the primary antibodies were omitted.

The evaluation of the staining patterns was as follows: the staining intensity of 200 epidermal nuclei per biopsy was assessed by two independent observers and scored as - (to staining); + (weak staining); ++ (moderate staining); and +++ (strong staining). 
Tanning and Erythema measurements:

The Minolta tri-stimulus colorimeter CR-300 was used as described before, ${ }^{17}$ to quantify the effect of the UV-exposure. Colorimetric measurements were carried out on day 0 and on day 10. The colorimetric parameters used were $L^{*}$ (luminance), $a^{*}\left(+a^{*}\right.$ is the red direction, $-a^{*}$ is the green direction) and $b^{*}\left(+b^{*}\right.$ is the yellow direction, and $-b^{*}$ is the blue direction).

\section{Results}

UV treatment caused a signifanct increase in the number of $\mathrm{p} 53$ positive nuclei in the epidermal cells. The results of the different sunbeds (for the p 53 increase and (delta) $\Delta \mathrm{L}^{*}, \Delta \mathrm{a}^{*}$ and $\left.\Delta \mathrm{b}^{*}\right)$ are shown in Table 1 .

The p53 immunoreactivity patterns are depicted in fig la and $\mathrm{lb}$.

Two biopsy specimens from a single volunteer are depicted in Fig la (prior to UV exposure) and $\mathrm{lb}$ ( $24 \mathrm{hrs}$ following the 9 th exposure).

Prior to UV-exposure, only a few cells showing weak staining for p53 were observed scattered in the basal cell compartment of individuals with either skin type I, II or III. In UV-exposed sites variable (moderate to strong) staining for $\mathrm{p} 53$ was found in up to $20 \%$ of the epidermal cells, with an average of $10 \%$ of cells being positive. Staining was most pronounced in the basal cells.

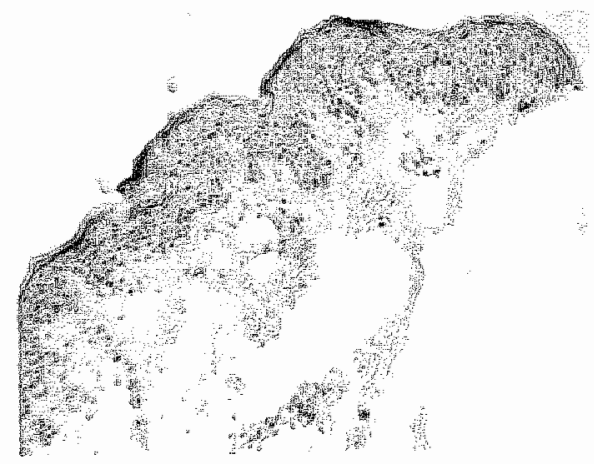

Fig la: before UV exposure

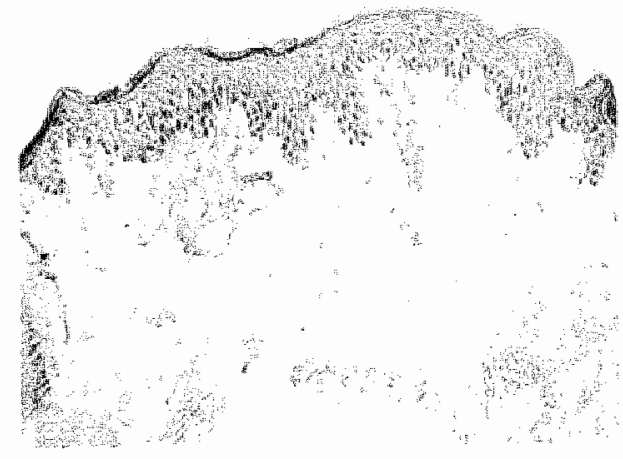

Fing 1 b: after a nine-days raning session 
Table 1

$\begin{array}{llllll}\text { UVB } & \text { UVA } & \Delta \mathrm{L}^{*} & \Delta \mathrm{a}^{*} & \Delta \mathrm{b}^{*} & \Delta \mathrm{p} 53 \\ W / \mathrm{m}^{2} & W / \mathrm{m}^{2} & & & & \\ 0.07 & 68.0 & -2.93 & 1.41 & 0.26 & 9.93 \\ 0.13 & 26.6 & 1.45 & -0.51 & -0.28 & 7.07 \\ 0.17 & 28.1 & -1.41 & 0.35 & 0.16 & 13.92 \\ 0.23 & 45.9 & -3.55 & 0.39 & 1.00 & 7.67 \\ 0.28 & 62.8 & -1.71 & 0.50 & -0.36 & 21.79 \\ 0.30 & 70.2 & -1.13 & 0.43 & 0.62 & 10.14 \\ 0.33 & 76.0 & -2.45 & 1.37 & 0.57 & 11.86 \\ 0.34 & 75.3 & -2.89 & 1.36 & 0.17 & 11.53 \\ 0.37 & 31.9 & -1.64 & 0.97 & 1.59 & 8.73 \\ 0.37 & 75.6 & -4.92 & 2.53 & 2.26 & 16.53 \\ 0.37 & 82.2 & -5.07 & 1.54 & 0.48 & 10.60 \\ 0.38 & 32.3 & -0.30 & -0.16 & 0.03 & 8.22 \\ 0.38 & 82.3 & -3.22 & 1.76 & 1.42 & 23.87 \\ 0.39 & 92.4 & -5.99 & 1.79 & 0.41 & 20.87 \\ 0.41 & 35.5 & -1.41 & 0.35 & 0.16 & 13.92 \\ 0.49 & 120.6 & -6.58 & 1.42 & -1.58 & 19.80 \\ 0.51 & 120.2 & -5.03 & 2.02 & 2.01 & 15.80 \\ 0.52 & 123.1 & -8.47 & 2.93 & 1.57 & 18.67 \\ 0.59 & 140.5 & -5.28 & 3.16 & 1.71 & 24.13 \\ 0.60 & 136.1 & -5.25 & 3.30 & 0.69 & 18.50 \\ 0.81 & 170.1 & -7.61 & 1.83 & 0.14 & 18.40\end{array}$

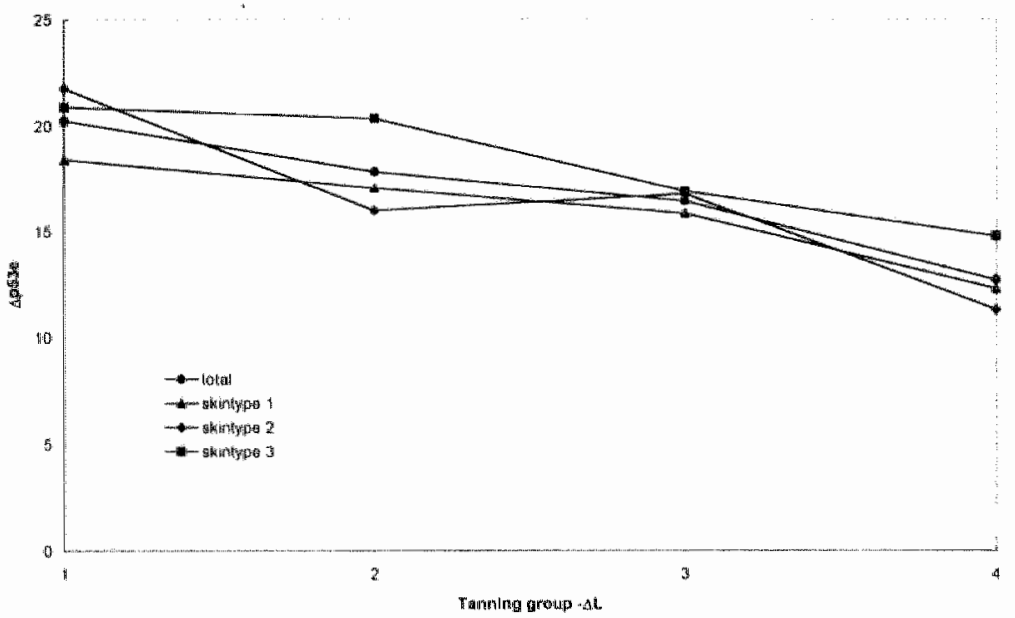

Figure 2a. $\Delta p 53$ e versus tanning group for various skin types.

In figures $2 a$ and $2 b$ the results are shown for the p53 increase against the different tanning groups. (Fig $2 \mathrm{a}$ are the results of the abdominal tanning; fig $2 \mathrm{~b}$ shows the results for the tanning on the buttocks). We devided volunteers into four groups according to quartiles of $\Delta \mathrm{L}$ (these values of $\Delta \mathrm{L}$ together with the median devide the data 
into four equally populated subgroups). Group 1, (the group with the highest tanning ($\Delta L$ ) showed the highest p53-response. The capacity of sumbeds to induce a tan clearly correlated with the degree of nuclear p 53 staining in the epidermis.

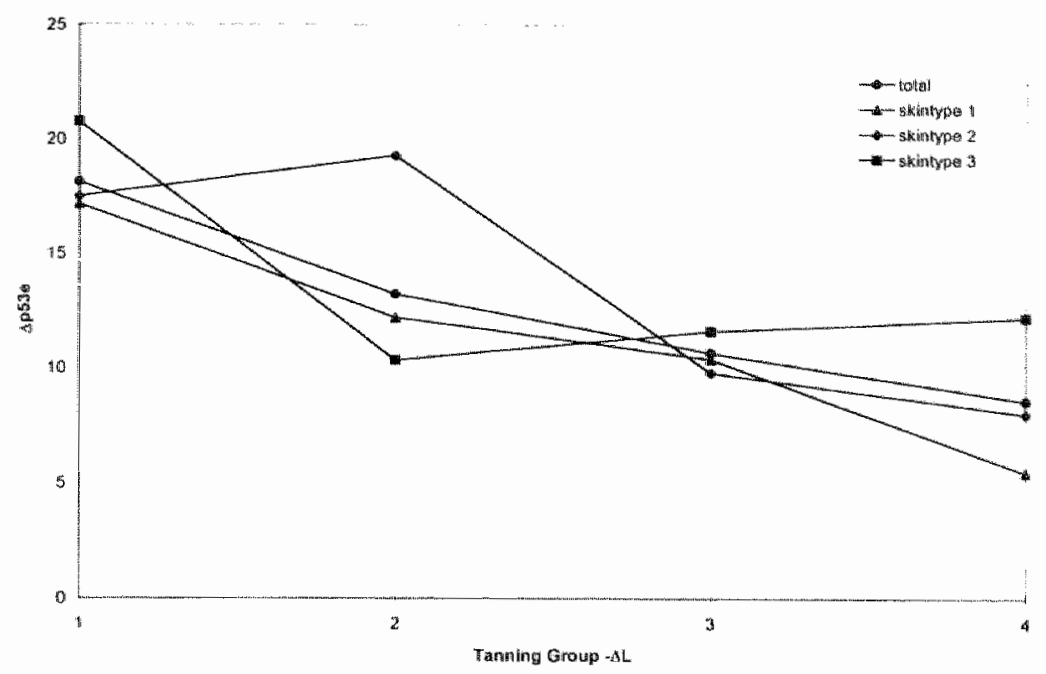

Figure $2 \mathrm{~b} . \Delta \mathrm{p} 53 \mathrm{e}$ versus tanning group for various skin types.

\section{Statistics}

We used Analysis of Variance (ANOVA) and Univariate Regression Analysis. We devided volunteers into four groups according to quartiles of $\mathrm{dL}$ (these values of $\mathrm{dL}$ together with the median devide the data into four equally populated subgroups). We used analysis of variance (ANOVA) to test whether the differences in p 53 between the subgroups were significant (front: $p=0.053$; back $p=0.008$ ). To assess the relationship between $\mathrm{dL}$ and $\mathrm{p} 53$ we used univariate regression analysis. The $\beta$-coefficient for the front $=-0.67(95 \% \mathrm{Cl}$ between -1.18 and -0.16$)$ and for the back $-1.03(95 \% \mathrm{Cl}$ between -1.57 and -0.49$)$ both significant $(\alpha=0.05)$.

\section{Discussion}

Skin cancer is a worldwide public health problem. It is significant that the vast majority of such cases can be prevented in the future by simply reducing the polulation's exposure to UV Radiation. Population-based surveys have shown that most sunbed users believe that a tan acquired by sunlight is less safe than one acquired by UVA tanning lamps, ${ }^{18}$ although there is evidence that a tan acquired by UVA tanning lamps is less protective than tan produced by UVB or natural sunlight. ${ }^{19}$ Much information 
exists on UVB carcinogenesis. However UVA is present in sunlight all day, year-round and in amounts that are 100-1,000 times greater than UVB.

Nowadays it is possible for humans to absorb more UVA radiation than is normally possible by sun exposure alone: high intensity sources of UVA are now widely used in tanning salons and for home usage; and the majority of sunsicreens are more effective in blocking UVB than UVA. The use of sumbeds seems to be correlated with excessive tanning by sunlight ${ }^{20}$ In a study among $14-19$ year old adolescents $57 \%$ reported sunbed use, and $44 \%$ of all sunbed users, reported sunbed erythema. ${ }^{2}$ The use of sunbeds is not only harmfull for skin but can cause serious effects on the eyes as well, especially because protective goggles are often not used. ${ }^{22}$

DNA lesions mediated by UVA (the major component of UV radiation in sunlight and tanning beds) comprise cyclobutyl pyrimidine dimers, (6-4) photoproducts and single strand breaks that can lead to loss of heterozygosity, ${ }^{23}$ and may lead as UVB to altered expression of oncogenes and tumor suppressor genes, such as p53. ${ }^{24,25}$ Importantly, the p53 gene is itself a frequent target of mutation in UV carcinogenesis of the skin. Cells carrying mutant p53 genes may undergo clonal expansion in the carcinogenesis process, as evidenced by immunostaining mutant p53 proteins in premalignant lesions. Mutant p53 genes isolated from nonmelanoma skin cancers and premalignant lesions exhibit charactaristic "fingerprint" mutations associated with UV damage, consisting of $\mathrm{C}$ to $\mathrm{T}$ and $\mathrm{CC}$ to TT transitions. ${ }^{26}$ Recently p53 mutations were found in squamous cell carcinomas from psoriasis patients treated with PUVA. ${ }^{27}$

The damaging effects of UVA are additive to those of UVB. ${ }^{28.29}$ It has been shown that UVA and UVB exposures add up arithmatically in skin cancer induction in hairless mice. ${ }^{30}$ UVA alone can produce skin tumors in mice, and the dose relationships are quite well defined. $^{31}$

Long-term exposure to UVA tanning beds can lead to changes commonly seen in association with chronic radiation damage, ${ }^{32}$ and is correlated to the development of non-melanoma skin cancer, ${ }^{33}$ and even malignant melanoma, especially in younger individuals. ${ }^{34.35}$

An essential factor in evaluating the consequences of UVA radiation is to consider the extent to which people are exposed. The mutagenicity of UV-radiation (sources) can be compared on the basis of the mutation induction per MED. Because erythema is predominantly a response to UVB, MED numbers reveal very little about the UVA induced damas by tanning lamps. Different skin types, make it even more difficult to compare erythema-responses. Studies in the albino mouse also indicate a dissimilarity between the action spectra for cancer induction and erythema. ${ }^{36}$

The epidermal action spectra is likely to be dissimilar to the acute erythemal action spectrum. Therefore, great care should be taken in making predictions of long-term UV effects on the basis of the acute erythema action spectrum.

A more rational approach in the prediction of skin cancer risk is to use a marker for epidermal damage at the (sub)cellular level i.e. p53 protein as a marker for UV-mediated DNA-damage.

In this study we showed that sunbeds induce an increase in epidermal p53 expression, as a result of UV-induced DNA damage and that this was more pronounced for those 
sunbeds that induced measurable tanning. Based on the rising numbers of skin cancer and the results of this and earlier studies, the use of sumbeds should be strongly discouraged by doctors and other health care workers. The p53-DNA-damage-marker may be the tool to convince the general public as well as professionals that exposure to sunbeds is a serious health risk. 


\section{References}

1. Vorbew PD. Photocarcinogenesis: an overview. J Invest Dermatol 1981;77:139-43.

2. Applegate LA, Scaletta C, Fourtanier A el al. Expression of DNA damage and stress proteins by UVA irradiation of human skin in wivo. Eur J Dermatol 1997;7:215-9.

3. de Laat A, van Kranen HJ, van der Leun JC. de Gruijl FR. Photocarcinogenesis by UVA (365 nm) radiation. Eur I Dermatol 1997;7:220-2.

4. Kelfkens $\mathrm{G}$, De Oruij| FR, Van der Leun JC. Tumourigenesis by short-wave ultraviolet-A : Papillomas versus squamous cell carcinomas. Carcinogen 1991;12:1377-82.

5. Ames BN, Shigenaga MK. Oxidants are a major contributor to cancer and aging. In: DNA and Free Radicals (Halliwell B, Aruoma O1, eds). Chichester: Ellis Horwood Limited, 1993:1-9.

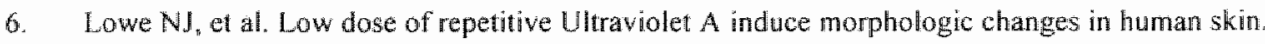
J Invest Dermatol 1995;105:739 43 .

7. Woollons $\mathrm{A}$, Clingen $\mathrm{PH}$, Price $\mathrm{ML}$, et al. Induction of mutagenic DNA damage in human fibroblasts after exposure to artificial tanning lamps. Br J Dermatol 1997;137:687-92.

8. Fritsche $M$, Haessler $C$, Brandner $G$. Induction of nuclear accumulation of the tumor-suppressor protein p53 by DNA-damaging agents. Oncogene 1993;8:307-18.

9. Hall PA, Lane DP, P53 in tumour pathology: can we trust immunohistochemistry? J Pathol $1994 ; 172: 1-4$.

10. Greenblat MS, Bennet WP, Hollstein M, Harris CC. Mutations in the p53 tumor suppressor gene: clues to cancer etiology and molecular pathogenesis. Cancer Res 1994;54:4855-78.

11. Hall PA, McKee $P H$, du Menage P, al High levels of p53 protein in UV-irradiated normal human skin. Oncogene 1993;8: 203-7.

12. Liane DP. P53, guardian of the genome Nature 1992;358:15-6.

13. Kamb A. Sun protection factor p53. Nature 1994:372:730-1.

14. Krekels GAM, Voorter C, Kuik F, et al. DNA-protection by sunscreens: p53-immunostaining. Eur J Dermatol 1997:7:259-62.

15. Campbell C, Quinn AG, Angus B et al. Wavelength specific patterns of $p 53$ induction in human skin following exposure to UV radiation. Cancer Res 1993;53:2697-9.

16. Healy $\mathrm{E}$, Reynolds NJ, Smith MD, et al. Dissociation of erythema and $\mathrm{p} 53$ protein expression in human skin following UVB irradiation, and induction of $p 53$ protein and mRNA following application of skin irritants. J Invest Dermatol 1994;103:493-9.

17. Westerhof W, wan Hasselt BAAM, Kanmeijer A. Quantification of UV-induced erythema with a portable computer controlled chromameter. Photodermatology 1986:3,310-4.

18. Lillquist PP. Baptiste MS, Melissa A, el al. A population-based survey of sun lamp and tanning parlor use in New York State, 1990. J Am Acad Dernatol 1994;31:510-2.

19. Gange RW, Blackett AD, Matzinger BA et al. Comparitve protection efficiency of UVA and UVB induced tans against erythema and formation of endonuclease-sensitive sites in DNA by UVB in human skin. J Invest Dermatoll 1985;85:362-4.

20. Boldeman C, Jansson B, Nilsson B, Wllen H. Sunbed use in Swedish urban adolescents related to behavioral characteristics. Prev Med 1997;26:114.9.

21. Boldeman $\mathrm{C}$. Beitner $\mathrm{H}$, Jansson B, Nilsson B, Ullen $\mathrm{H}$. Sunbed use ir relation to phenotype, erythema, sunscreen use and skin type. Br J Dermatol 1996;135:712-6.

22. Daxecker F. Blumthater M, Ambach W. Keratitis solaris and sunbeds. Ophthalmologica 1995:209:329-30.

23. Peak MJ, Peak IC. Carnes BA. Induction of direct and indirect single-strand breaks in human cell DNA by far- and near-ultraviolet radiations: action spectrums and mechanisms. Photochem Photobiol 1987:84:9103-7. 
24. Tomaletti $\$$, Pfeifer GP. Slow repair of pyrimidine dimers af p53 mutation hotspots in skin cancer. Science 1994:263:1436-8.

25. Ziegler A, Jonason AS, Leffel DI, et al. Sunburn and p53 in the onset of skin cancer. Nature 1994;372:773-6.

26. Kraemer K.H. Sunlight and skin cancer: Another link revealed. Proc Natl Acad Sci USA $1997 ; 94: 11-14$

27. Nataraj A.J, Wolf P, Cerroni L, Ananthaswamy HN. P53 mutations in squanous cell carcinomas from psoriasis patients treated with psoralen + UVA (PUVA). J Invest Dermatol 1997;109:23843.

28. Kligman LH, Akin FJ, Kligman AM. The contributions of UVA and UVB to connective fissue damage in hairless mice. I Invest Dermatol 1985;84:272-6.

29. Forbes PD. Relative effectiveness of UVA and UVB for photocarcinogenesis. In: The biological effects of UVA radiation. Urbach F, Gange RW, eds. New York: Praeger Publishers, USA, 1986.

30. Berg RJW, de Giraijl FR, van der Leun JC. Interaction between ultraviolet $A$ and ultraviolet-B radiations in skin cancer induction in hairless mice. Cancer Res 1993:53:4212-7.

31. De Gruijl FR, Forbes PD. UV-induced skin cancer in a hairless mouse model. Biot:ssays $1995 ; 17: 651-60$.

32. Spencer JM, Amonette RA. Indoor tannning: risks, benefits, and future trends. J Am Acad Dermatol 1995:33;288-98.

33. Lever LR, Lawrence CM. Nonmelanoma skin cancer associated with use of a tarning bed. $N$ Eng J Med 1995;332:1450-1.

34. Westerdahl $J$, Olsson $H$, Masbaick $A$, et al. Use of sunbeds or sunlamps and malignant melanoma in Southern Sweden. Am J Epidemiol 1994;140:69 1-9.

35. Autier $\mathrm{P}$, Dore JF, Lejune $\mathrm{F}$, et al. Cutaneous malignant melanoma and exposure to sunlamp or sunbeds: an EORTC multicenter case-control study in Belgium, France and Germany. Im J Cancer 1993;58:809-13.

36. de Gruijl FR, Sterenborg H.ICM, Forbes PD, et al. Wavellength dependence of skin cancer induction by ultraviolet irradiation in albino hairless mice. Cancer Res 1993;53:53-60. 

Chapter 9

\section{General Discussion}


The incidence of basal cell carcinoma ( $\mathrm{BCC}$ ) is increasing at a phenomenal rate, with a current estimated annual incidence in The Netherlands of more than 29.000 cases. The incidence of skin cancer may have increased due to changes in sumbathing behavior, and aging and can be further due to a decrease in stratospheric ozone. Frequent exposure to ultraviolet radiation (UVR), fair skin, and reduced immunity, possibly related to aging, are the major risk factors of $\mathrm{BCC}$.

The two ways to reduce morbidity (and the rare event of mortality due to this tumor), are improvement of therapy and secondly, even more important: prevention. This thesis is about these two items.

In summary, the cause of $\mathrm{BCC}$ is multifactorial and complex. Knowledge relating to BCC pathogenesis will probably become better understood in the near future.

Mutations in the p53 gene have been detected in $\mathrm{BCC}$ (and squamous cell carcinoma), although the absolute rates of mutation vary between $10 \%$ and $90 \%$ in the various studies. The mutations tend to cluster in "hot spots" along the p53 gene that represent sites of inefficient repair of pyrimidine dimers. The pattern of mutations, with $\mathrm{C} \rightarrow \mathrm{T}$ and $\mathrm{CC} \rightarrow \mathrm{T} T$ base changes predominating, reflects the role of UVR induced DNA damage in the pathogenesis. Whether p53 mutations occur as an early event or a late event of carcinogenesis remains unclear. It may be difficult to clarify this, because the majority of $\mathrm{BCC}$ do not arise from precursor lesions but rather appear de novo.

Recently, however, it has been shown that p53 accumulation is detectable in the epidermis adjacent to $B C C$ in chronically sun-exposed epidermis. Studies suggest that $\mathrm{BCC}$ commonly progress through inactivation of a single p53 allele, although others lind mutations on both alleles.

The gene for Nevoid Basal Cell Carcinoma Syndrome (NBCCS) was recently cloned. This gene, PATCHED, is mutated in BCC of patients with NBCCS as well as in sporadic BCC, and inactivation of this gene is probably a necessary, if not sufficient, step for BCC.

In each case of $\mathrm{BCC}$ characteristics such as tumor history (previous skin cancer, first primary tumor, recurrent tumor, multiple primary tumors at separate sites), histologic subtype, size, anatomic location, patient age, previous therapy, and other medical problems have to be taken into account when determining the optimal treatment plan. Despite the relatively benign nature of $\mathrm{BCC}$ rising incidence rates in an aging population will result in increased medical costs, morbidity, and even mortality.

It is important for dermatologists and surgeons to become familiar with all modalities, surgical as well as nonsurgical, that are used to treat this skin cancer.

Mohs Micrographic Surgery (MMS) is a surgical technique that has been modified and refined over a period of 60 years. This MMS enables the surgeon to attain the highest possible cure rate for $\mathrm{BCC}$, while preserving normal (skin) tissue. In Chapter 3 in this thesis, the main indications for MMS and the pros and cons of MMS are discussed. Undoubtedly, MMS is an important factor in reducing morbidity due to $\mathrm{BCC}$, but it should be kept in mind that prevention is even better in doing so. 
Because UVR exposure is involved in most of the $\mathrm{BCC}$ cases. the key to reducing the number of these skin cancers is through prevention, mainly by reducing exposure to sunlight/UVR and by further exploration of possible chemopreventive agents.

This discussion highlights prevention with sumscreens, protective clothing, and education.

UVR is divided into three spectra: UVC (200 to $280 \mathrm{~nm})$, UVB (280 to $315 \mathrm{~nm})$ and UVA $(315-400 \mathrm{~nm})$. UVC radiation fails to reach the earth's surface because of absorption by the ozone layer.

In addition to the sun, there are some man-made sources of UV exposure. They include the widely used tanning lamps. More and more evidence is accumulating about their hazardous effects on human skin (including the induction of NMSC and even melanoma skin cancer).

Both UVA and UVB radiation affect the skin, causing erythema, pigmentation and DNA damage. Sumburn is erythema that becomes obvious soon after UVR exposure and reaches a maximum at 24 to 36 hours afterwards. It usually resolves in 3 to 5 days. Histologically, sunburn is marked by intracellular edema, and the development of "sunburn cells". Chronic effects of UVR exposure include photoaging and photocarcinogenesis. UVB and UVA are able to damage DNA. Therefore in reducing UV exposure, broad-spectrum coverage against UVB as well as UVA is necessary. Some sunscreens ensure this total protection and consumers need to be educated to pay attention to sunscreen ingredients to make sure that they contain an active ingredient, that blocks UVA (short and long UVA) and UVB. The SPF (sun protection factor) on sunscreens and the currently used numbering system, may not reflect accurately the DNA protective properties of the product. A DNA-damage marker like p53 provides a more rational approach to optimal skin protection. We propose to express the DNAprotective properties of sunscreens as the degree to which they prevent DNA-damage and wild-type p53 expression: a DNA-protection-factor.

Mutation of p53 may produce a possible dominant protooncogene able to add malignant potential to tumors. This somcalled "gain of function" $p 53$ mutation could be the predominant mechanism of progression for BCC. Alternatively, the well-established tumor suppressing function of $p 53$ could be diminished by inactivation of a single allele. It has been suggested that chronic UV exposure is responsible for accumulation of p53 mutations and thus for late age BCC appearance, whereas acute UV exposure in childhood and adolescence leads to carly skin cancer development in genetically susceptible individuals via a p53-independent pathway.

It is conceivable that p53-based gene therapy may one day be used in the treatment of skin tumors, given the key role of $p 53$ in regulating cell division and differentiation.

Earlier studies demonstrated that sunscreens are not always applied properly. To obtain maximum benefit, the application of $2 \mathrm{mg}$ of sunscreen per centimeter squared is recommended. Most people do not apply this amount: I mg of sunscreen applied per centimeter squared, results in an SPF of only hall of the factor on the label"

If the skin gets wet, sunscreens may lose their protective abillity and must be reapplied more often (every hour instead of every two hours). 
UVR intensity is greatest during the hours between 10:00 a.m. and 4:00 p.m. UVR intensity varies with the season. UVR intensity increases in the summer months and decreases during the winter. This is due to the lower angle of contact between the earth and the sun's radiation during the winter months.

During the summer, when the sun is more directly overhead with a greater contact angle "the UV-light has a shorter path to the earth's surface. Seasonal fluctuations in the ozone layer also affect UVR intensity.

Elevation is also important: every 1000 foot increase in altitude brings with it a $4 \%$ increase in UVB exposure. Many surfaces, including snow and sand, are efficient reflectors of UVR. Snow, for instance, can reflect as much as $85 \%$ of UVR making it especially important that skiers wear a sunscreen.

It is necessary to photoprotect persons at an early age to prevent future skin cancers (and photoaging). Sunscreens with a SPF of 15 or higher should be applied to children aged 6 months and older. There is no reason for young children less than 6 months old, to have sun exposure requiring sunscreen protection!

Regular sunscreen use reduces the chance of developing actinic keratosis and NMSC. Sunscreens are an important tool in skin cancer prevention, in particular for patients who have a history of skin cancer (for immunosuppressed people, NBCCS patients, etc) and for people who work outside or participate in outdoor sports.

Clothing provides UVR protection, although this depends on the fabric. When the cloth becomes wet, the screening value of the garment decreases. In the last few years UVRprotective fabrics have been manufactured. An exciting innovation has been the use of an ultraviolet absorber which dramatically improves a garment's rating. Australia is about to have the world's first standard for rating sun-protective clothing: the Ultraviolet Protection Factor (UPF). This is necessary because apparently some fabrics offer less protection than a sunscreen with SPF 15 ! Hats or caps (with a wide brim) provide excellent protection to the most common skin cancer site: the face.

Skin cancer prevention is not possible without adequate education. In planning educational programs, current beliefs have to be evaluated.

The old belief that "tans are healthy" should be replaced by the thought that "tanning is a health risk".

It is known that women have more knowledge than man about the potentially harmful effects of sun exposure, but they are also more likely to sunbathe and to frequent tanning beds.

Despite the fact that significant sun damage to the skin occurs during childhood and early adolescence, most children and teenagers do not use sunscreens.

The bottom line is that physicians must emphasize education about skin cancer, tanning, skin cancer prevention and sunscreen use, and this should be directed especially at children, adolescents and all skin cancer patients. 
Chapter 10

\section{Samenvatting}




\section{Hoofdsiuk I}

Het $\mathrm{BCC}$ is de meest voorkomende vorm van huidkanker en omvat meer dan $80 \%$ van alle huidkankergevallen. In dit proefschrift worden twee aspecten van de strijd tegen het BCC belicht: optimale behandeling en preventie.

In het eerste hoofdstuk wordt de etiologie, kliniek, histopathologie en behandeling van het $\mathrm{BCC}$ beschreven. Het BCC is de meest voorkomende vorm van (huid-jkanker bij de blanke mens. Er bestaat een grote hoeveelheid bewijsmateriaal dat het BCC geassocieerd is met blootstelling aan UV-straling. Het aantal gevallen van BCC (zoals ook SCC en maligne melanomen) neemt bovendien toe, niet alleen in Nederland, maar wereldwijd. Zo was thet aantal BCC in 1994 nog zo'n 18.000 in Nederland. In 1998 wordt dit aantal op zo'n 29.000 geschat. Deze toename is toe te schrijven aan o.a. een vergrijzing van de bevolking, een veranderd "zongedrag" (mensen kunnen meer vrije tijd in de zon doorbrengen, een gebruinde huid is populair, lange vakanties naar zonnige streken, gebruik van zonnebanken etc.), en mogelijk ook door een afname van de ozonlaag. Het is bekend dat $\mathrm{BCC}$ vaker voorkomen in geografische gebieden met meer en intenser zonlicht, op gebieden van de huid die veelvuldig blootstaan aan zonlicht, en bij mensen met een zeer lichte huid die makkelijk verbrand. Mensen die beroepsmatig veel buiten werken en mensen met veel buiten-activiteiten hebben een grotere kans op het verkrijgen van niet-melanoma huidkanker. Het $\mathrm{BCC}$ is een maligne tumor die slechts sporadisch metastaseert, maar die, wanneer niet afdoende wordt behandeld, aanleiding kan geven tot grote morbiditeit. Bovendien is de kans op het ontwikkelen van meerdere $\mathrm{BCC}$ of andere huidmaligniteiten groot. De huid van een patiënt met een $\mathrm{BCC}$ moet regelmatig worden gë̈nspecteerd op recidieven of nieuwe maligniteiten.

Tips voor huidkanker-preventie:

-Beperk zon-expositie, met name tussen 10 uur 's ochtends en 4 uur in de middag. -Gebruik een zonnebrandcrème met een hoge beschermingsfactor, die zowel UVA als UVB filtert

-Draag beschermende kleding zoals een hoed, shirt met lange mouwen, lange broek en een zonnebril.

-Let met name op op het water, op het strand, in de sneeuw en de bergen.

-Gebruik geen zonnebank of gezichtsbruiners.

-Voor kinderen: zorg voor extra bescherming.

\section{Hoofdstuk 2}

Hierin wordt het ontstaan en ontwikkeling van huidkanker en BCC beschreven. Het zogenaamde 'multi-step proces' in de carcinogenese wordt ook voor het $\mathrm{BCC}$ verondersteld. Hierbij speelt enerzijds een genetische aanleg (zoals bij o.a. het Basaalcel nevus syndroom) en anderzijds het ontstaan van mutaties in oncogenen en turnorsuppressor genen (o.a. het 53 gen en het PATCHED gen) een rol.

\section{Hoofdstuk 3}

In dit hoofdstuk wordt de behandeling van het BCC door middel van Mohs Micrografische Chirurgie (MMS) beschreven. De ontwikkeling, de theoretische achtergrond, de indicaties, en de technische uitvoering worden besproken. MMS is met name geschikt 
voor de behandeling van grote $\mathrm{BCC}$ in het gelaat, BCC op een lastige lokalisatie, BCC met een agressief groeipatroon en of recidief BCC. MMS is een chirurgische techniek waarbij een huidtumor laag-voor-laag wordt verwijderd en het gehele excisic-oppervlak microscopisch wordt onderzocht.

Een prospectieve gerandomiseerde studie naar de effecten van MMS is echter noodzakelijk om Mohs" chirurgie (evidence-based) op zijn waarde te kunnen schatlen. In de toekomst zal een steeds grotere patiëntenpopulatie voor deze techniek in aanmerking komen, waardoor de behoefte ontstat aan in Mohs Micrografische Chirurgie ervaren dermato-chirurgen.

\section{Hoofdstuk 4}

In dit hoofdstuk wordt onderzoek beschreven naar het keratine-profiel van BCC: "Niet-agressieve BCC" worden vergeleken met "agressieve, gerecidiveerde BCC". Alle BCC brengen keratine 5, 14 (de "basale cel" keratinen) en 17 tot expressie. In de meer agressieve BCC worden bovendien keratine 8 en 20 (do "eenvoudige keratines") tot expressie gebracht, hetgeen een hogere flexibiliteit van de kankercellen tol gevolg kan hebben. Hierdoor zou kunnen worden verklaard dat juist deze BCC zich verder in de huid kunnen uitbreiden en moeilijker te behandelen zijn.

\section{Hoofdstuk 5}

Epidemiologische en experimentele gegevens wijzen erop dat UVB straling (zonnebrand spectrum, $280-315 \mathrm{~nm}$ ) de belangrijkste golflengte bevat voor de inductie van huidkanker. Vermindering van de ozon in de atmosfeer zal een toename van de hoe-m veelheid UVB straling op aarde en een toename van huidkanker tot gevolg hebben. Mathematische modellen suggereren dat bij iedere $1 \%$ vermindering van de ozonlaag, het aantal gevallen van huidkanker met $2-4 \%$ zal toenemen. De mechanismen via welke UVB huidkanker veroorzaakt zijn: beschadiging van het DNA en haar reparatiesysteem en de veranderingen in het immuun systeem. UVB straling induceert de vorming van pyrimidine dimeren in het DNA. Langgolvig UVA straling beschadigd DNA op een soortgelijke manier en is carcinogeen in dieren. UV straling induceert mutaties in p53 tumor-suppressor genen. Zulke mutaties worden ook gevonden in cen verscheidenheid van huidtumoren. Dit ondersteunt de gedachte wan een etiologische rol voor ultraviolet licht in dit type van veranderingen in tumor-suppressor genen.

Het advies voor UV-protectie is met name van belang voor kinderen, mensen met een "buiten-beroep" en/of buiten-hobby's, en voor mensen met een grotere kans op het ontstaan van huidkanker (zoals o.a. niertransplantatic-patiénten, familieleden van huidkankerpatienten, etc).

\section{Hoofdstuk 6}

Wij onderzochten het beschermend effect van zonnebrandcrème (Zwitsal SPF 10 en Zwitsal SPF 20) op DNA-schade, door middel van deze 553 expressic in huidbiopten, 1 dag na een anderhalf uur durende blootstelling aan zonlicht, op het Scheveningse strand op een zomerse dag.

In alle 25 gezonde vrijwilligers (huidtypes 1-3) trad na onbeschermde expositic aatr zonlicht, een forse stijging van de p53 expressie op in de basale en suprabasale lagen 
van de epidermis. Erytheem werd slechts in 19 van de 25 vrijwilligers gezien. In de 6 vrijwilligers waarbij geen erytheem werd gezien kon wel een forse stijging van de $p 53$ expressie worden aangetoond. De huidmonsters werden onderzocht op de aanwezigheid van p53 (als marker voor DNA-schade) in de opperhuid. De huidmonsters van niet aan zonlicht blootgestelde huid, toonde zeer weinig p53 in de opperhuid. Ook de twee huidmonsters van met zonnebrandcrèmes ingesmeerde huid lieten weinig p53 zien (in de huid beschermd met SPF 10 was iets meer p 53 aantoonbaar dan in de huid beschermd met SPF 20). In de onbeschermde en anderhalf uur aan zonlicht blootgestelde huid was een zeer forse toename aan p53 (als marker voor DNA schade) aantoonbaar. P53, een eiwit dat een belangrijke rol speelt in het reguleren van de celcyclus na DNA-schade, wordt immunohistochemisch aantoonbaar in de epidermis en superficiële dermale fibroblasten van volwassen huid na expositie aan een (erytheern)-inducerende dosis UV-straling. Beide zonnebrandcrèmes boden zowel UV-protectie ten aanzien van het beschermen tegen het optreden van erytheem, alswel DNA-protectie, zoals gemeten in de 553 expressie.

Wij concluderen dat p53 expressie een sensitieve parameter is voor het bepalen van UV-geïnduceerde DNA-schade en dat p53 expressie kan worden toegepast als maat woor de DNA-beschermende werking van zonnebrandcrèmes.

\section{Hoofdstuk 7}

Met behulp van een Solar Simulator, werden bij 12 gezonde vrijwilligers een drietal zonnebrandcrèmes op hun p53-beschermend effect onderzocht. Het betrof SPF 8, 30 en 40 (Roc). Erytheem trad niet in de ingesmeerde huid op, echter wel een lichte stijging van p53-expressie in de met SPF 8 ingesmeerde huid. Onze conclusie is dat de "DNA-bescherming" een betere maat voor de effectiviteit van zonnebrandcrèmes is dan de op dit moment gehanteerde SPF (Sun Protection Factor).

\section{Hoofdstuk 8}

Hierin wordt een onderzoek beschreven waarbij 150 gezonde vrijwilligers een 10 dwagse "zonnekuur" onder een zonnebank volgden. In totaal werden 20 zonnebanken en gezichtsbruiners onderzocht.

Het gebruik van zonnebanken veroorzaakt naast bruining en versnelde huidveroudering ook een toename van p53 expressie/DNA schade. Opvallend was dat er een correlatie was tussen de toegenomen bruining en de toegenomen p53 expressie. Echter vrijwilligers die niet bruinden, vertoonden eveneens een toename van p53 expressie. Aangezien DNA schade een belangrijke schakel is in het ontstaan van huidkanker, zou het gebruik van zonnebanken voor bruining moeten worden ontraden. Dit geldt in het bijzonder voor kinderen, adolescenten, huidkanker-patiënten, patiënten met een hoge kans op het krijgen van huidmaligniteiten (NBCCS-patiënten, niertransplantatiepatiènten, etc) en mensen met een verhoogde blootstelling aan zonlicht. 


\section{Dankwoord}

Allereerst gaat mijn dank uit naar mijn moeder, voor de steun die zij samen met mijn vader heeft gegeven en voor de dingen die zij samen voor mijn opleiding hebben gedaan en gelaten.

Prof. Neumann, wil ik bedanken voor het in mij gestelde vertrouwen om zowel de opleiding tot dermatoloog als tot Mohs chirurg (dermato-chirurg) in Maastricht te mogen voltooien en voor de vrijheid die ik kreeg om dit promotie-onderzoek op mijn manier vorm te geven.

Rick Hoekzema, mijn co-promotor, dank ik voor de opbouwende kritiek en de tegelijkertijd gezellige "Amsterdamse" koffie-pauzes.

Prof. Ramaekers, wil ik hartelijk danken voor zijn bijdrage aan de diverse hoofdstukken in dit proefschrift.

De leden van de beoordelingscommissie dank ik voor hun bijdrage aan dit proefschrift.

Mijn collega's (verpleging, artsen, secretariaat, polikliniekmedewerkers, medewerkers van de afdeling moleculaire celbiologie, pathologie, etc.), ex-collega's en studenten (Nicole Smeets, Hanneke Engwerda, Marjoes Schuckman, Martijn van der Scheur en Philo Werner), dank ik voor hun bereidwilligheid om mee te werken aan dit onderzoek (zowel als vrijwilliger, als mede-onderzoeker, als hulp bij het afnemen van de biopten, maar ook bij het opbouwen van de zonnebanken, etc., etc.).

Uiteraard dank ik alle vrijwilligers die stukjes bil voor dit onderzoek wilden afstaan.

Verder dank ik mijn broers en Bart, Jack en Ger Legeland voor de snelle en professionele verbouwing van een oude bouwkeet tot 'sunbed-research-center'.

Anneke, dank je wel woor je gezelligheid en creativiteit.

Ton van Heeswijk dank ik voor zijn bijdrage aan de Engelse lay-out van dit boekje.

Dan mijn paranimfen, Judith Ostertag en Marc Verhaegh, die ik dank voor hun hulp bij deze promotie. Marc, jou dank ik bovendien in het bijzonder voor de manier warop jij leiding geeft aan de opleiding tot Mohs-chirurg.

Roger, dank je wel, want jij weet als geen ander welke steun ik op welk moment nodig heb. 


\section{Curriculum vitae}

Gertruud Krekels werd op 28 november 1965 te Bladel geborem. Na het behalen van het VWO-diploma in 1984 (Pius-X-College te Bladel), werd gestart met de studie Geneeskunde aan het Rijks Universitair Centrum Antwerpen (RUCA). In 1986 volgde inloting voor de studie Geneeskunde in Nederland. Vanaf oktober 1986 tot februari 1993 werd de opleiding tot basisarts gevolgd aan de Universiteit van Amsterdam (AMC). Vervolgens werkte ze tot 31-12-93 als poortarts in het Sint Jozef Ziekenhuis te Veghel. Sinds 1-1-94 is zij werkzaam bij de vakgroep Dermatologie in het AZM. Per 1-7-97 werd voldaan aan de registratie voor Mohs-chirurg. Per 1 april 2000 zal de opleiding tot dermatoloog worden afgerond. Voor een deel van het promotie-onderzoek ontving zij in 1996 te Athene, de European Award in Photodermatology. 